[This document contains the author's accepted manuscript. For the publisher's version, see the link in the header of this document.]

\title{
Sentiment and Stock Returns: The SAD Anomaly Revisited
}

\author{
Felix Meschke \\ University of Kansas - Finance Area \\ Patrick J. Kelly \\ University of South Florida - Department of Finance; New Economic School (NES)
}

\section{Paper citation:}

Patrick J. Kelly, Felix Meschke, Sentiment and stock returns: The SAD anomaly revisited, Journal of Banking \& Finance, Volume 34, Issue 6, June 2010, Pages 1308-1326, ISSN 0378-4266,

10.1016/j.jbankfin.2009.11.027.

\section{Keywords:}

Asset pricing, market efficiency, behavioral finance, depression, seasonality, predictability, investor behavior, Seasonal Affective Disorder,SAD

\begin{abstract}
:
Widely-cited research by Kamstra et al. (2003) argues that changes in mood resulting from Seasonal Affective Disorder (SAD) drive changes in investor risk aversion and cause seasonal patterns in aggregate stock returns around the world. In this paper we reexamine the so-called SAD effect by replicating and extending Kamstra et al. (2003). We study the psychological underpinnings of the SAD hypothesis and show that the time-series predictions of the SAD model do not correspond to the seasonal patterns in depression found in the general population. We also investigate the cross-sectional prediction that SAD has a greater effect on stock markets in countries where SAD is more prevalent and find no relation between the prevalence of SAD and stock returns. Finally, we document that the SAD effect is mechanically driven by an overlapping dummy-variable specification and higher returns around the turn of the year.
\end{abstract}




\title{
Sentiment and stock returns: The SAD anomaly revisited
}

\author{
Patrick Kelly \\ Department of Finance \\ University of South Florida \\ 4202 E. Fowler Ave, BSN 3403 \\ Tampa, FL 33620, USA \\ (813) 974-6358 \\ patrick@usf.edu
}

\author{
Felix Meschke \\ Carlson School of Management \\ University of Minnesota \\ $32119^{\text {th }}$ Avenue South, Room 3-122 \\ Minneapolis, MN 55455, USA \\ 612-626-2583 \\ meschke@umn.edu
}

Forthcoming, Journal of Banking \& Finance

We are grateful to Min Ahn, Michael Hertzel, Vincent Kelly, Laura Lindsey, Stewart Low, Spencer Martin, Federico Nardari, Gregory Noronha, Michael Pinegar, Gareth Thomas and seminar participants at Arizona State University and the 2004 Financial Management Association meetings for helpful comments and suggestions. We are also grateful to an anonymous referee for many insightful comments and suggestions. We thank Lisa Kramer for graciously providing the data used in Kamstra et al. (2003) and Mikael Bergbrant, Truong Duong and Xi Liu for excellent research assistance. 


\title{
Sentiment and stock returns: The SAD anomaly revisited
}

\begin{abstract}
Widely-cited research by Kamstra et al. (2003) argues that changes in mood resulting from Seasonal Affective Disorder (SAD) drive changes in investor risk aversion and cause seasonal patterns in aggregate stock returns around the world. In this paper we reexamine the so-called SAD effect by replicating and extending Kamstra et al. (2003). We study the psychological underpinnings of the SAD hypothesis and show that the time-series predictions of the SAD model do not correspond to the seasonal patterns in depression found in the general population. We also investigate the cross-sectional prediction that SAD has a greater effect on stock markets in countries where SAD is more prevalent and find no relation between the prevalence of SAD and stock returns. Finally, we document that the SAD effect is mechanically driven by an overlapping dummy-variable specification and higher returns around the turn of the year.
\end{abstract}

JEL classification: G14; G12

Keywords: Asset pricing; Market efficiency; Behavioral finance; Seasonality; Predictability; Investor behavior; Seasonal affective disorder; SAD 


\section{Introduction}

Seasonality in international stock returns has been known for decades (Rozeff and Kinney, 1976; Gultekin and Gultekin, 1983). As Figure 1 shows, the average monthly global stock returns are negative in September and extremely positive around the turn of the year.

Do these seasonalities in stock returns represent an exploitable violation of the efficient market hypothesis? Not if they are pure coincidence. In other words these seasonalities may be apparent ex post, but investors could not have profited because they did not know about them ex ante (Wu and Zhang, 2009). If they are predictable ex ante, stock-return seasonals constitute an important challenge to the efficient market hypothesis because rational traders should be able to exploit them for large economic gains. Not all traders are rational, however. There is a large literature in financial economics documenting that sentiment affects investor behavior [Kahneman and Tversky (1979), Odean (1998a, 1998b, 1999), Barber and Odean (2000, 2001, 2002), Grinblatt and Keloharju (2000, 2001a, 2001b, 2008), Lo, Repin, and Steenbarger (2005)]. It therefore comes as no surprise that financial researchers investigate whether predictable patterns in investor behavior cause predictable patterns in stock returns.

An influential article in the American Economic Review by Kamstra, Kramer and Levi (2003) (hereafter, KKL2003) argues that a psychological condition called Seasonal Affective Disorder (SAD) drives changes in the risk aversion of the marginal investor and causes the seasonal patterns in stock return displayed in Figure 1. SAD is a mood disorder in which individuals suffer from depression as a result of fewer daylight hours in 
fall and winter. ${ }^{1}$ KKL2003 hypothesizes that the onset of seasonal depression results in greater risk aversion in the affected subset of investors, who therefore sell stock, decreasing prices in the fall as the days get shorter. As the days lengthen and the mood of these seasonally depressed investors improves in winter, they buy stock, driving up prices. Expected returns as predicted by the SAD model are plotted in Figure 2 for several markets. KKL2003 examines stock index returns from nine countries (12 indices) and reports statistically significant negative coefficients on a fall dummy and significant positive coefficients on a SAD measure ${ }^{2}$ for six out of nine countries.

In this paper we critically reexamine KKL2003. First, our survey of the psychological literature shows that the seasonality of the model-predicted returns (depicted in Figure 2) does not correspond to patterns of seasonal depression in the general population. Second, we replicate the original KKL2003 study and extend the sample from 9 countries (12 indices) to 36 countries (47 indices). Third, we use the extended sample to see whether there are more pronounced stock market effects due to SAD in countries where the marginal trader is more likely to be afflicted by SAD. KKL2003 uses latitude to proxy for this likelihood because previous research has shown that SAD is more prevalent at higher latitudes. We examine the link between SAD prevalence and the magnitude of seasonal returns more directly and find that there is no economically meaningful relation between the magnitude of the fall and SAD coefficients and the prevalence of SAD.

Finally, we show that the statistical significance of the fall dummy is largely driven by a de facto overlapping dummy-variable specification in which the SAD

\footnotetext{
${ }^{1}$ For an overview of SAD, see Partonen and Lönnqvist (1998).

2 The KKL2003 SAD measure is an interaction term of a dummy variable equal to one for all days during fall and winter and a normalized measure of the length of the night. See Section 4 for details.
} 
measure, a highly persistent level variable, acts as a fall-winter dummy. To illustrate, consider if returns were quite large during winter but in fall no different from spring and summer. In a specification with a fall and a fall-winter dummy, the fall-winter dummy would capture the positive winter returns and implicitly attribute them to the entire period from fall to winter, while the intercept captures average returns in spring and summer. Because fall returns are no different from spring and summer, the coefficient on the fall dummy would have to be of equal magnitude and opposite sign to the fall-winter coefficient. Hence, the overlap between the two dummies would mechanically induce statistical significance where a properly specified model would find none. We break the SAD variable into two components, fall SAD and winter SAD and find that once the overlapping dummy specification is eliminated, the significance of the fall dummy goes away.

While there is a large and growing literature that uses KKL2003 to motivate their research, several other studies are critical of the SAD hypothesis. Goetzmann and Zhu (2005) examines investor trading activity in five major U.S. cities from January 1991 to November 1996 and concludes that their "results offer little support for the argument that investor behaviour is influenced by seasonality in the length of daytime hours” (p.566). Jacobsen and Visaltanachoti (2006) studies seasonalities in U.S. sectors, and Joshi and Bhattarai (2007) examines the effects of cloud cover, temperature and the KKL2003 SAD measure on the Nepalese stock market and reports that only cloud cover is positively correlated with daily stock returns. Edmans, García, and Norli (2007) points out that KKL2003 relies on a continuous proxy for investor mood which has a lower signal-to-noise ratio in returns than studies that employ an event approach. 
We owe the greatest intellectual debt to Jacobsen and Marquering (2008, 2009) which reexamine the evidence which links SAD and temperature induced changes in mood to stock returns. They point out that it is difficult to differentiate between the various explanations for stock market seasonalities and show that neither the SAD nor temperature arguments are robust with respect to the countries' latitude. They conclude "that it is simply not enough to link temperature and SAD directly to stock returns on the assumption that these variables affect mood and therefore affect stock returns” (p. 539) and call for further research on this topic. We answer their call by identifying important weaknesses in the development and econometric implementation of the SAD hypothesis.

While our econometric critique is specific to KKL2003's proposed SAD effect, our review of the medical and psychological evidence has broader implications for behavioral studies in finance and economics. Specifically, our critical reexamination illustrates that an association between sentiment-affecting events and stock prices is not sufficient to credibly establish a causal link between the two.

\section{Medical basis of the hypothesis development}

In this section we critically review the psychological underpinnings of KKL2003’s SAD hypothesis. To understand the psychological issues that this hypothesis raises, imagine that a person named Sadie represents the marginal investor of a sizable group of SAD-afflicted investors, while Sunny represents the marginal investor of the remaining population that is not affected by SAD. As Sadie experiences increasing symptoms of seasonal depression, she becomes more risk-averse and sells off part of her stock holdings to Sunny. Sunny is only willing to increase his exposure to stocks if the 
expected return increases by some amount. As the days lengthen again and Sadie's depressive symptoms subside, she buys back stocks from Sunny and her demand decreases expected stock returns. In short, aggregate stock prices fall as Sadie sells off her stock holdings to Sunny and rise as she buys stocks back from him.

Since Sunny is a rational investor and perfectly willing to adjust his portfolio allocation for the right price, no further insights from the psychological literature are needed to understand him. The same cannot be said for Sadie. In fact, this hypothesized interaction between Sadie and Sunny raises a number of questions about her: do Sadie's depressive symptoms indeed translate into heightened financial risk aversion? Does depression increase or decrease her propensity to take action to adjust her portfolio allocation? When does Sadie start selling her stocks? Does she sell most of them right away, or does she trade out of them over time as her symptoms worsen?

In principle, all of these questions lend themselves to empirical investigation. With day-by-day records of investors' psychological states, their trading and their portfolio holdings, we could directly examine how seasonal changes in depression translate into seasonal variations in portfolio holdings. A good example for this line of inquiry is Grinblatt and Keloharju (2008), which examines how sensation seeking and overconfidence affect the tendency of investors to trade stocks. They do so by matching results from a psychological test given to all Finnish males by the Finnish Armed Forces with portfolios and trading records (1995-2002) of all household investors domiciled in Finland.

KKL2003 does not derive the interaction of Sadie and Sunny from records of traders who are either afflicted or unaffected by SAD but instead turns to the 
psychological literature for guidance in developing its hypotheses. This is laudable. Instead of just suggesting an ad hoc explanation of the seasonality in international stock returns, KKL2003 restricts itself to psychological theories of time-varying mood changes that have been developed without the consideration of stock return patterns. As we show below, the problem of grounding KKL2003's SAD hypothesis soundly in the psychological literature stems from the fact that the literature doesn't address directly the questions listed above. By answering them nevertheless, KKL2003 makes several crucial assumptions that are either not established or are inconsistent with the psychological literature. The remainder of this section is structured around the questions listed above. For each question, we survey the related psychological literature and examine how KKL2003 relates to this literature.

\subsection{Do Sadie's depressive symptoms translate into heightened financial risk aversion?}

The medical literature does not directly address whether seasonal variation in depression causes time-varying risk aversion. But it does examine whether depressed individuals are more risk averse in their financial decisions. Unfortunately, the evidence here is quite mixed: Smoski et al. (2008) finds that depressed individuals take less risky gambles than non-depressed individuals. By contrast Clark, et al. (2001) and Hockey (2000) find no such association between mood and risk-taking behavior. Raghunathan and Pham (1999) finds that individuals who are induced to be sad (i.e., unhappy) actually choose riskier gambles over safer ones.

In earlier studies Zuckerman (1979, 1984, 1994) and Carton (1992) document that depressed individuals score low on surveys measuring "sensation seeking”, which is 
defined as "the need for varied, novel, and complex sensation and experiences and the willingness to take physical and social risks for the sake of such experiences” (Zuckerman, 1979, p.10).

KKL2003 equates sensation seeking and financial risk aversion; however, this link is contested. On the one hand, a study by Wong and Carducci (1991) shows that college students with lower sensation-seeking scores indicate more risk-averse preferences when asked about hypothetical financial choices: such as buying stocks, bonds, certificates of deposit, and a house. On the other hand, Morse (1998) finds no cross-sectional relationship between sensation seeking and actual investment choices. This is consistent with the findings of Horvath and Zuckerman (1993), which examines the cross-sectional relationship between sensation seeking and four risk factors among college students. They find that sensation seeking "was negatively and significantly correlated with own risk appraisal for all of the risk areas except financial risk” (p.45) and argue: "Financial risk taking may be a special type not as highly related to the more general sensation seeking trait” (p.49).

In summary, no time-series evidence in the medical literature relates changes in depression to changes in risk aversion. While the medical literature documents crosssectional evidence of a link between depression and sensation seeking across individuals, it only provides mixed evidence regarding the effect of depression on financial risk aversion. 


\subsection{Do Sadie's depressive symptoms lead her to adjust her portfolio allocation?}

The previous section reported studies that link depression to low sensation seeking, and, by some accounts, to greater financial risk aversion across individuals. But the SAD hypothesis requires that time-series changes in mood lead to time-series changes in financial risk aversion, which, in turn, motivates actual trading.

While it seems intuitive to extrapolate from cross-sectional studies linking heightened depression to greater risk aversion to time-series behavior, the medical literature provides no such evidence. Surprisingly, there is some evidence to the contrary: Carton, Morand, Bungenera, and Jouvent (1995) finds that treatment for depression, among non-seasonally depressed individuals, alleviates depressive symptoms, but does not affect the sensation-seeking propensity of individuals. Hence, even if sensation seeking were to proxy for financial risk aversion Carton et al., (1995) suggests the possibility that changes in depression do not necessarily translate to changes in financial risk aversion.

Changes in depression may not spur sufferers to act either. Eisenberg, Baron, and Seligman (1998) finds that "more depressive symptoms and more anxiety went with less tendency to act.” In addition, Grinblatt and Keloharju (2008) finds that investors with lower sensation-seeking propensity are less likely to trade. In summary, the medical literature does not provide much evidence for the notion that Sadie adjusts her stock portfolio in response to seasonal changes in her depression. 
2.3. When does Sadie start selling her stocks and when does she buy them back?

KKL2003 proposes that

the depressive effects of SAD and hence risk aversion may be asymmetric about winter solstice. Thus two dates symmetric about winter solstice have the same length of night but possibly different expected returns. [KKL2003] anticipate[s] seeing unusually low returns before winter solstice and abnormally high returns following winter solstice... [as] days begin to lengthen and SAD-affected individuals begin resuming their risky holdings. (p. 326)

According to this conjecture, stock returns in the Northern hemisphere are expected to rise after December 21. KKL2003 cites studies by Palinkas et al. (1996) and Palinkas and Houseal (2000) to support their argument for an asymmetric SAD effect. Both studies examine seasonal variation in mood and behavior in "self-selected, psychologically screened, and highly motivated” men and women who spent the 1991 austral winter at three different research stations in Antarctica. Personnel at two of the three stations have depression measures which are highest during the austral fall and lower in winter. KKL2003 interprets the high depression in fall, followed by low depression in winter, as support for an asymmetric SAD effect, which predicts low stock returns in fall followed by high stock returns in winter.

Palinkas and Houseal (2000) points out that its findings are most likely samplespecific and should not be extrapolated to the population at large. The paper notes that the one station with high and relatively constant depression measures experiences mid-winter fly-in, when new supplies are delivered and station personnel are changed. Palinkas and Houseal (2000) argues that "the end of isolation is associated with anxiety and tension related to the uncertainty of returning home and anger with replacement personnel for disturbing station routines, violating winter-over group norms, and adding to the 
increased amount of work and environmental stimulation. Palinkas and Houseal (2000, p.137)” Because the two stations with higher depression scores during fall also have flyins during fall, it is difficult to disentangle the depressive effects of seasonal changes and disruption in station routine. Palinkas et al. (1996, p.533) explicitly cautions:

Prolonged darkness is only one of the factors contributing to depressed mood during the austral winter in Antarctica [citation omitted]. Station personnel must also contend with prolonged separation from family and friends, the lack of privacy in cramped quarters, and boredom caused by lack of environmental and social stimulation. Thus, caution should be exercised when attempting to generalize the results to the general population.

In fact, studies that draw a more representative sample from the general population suggest that the seasonal patterns in mood do not follow the patterns of depression found in the over-winter Antarctic researchers. Kasper et al. (1989) conducts a telephone survey of 416 randomly selected households in Montgomery County, Maryland, a suburb of Washington, D.C., to examine seasonal patterns in mood. In contrast to the midwinter remission of depression found in the Antarctic studies, they report "an obvious peak, with $43.2 \%$ of survey subjects feeling worst in January and/or February.”3 KKL2003 assumes that these depressive effects subside and returns increase immediately following December 21. One concern might be that neither the Antarctic study nor the Montgomery County study is limited to SAD-afflicted individuals. Yet Lam (1998) studies 454 SAD-afflicted patients in Vancouver on a monthly basis and finds that "[f]or most patients, the usual onset of an episode is in October, and the typical offset is

\footnotetext{
${ }^{3}$ Other articles documenting the patterns of depression severity are Mersch (2001), Schlager et al. (1993), Terman et al. (1989), Thompson (1989), and Wirz-Justice et al. (1989).
} 
in April" (page. 63), which is inconsistent with an increase in returns immediately following December 21, due to relief from depression. ${ }^{4}$

To summarize, KKL2003’s SAD hypothesis requires that time-varying depression causes time-varying risk aversion and that individuals start feeling better following the winter solstice at the end of December. In contrast, our review of the medical literature reveals that no time-series evidence relates changes in depression to changes in risk aversion, and that the seasonal variation in mood reaches its lowest point in January and February, precisely when KKL2003 predicts high returns due to subsiding depression and when the typical person afflicted with SAD is months away from relief. Hence, KKL2003 effectively uses financial markets to test the effects of a behavioral hypothesis which is not established in the medical literature through more direct methods. There may arguably be a place for ad hoc models in economics as long as they are empirically falsifiable (Popper, 1934). In the remaining sections, therefore, we reexamine the econometric findings that support the SAD hypothesis.

\section{Data}

KKL2003 uses data from 9 countries (12 indices). We extend the sample to 36 countries (47 indices). All indices used in this study are daily price or return indices from Datastream International except the equal- and value-weighted NYSE, AMEX, and NASDAQ exchange returns without distributions and the S\&P 500 index, which are from the Center for Research in Security Prices (CRSP). For every country we select the longest return or price index. We chose the return index, which includes dividends, over

\footnotetext{
${ }^{4}$ Kamstra, Kramer, and Levi (2007) propose an alternate version of the SAD measure to address this very concern. We discuss this new measure briefly in section 6.3.
} 
the price index when they have the same coverage. For the UK, New Zealand, Australia, and Sweden the longest series is not the series used in KKL2003. To facilitate comparison we add the FTSE 100, New Zealand Cap 40, Australia - All Ordinaries, Sweden Veckans Affärer and all major U.S. indices listed on CRSP.

We obtain hourly temperature (in Celsius), cloud cover (in percent of sky overcast), and precipitation (in millimeters) from the National Atmospheric and Oceanic Administration's National Climate Data Center Global Hourly Surface Data (NOAA). Chang at al. (2008) finds an association between intraday stock returns and weather variables. For this reason we follow Hirshleifer and Shumway (2003) and construct daily weather variables by averaging all hourly weather observations between the period from 6 a.m. to 4 p.m., local time.

Table 1 describes the choice of index, the latitude of the city in which the exchange is located, the start year of each series, the first year from which all weather data are available on a daily basis, the percentage of days with returns and no missing weather data, and the first day of the country's tax year. All series end in 2008, with the following exceptions: Sweden's Veckans Affärer ends in 2003, the New Zealand Capital 40 ends in 2004, and the Amex, NASDAQ, and NYSE series end in 2007. Taiwan is missing daily precipitation data past 2001.

\section{Econometric reexamination of the SAD effect}

We begin our reexamination by heeding the clarion call of Hamermesh (2007) and replicate KKL2003. Lisa Kramer very graciously provided us with the data used in 
KKL2003. We replicate the model which tests the SAD hypothesis via the following regression:

$$
\begin{gathered}
r_{i, t}=\alpha_{i}+\rho_{1, i} r_{i, t-1}+\rho_{2, i} r_{i, t-2}+\beta_{i, \text { fall }} D_{i, t}^{\text {fall }}+\beta_{i, S A D} S A D+\beta_{i, \text { Monday }} D_{i, t}^{\text {Monday }}+ \\
\beta_{i, t a x} D_{i, t}^{\text {tax }}+\beta_{i, \text { Cloud }} \text { Cloud }_{i}+\beta_{i, \text { Precip }_{\text {Precip }}}+\beta_{i, \text { Temp }} \text { Temp }_{i}+\varepsilon_{i}
\end{gathered}
$$

where $r_{i, t}$ denotes the stock index return for country $i$ on day $t,{ }^{5} D^{\text {fall }}$ is a dummy variable indicating fall, ${ }^{6} S A D$ is the SAD measure and equals $\left[D_{i, t}^{\text {fall-wint } e r} \times l e n_{i, t}\right]$ where $D^{\text {fall-winter }}$ is a fall-winter dummy ${ }^{7}$ and len is the normalized number of hours of night, which depends on the latitude $\delta$ of a country's stock exchange, ${ }^{8} D^{\text {Monday }}$ is a dummy variable indicating Mondays, $D^{\operatorname{tax}}$ is a dummy variable equal to one on the first five trading days and the last trading day of a country's fiscal year. Cloud, Precip and Temp are measures of percentage cloud cover on a given day, the amount of precipitation, and the temperature, respectively.

Table 2, Panel A replicates the regression in equation (1) using the data provided by Lisa Kramer. The results are identical to those presented in KKL2003 (except for New Zealand, where our fall and SAD coefficients are smaller by $6 \%$ and $9 \%$, respectively). KKL2003 denotes statistical significance based on one-sided tests since KKL2003's

\footnotetext{
${ }^{5}$ Following KKL2003, we first run each regression without lagged returns. If a Ljung-Box (1978) $\chi^{2}$ test rejects the hypothesis of no residual autocorrelation for up to six lags at the one percent significance level, we include another lag of returns and repeat the procedure, including up to two lags of returns. Extending this procedure up to ten lags of returns only slightly weakens the statistical significance of the coefficient on the SAD interaction term.

${ }^{6}$ The fall dummy is equal to one between September 21 and December 20 for countries in the Northern Hemisphere, equal to one between March 21 and June 20 in the southern hemisphere, and zero otherwise.

${ }^{7}$ The fall-winter dummy equals one between September 21 and March 20 for countries in the northern hemisphere, and equals one between March 21 and September 20 in the southern hemisphere.

${ }^{8}$ Calculation of normalized hours of night, len $_{t}$, at latitude $\delta$ follows KKL2003: First, the sun's declination angle is $\lambda_{t}=0.4102 \times\left[\left(\frac{2 \pi}{365}\right)\left(j_{t}-80.25\right)\right]$. Let $\phi_{t}=7.72 \times \arccos \left[-\tan \left(\frac{2 \pi \delta}{360}\right) \tan \left(\lambda_{t}\right)\right]$, then $\operatorname{len}_{t}=12-\phi_{\mathrm{t}}$ for the northern hemisphere and $\operatorname{len}_{t}=\phi_{\mathrm{t}}-12$ for the southern hemisphere. $j_{\mathrm{t}}$ represents the number of the day in the year, ranging from 1 to 365 (366 in a leap year).
} 
hypotheses are directional. We follow convention by being more agnostic about the hypotheses and report significance based on two-sided tests.

In order to extend the sample from 9 countries (12 indices) to 36 countries (47 indices) and to extend the time period through 2008, we collect daily stock return data as well as daily temperature, daily cloud cover, and daily precipitation for each market as described in Section 3. We have to make judgment calls regarding the environmental variables and the treatment of holidays. KKL2003 uses daily temperature and precipitation variables for the period from January 1994 through December 1999 (and from May 1997 through December 1999 in Germany). Cloud cover, temperature and precipitation are monthly averages for the remaining sample. We were able to collect daily weather data from the National Oceanic and Atmospheric Administration (NOAA) for a much longer time series, which covers the vast majority of the sample for which we have return data. For consistency, we limit our sample to a time period where we can obtain daily weather variables. While the original dataset used in KKL2003 does not contain any daily cloud cover, 15,748 out of the 101,314 observations (about 15.5\%) do contain daily temperature and precipitation data. Our extended sample for 36 countries and data through 2008 contains a total of 349,860 observations for which we were able to collect daily temperature, precipitation, and cloud cover observations.

In addition, we adjust for non-trading days in a slightly different way. Datastream often reports zero returns for non-trading days. KKL2003 uses Datastream's vacation files and various other sources to remove holidays. This approach misses a few holidays and also days on which the exchange closed for other reasons. We therefore classify any day as a non-trading day if fewer than $10 \%$ of individual stocks exhibit a price change. 
For periods where we lack data on individual stocks we follow KKL2003's robustness check and exclude all zero return days. In order to understand how these different decisions affect the results we replicate the findings for the original 12 indices in the original time frame, in steps.

In Table 2, Panel B we replicate the regression of KKL2003 using the return and daily weather data we collected. The original KKL2003 sample contains some observations for which daily weather variables are not available. Limiting our sample to a time period where we can obtain daily weather variables reduces the sample size of the original dataset used in KKL2003 to 82,371 observations (to about 81.3\%). We find that the coefficients on the fall dummy become insignificant in Canada and for the S\&P 500 index, and the coefficients on the SAD interaction term become insignificant in the U.K. and Germany, and marginally insignificant in Sweden. Is this loss of significance due to the reduction in sample size or due to the use of daily weather controls (or both)? To answer this question we restrict the data provided by Lisa Kramer to the 82,371 observations for which we collected daily weather data from NOAA. As the results displayed in Table 2, Panel $\mathrm{C}$ indicate, restricting the sample to the time frame with daily NOAA data yields results that are very similar to Panel B In other words, the differences in statistical significance between Panels A and B are largely due to the change in sample size. Performing a sub-period analysis is obviously important and we will do this in Section 6.4.

Table 3 extends these tests to the full sample and shows that the fall coefficient is negative and significant in 15 of 36 countries (19 of 47 indices) while the SAD coefficient is positive and significant in seven countries (11 indices) and both are 
significant in five countries (9 indices). Either the fall or the SAD interaction term is statistically significant in about half the markets that we examine.

\section{Auxiliary implications of the SAD model}

The SAD hypothesis posits that the seasonality in international stock returns depicted in Figure 1 is the result of seasonal variation in mood. While the modelpredicted returns of KKL2003 correspond only loosely to aggregate patterns in seasonal depression, they do fit the empirically observed returns quite well. This poses a problem. On the one hand, we cannot evaluate the validity of the SAD model, which was developed to explain seasonal stock returns, by simply examining the fit between modelpredicted returns and actual stock returns. On the other hand, we do not want to dismiss the model out of hand just because the model is based on incorrect assumptions. As Box and Draper point out, "all models are wrong, but some are useful” (Box and Draper, 1987, p74). One possibility of evaluating the usefulness of the SAD model is to identify auxiliary implications and test whether they are borne out by the data. In this section we do just that.

As mentioned before, the SAD hypothesis states that seasonal patterns in clinical depression among SAD-afflicted investors cause seasonal variation in aggregate stock returns. KKL2003 tests this hypothesis with a model that uses a fall dummy to proxy for the onset of SAD depression and a SAD measure, which is a fall-winter dummy, interacted with a country's normalized length of night, "to capture the effects of SAD on markets” (p. 333). This SAD measure varies through time to capture seasonality in depression and by latitude to account for the "more pronounced stock market effects due 
to SAD in countries at more extreme latitudes where the fall and winter months have relatively shorter days” (p. 333). Previous studies have shown that a country's latitude is correlated with the fraction of its population that is affected by SAD. To illustrate, on January $3^{\text {rd }}$ of each year the SAD measure takes on a value of 7.9 for Iceland, 2.8 for the United States, and of 1.2 for Hong Kong.

Is there evidence of a more pronounced stock market effect in countries at higher latitudes? Since Table 3 lists countries in descending order of latitude, it is quite easy to inspect whether the SAD measure and the fall dummy are statistically significant more often for countries at higher latitudes. But KKL2003 also suggests that the economic magnitude of the SAD effect is more pronounced in extreme-latitude countries like Iceland and less pronounced in lower latitude countries like Hong Kong. This relation is difficult to glean from Table 3 because the SAD measure varies by country and modelpredicted stock returns are obtained by summing up the regression intercept, the product of the fall dummy and its coefficient, and the product of the SAD measure and its coefficient. Figure 2 illustrates this by plotting model-predicted returns for three selected countries calibrated to the regressions in Table 3. We exclude weather, tax, and weekend effects to focus on the impact of SAD. The figure shows that a low latitude country, like Hong Kong at 22 degrees north, has quite extreme returns predicted by the onset and relief of SAD depression. While a higher latitude country like the U.S. at 51 degrees north has a much less pronounced SAD effect. This is somewhat surprising since the psychological studies listed in Appendix A do not indicate that SAD or subsyndromal SAD are more pronounced in China than in the United States. 
The difficulty in assessing the economic magnitude of the SAD effect across countries may explain why KKL2003 emphasizes the time-series aspect of the model and does not formally investigate the cross-sectional predictions. Examining the country-bycountry variation in the economic magnitude of the purported SAD effect may provide additional insights.

KKL2003 expects "more pronounced stock market effects due to SAD in countries at more extreme latitudes” (p. 333) because a country’s latitude is correlated with the fraction of its population that is affected by SAD. To examine this correlation we turn to the psychological literature and gather data on the prevalence of SAD across countries. Appendix A lists the fraction of each country's population found to be affected by SAD and by a milder version called "subsyndromal SAD” as well as the underlying academic source. Overall, we are able to obtain this prevalence data for half the countries in our sample. Table 4 shows correlations between the coefficients on the SAD measure and the fall dummy, three different measures of the prevalence of SAD in the general population, latitude, and the coefficient on a SAD onset/recovery variable (to be discussed in section 6.3). The correlations between latitude and the various measures of the prevalence of SAD within the general population are statistically significant and economically large. While latitude proxies for the prevalence of SAD across countries, this correlation is less than perfect. To more directly investigate the cross-sectional implications of the SAD hypothesis we examine whether the coefficients on the fall dummy are more negative and the coefficients on the SAD interaction term are more positive in countries where SAD is more prevalent. 
As Table 4 shows, the Spearman rank correlation of the SAD measure is negative for both latitude and prevalence. The Pearson correlations are 0.05 with latitude and negative 0.31 with prevalence. While these results appear to be at odds with the predicted relation between the SAD coefficient and prevalence, they are hard to interpret because the country-by-country variation of the SAD measure may not quite capture the countryby-country variation in the magnitude of the SAD effect. As a result, the negative correlations might merely reflect that the SAD model overstates SAD in northern latitudes or understates at low latitudes. In contrast, interpreting the coefficient on the fall dummy is straightforward since it measures the drop in country-level stock returns during fall without any reference to the country's latitude. The SAD hypothesis predicts a more pronounced drop in aggregate stock markets in countries where the marginal trader is more likely to be afflicted by SAD and therefore implies a negative correlation between a country's prevalence of SAD and its corresponding fall coefficient. But this prediction is not borne out by the data: the fall coefficients are essentially uncorrelated with the various measures of the prevalence of SAD in the general population.

To summarize, a previously untested implication of the SAD model is that the seasonal patterns in stock index returns are more pronounced in countries where SAD is more prevalent. Our results show that neither latitude nor prevalence of SAD in the general population is significantly related to either the coefficient on the SAD measure or the coefficient on the fall dummy. Despite all this, Table 3 shows that either the fall coefficients are significantly negative or the SAD coefficients are significantly positive for almost half of the countries in our sample. How does this square with the results documented so far? We turn to this question in the next section. 


\section{Econometric reexamination of the SAD effect}

\subsection{Mechanical relation between fall dummy and SAD interaction term}

In this subsection we show that the SAD interaction term does not differ materially from a fall-winter dummy and that the SAD effect is mechanically driven by a de facto overlapping dummy variable specification and higher returns around the turn of the year. As noted in the introduction, the significance on the fall dummy (the overlapped dummy) could be driven entirely by higher returns in winter, the time period when the two dummies do not overlap. Recall that the SAD interaction term is constructed as a fall-winter dummy, that is, a dummy equal to one during fall and winter, interacted with normalized length of night. Normalized length of night is a slowly moving, highly persistent level variable and multiplying the fall-winter dummy by it should, therefore, not alter the inferences from the model, although it impacts the magnitude of the coefficients. Figure 3 illustrates this intuition by plotting the return predicted by the SAD model (excluding the Monday, Tax and weather effects) and the return predicted by a model that drops the normalized length-of-night interaction and includes the fall-winter dummy. These model predicted returns are calibrated to Hong Kong Total Market returns and superimposed on the actual average daily Hong Kong Total Market returns. Focusing on the fall-winter dummy specification, the dashed line shows that model-predicted returns during fall are not different from spring and summer, but returns are higher around the turn of the year. A simple way to test whether the overlap of the SAD and fall variables drives the significant results on the fall dummy is to split the SAD variable into fall SAD and winter SAD and run the following regression: 


$$
\begin{aligned}
& r_{i, t}=\alpha_{i}+\rho_{1, i} r_{i, t-1}+\rho_{2, i} r_{i, t-2}+\beta_{i, \text { fall }} D_{i, t}^{\text {fall }}+\beta_{i, \text { fallsAD }} \text { fallSAD }+\beta_{i, \text { winSAD }} \text { winSAD } \\
& +\beta_{i, \text { Monday }} D_{i, t}^{\text {Monday }}+\beta_{i, \text { tax }} D_{i, t}^{\text {tax }}+\beta_{i, \text { Cloud }} \text { Cloud }_{i}+\beta_{i, \text { Precip }} \text { Precip }_{i}+\beta_{i, \text { Temp }} \text { Temp }_{i}+\varepsilon_{i}
\end{aligned},
$$

where fallSAD is a fall dummy interacted with normalized length of night, and winSAD is a winter dummy interacted with normalized length of night. If the original model (Equation 1) is correctly specified, decomposing the SAD interaction term into fallSAD and winSAD should not affect the results. In contrast, if the significance of the fall dummy is mechanically induced, splitting the SAD variable should eliminate the significance of the fall dummy. Table 5 shows that the fall dummy is negative and insignificant in all but one market (Greece), and the SAD interaction term is positive and significant only in winter (except for Canada). ${ }^{9}$ The winSAD coefficient is positive and significant in eight markets (12 indices) and negative and significant in one (Indonesia). It appears that the SAD effect is driven entirely by returns during winter and that the negative fall dummy coefficient is due to the de facto overlapping-dummy specification.

\subsection{SAD effect around the turn of the year}

An extensive literature documents unusual behavior of stock returns at the turn of the calendar year, which occurs at the beginning of winter in northern hemisphere countries. Small firms tend to outperform large firms in the month of January, and winner firms seem to appreciate during December. While these return patterns are predominantly attributed to tax-induced trading, additional explanations include window-dressing by

\footnotetext{
${ }^{9}$ In unreported tests, we drop the fallSAD measure to avoid multicolinearity with the fall dummy. We find similar results. Fall is significant in Greece and for equally weighted AMEX returns. winSAD is positive and significant in six markets (10 indices) and negative and significant in one (Indonesia).
} 
institutions, information, and bid-ask bounce. ${ }^{10}$ KKL2003 controls for the higher returns around the turn of the year by including a tax dummy equal to one on the last and the first five trading days of a country's fiscal year. To examine the months in which the SAD effect is concentrated, we allow the SAD coefficient to vary on a monthly basis, effectively relaxing KKL2003's constraint that returns are equally sensitive to SAD in each month during fall and winter.

To conform to the seasonal quarters specified by the SAD model, we do not use calendar months but instead divide the fall and winter period between the two equinoces into six subperiods: the first period is from September 21 to October 20, the second period is from October 21 to November 20, and so forth until the sixth period, which starts on February 21 and ends on March $20 .{ }^{11}$ These subperiods allow us to examine whether the coefficient on the SAD interaction is particularly pronounced during the period from December 21 through January 20. We specify the following regression model:

$$
\begin{aligned}
r_{i, t}= & \alpha_{i}+\rho_{1, i} r_{i, t-1}+\rho_{2, i} r_{i, t-2}+\beta_{i, \text { fall }} D_{i, t}^{\text {fall }}+\beta_{i, \text { Mon }} D_{i, t}^{\text {Monday }}+\beta_{i, \text { tax }} D_{i, t}^{\text {tax }} \\
& +\sum_{p=1}^{6} \beta_{p, i, \text { SAD }} D_{p}^{\text {Period }} S A D+\beta_{i, \text { Cloud }} \operatorname{Cloud}_{i}+\beta_{i, \text { Precip }} \text { Precip }_{i}+\beta_{i, \text { Temp }} \text { Temp }_{i}+\varepsilon_{i}
\end{aligned}
$$

The dummy variable $D_{p}^{\text {period }}$ is equal to one for the p-th period. Since the SAD interaction term effectively acts like a dummy variable (as demonstrated in the previous section), the SAD coefficients in Equation (3) test whether stock index returns during the six periods are significantly different from average stock returns during spring and summer (after controlling for tax effects, Mondays, fall and weather).

\footnotetext{
${ }^{10}$ See Moller and Zilca (2008) and Sun and Tong (2009) for recent research on the January effect and Chen and Singal (2004) for a literature review.

${ }^{11}$ For the six countries in the southern hemisphere the first period is from March 21 to April 20, and so forth.
} 
As Table 6 shows, all SAD coefficients are insignificant during the three months of fall, except positive and significant coefficients for the second and third periods in South Africa (April to June) ${ }^{12}$. It appears that the SAD interaction term picks up higher returns around the turn of the year while the de facto overlapping dummy specification mechanically induces a negative and significant coefficient on the fall dummy.

\subsection{KKL2007 onset variable}

Partly in response to draft versions of this article, a recent paper proposes a modified econometric specification of the SAD hypothesis (Kamstra et al., 2007). This specification includes a single "onset/recovery” measure that is constructed in several steps: first, based on studies that document onset of SAD symptoms and recovery from SAD symptoms (Young et al., 1997; Lam, 1998), the paper constructs a monthly SAD "incidence" variable. This incidence variable is the difference between the cumulative proportion of subjects who have experienced onset of SAD symptoms and the cumulative proportion of subjects who have fully recovered from SAD. Second, the paper interpolates this monthly SAD incidence variable to daily observations by using a spline function. Third, it runs a logistic regression of the interpolated daily incidence on an instrument (the length of day in hours in New York), where the non-linear functional form is chosen to ensure that the fitted values range from zero to 100 percent. These fitted values constitute the SAD onset/recovery measure.

\footnotetext{
${ }^{12}$ In unreported results, we exclude the fall dummy to avoid the multicollinearity between the SAD measure and the fall dummy discussed earlier and we find similar results. SAD during fall is negative and significant for 2 of 141 possible coefficients, positive and significant in 1, and insignificantly different from zero for the remaining 138 coefficients. In contrast, 12 of the 47 northern hemisphere indices have positive and significant SAD coefficients during the turn of the year (period 4 from December 21 through January 20). The number of positive and significant coefficients reduces to two for the period ending in February and two in the period ending in March.
} 
This SAD-onset/recovery measure improves upon the previously discussed specification along two dimensions. First, it acknowledges that the typical SAD sufferer experiences relief from symptoms in April (Lam, 1998) and not as soon as the days lengthen (Section 2). Second, it eliminates the de facto overlapping dummy specification discussed in Section 6.1 by creating a new continuous seasonal variable that peaks in fall at the onset of SAD, and dips in March and April when SAD typically goes into remission. Figure 4 superimposes the fall dummy and the SAD variable calibrated to equally weighted NYSE returns (dashed line) with the SAD-onset/recovery measure (thin line) and the KKL2003 SAD model (thick line). The figure shows several differences between these two measures: both specifications predict the lowest returns in September, but the thin line of the SAD-onset/recovery measure is continuous and symmetric, with values close to zero at both the summer and the winter solstice, and predicts the highest returns in March, while the thick line of the KKL2003 SAD specification is discontinuous and asymmetric around the winter solstice, with values set to zero during spring and summer, and predicts highest returns at the winter solstice.

In Table 7 we replace the SAD interaction term and the fall dummy with the SAD-onset/recovery measure:

$$
\begin{gathered}
r_{i, t}=\alpha_{i}+\rho_{1, i} r_{i, t-1}+\rho_{2, i} r_{i, t-2}+\beta_{i, \text { Onset Recovery }} \text { OnsetRecovery }_{i, t}+\beta_{i, \text { Monay }} D_{i, t}^{\text {Monday }}+ \\
\beta_{i, \text { tax }} D_{i, t}^{\text {tax }}+\beta_{i, \text { Cloud }} \text { Cloud }_{i}+\beta_{i, \text { Precip }} \text { Precip }_{i}+\beta_{i, \text { Temp }} \text { Temp }_{i}+\varepsilon_{i}
\end{gathered}
$$

As described above, the SAD-onset/recovery measure is based on clinical onset and recovery patterns among North Americans and calibrated to the length of night in New York City. While we run country-by-country regressions, we do not calibrate the SADonset/recovery measure to reflect either geographical differences in SAD onset/recovery 
or the length of night. The former is not possible because we are unable to obtain clinical studies of onset/recovery for a sufficient number of countries, and the latter is not a problem because the coefficient on the onset/recovery measure will reflect cross-country variations. In fact, using the same measure across all countries in our sample allows us to examine whether the magnitude of the coefficients differs as predicted by the SAD hypothesis.

The SAD hypothesis as specified by KKL2003 predicts a positive coefficient on the SAD-interaction term and a negative coefficient on the fall dummy. For the coefficient on the onset/recovery measure the same hypothesis predicts a negative coefficient. Table 7 shows that the onset/recovery measure is negative and statistically significant in six out of 36 countries. As Table 4 shows, the magnitude of the SADonset/recovery coefficients is weakly correlated with latitude in the predicted direction. Countries at higher latitudes have somewhat more negative coefficients. The Pearson correlation is negative 0.16 and the Spearman rank correlation is negative 0.25 , although both correlations are statistically insignificant. In contrast, the magnitude of the SADonset/recovery coefficients is weakly correlated with the fraction of each country's population found to be affected by SAD but opposite to the predicted direction. Countries where SAD is more prevalent among the general population have somewhat more positive coefficients: the Pearson correlation is 0.17 and the Spearman rank correlation is 0.32, although both correlations are statistically insignificant.

In summary, the onset/recovery measure better tracks when the typical SAD sufferer experiences relief from symptoms and eliminates the de facto overlapping dummy specification of KKL2003. But the statistical significance of this measure across 
countries is weak and there is no evidence that the effect of SAD onset and recovery on stock index returns is more pronounced in countries where a greater fraction of the population suffers from SAD.

\subsection{Robustness}

We have performed a large number of additional tests to ensure that our findings are robust. In Table 2 we find that restricting our sample to observations where daily weather variables are available results in the loss of statistical significance of the SAD-interaction term and the fall dummy in several countries. This raises the possibility that the statistical significance is time-period specific. To investigate this question we rerun the regression model specified in Equation (1) year-by-year. To ensure that our regressions have sufficient power, we require a minimum of 125 daily observations each year. Table 8 reports that across all countries and years, the coefficient on the fall dummy is negative and significant in eight percent of country-year observations (and negative but insignificant in an additional 52 percent), while the coefficient on the SAD measure is positive and significant in eight percent of observations (and positive and insignificant in an additional 54 percent). The fact that the coefficients on both the SAD measure and fall dummy are frequently of the wrong sign is consistent with our assertion that the SAD hypothesis does not help explain seasonality in international stock returns.

We have also examined monthly returns to see if the sheer number of daily observations drives the statistical significance of the SAD model in Table 3. It doesn't. The monthly specification suffers from the same overlapping dummy problem as the daily data do. We have also examined additional controls for known seasonalities in stock 
returns, including the Halloween effect of Bouman and Jacobsen (2002) and longer controls for January returns. Inclusion of these variables does weaken the significance of the SAD and fall coefficients even further - but this is not surprising given that the SAD measure acts like a dummy and including more dummy variables creates an even more extreme overlapping dummy problem. We also examine the performance of the model without the fall dummy to see if this alters the performance of the SAD measure, though this ignores KKL2003's belief that the onset of depression in fall drives down returns. The SAD-interaction term is statistically insignificant for all 47 stock market indices after we drop the fall dummy from the specification. Not surprisingly, given the return patterns we see in Figure 1, dropping the fall dummy reduces both the magnitude and the significance of the SAD coefficients. We have also examined the magnitude of the SAD effect across industries. Similar to Jacobsen and Visaltanachoti (2006), we have found a fair amount of variation across industries within countries, which would be surprising if the SAD-afflicted investors owned well diversified portfolios and they rebalanced their portfolio proportionately in response to changes in depression. These robustness checks are omitted for brevity but available from the authors upon request.

\section{Conclusion}

The SAD hypothesis states that seasonal patterns in clinical depression among SAD-afflicted investors cause seasonal variation in their risk aversion, which in turn causes seasonality in aggregate stock returns. This paper shows that the SAD hypothesis is unsupported by the psychological literature, that prevalence of SAD in the general population is not related to stock returns, and that the econometric specification of the 
SAD model mechanically induces the statistical significance cited as evidence for the SAD effect.

While our econometric critique is specific to the proposed SAD effect, our review of the medical and psychological evidence has broader implications for behavioral studies in finance and economics. Our critical reexamination illustrates that an association between sentiment-affecting events and stock prices is not sufficient to credibly establish a causal link between the two. Many articles that study whether investor sentiment impacts stock returns focus on carefully identifying suitable events that have been shown to affect mood and are unlikely to affect the economic opportunities of individuals or corporations. Yet these studies tend to skip three important steps by not examining whether the event-induced mood change actually affects investor perception of financial risk or return, whether such a change in perception manifests itself in trading behavior, and whether these sentiment-based trades impact stock prices. It is essential to carefully scrutinize these links for one to conclude that sentiment affects security prices. 


\section{References}

Barber, B.M., Odean, T., 2000. Trading is hazardous to your wealth: The common stock investment performance of individual investors. Journal of Finance 55, 773-806.

Barber, B.M., Odean T., 2001. Boys will be boys: Gender, overconfidence, and common stock investment. Quarterly Journal of Economics 116, 261-292.

Barber, B.M., Odean, T., 2002. Online investors: Do the slow die first? Review of Financial Studies 15, 455-489.

Booker, J.M., Hellekson, C.J., 1992. Prevalence of seasonal affective disorder in Alaska. American Journal of Psychiatry 149, 1176-1182.

Bouman, S., Jacobsen, B., 2002. The Halloween indicator, sell in May and go away: Another puzzle. American Economic Review 92, 1618-1635.

Box, G.E.P., Draper, N.R., 1987. Empirical Model-Building and Response Surfaces. John Wiley and Sons, Inc.: New York.

Broman, J.E., Hetta, J., 1998. Prevalence of seasonal affective disorders and related symptoms at two latitudes in Sweden. Society for Light Treatment and Biological Rhythms Abstracts 10, 228.

Carton, S., Jouvent, R., Bungener, C., Wildlöcher, D., 1992. Sensation seeking and depressive mood. Personality and Individual Differences 13, 843-849.

Carton, S., Morand, P., Bungenera, C., Jouvent, R., 1995. Sensation-seeking and emotional disturbances in depression: Relationship and evolution. Journal of Affective Disorders 34, 219-225.

Chang, S., Chen, S., Chou, R., Lin, Y., 2008. Weather and intraday patterns in stock returns and trading activity. Journal of Banking and Finance 32, 1754-1766.

Chen, H., Singal, V., 2004. All things considered, taxes drive the January effect. Journal of Financial Research 27, 351-372.

Clark, L., Iversen, S.D., Goodwin, G.M., 2001. The influence of positive and negative mood states on risk taking, verbal fluency, and salivary cortisol. Journal of Affective Disorders 63, 179-187.

Dam, H., Jakobsen, K., Mellerup, E., 1998. Prevalence of winter depression in Denmark. Acta Psychiatrica Scandinavica 97, 1-4. 
Eagles, J.M., Gavin, M., Andrew, J., Boshier, F.J., 1996. Seasonal affective disorder among psychiatric nurses in Aberdeen. Journal of Affective Disorders 37, 129135.

Edmans, A., García, D., Norli, Ø., 2007. Sports sentiment and stock returns. Journal of Finance 64, 1967-1998.

Eisenberg, A., Baron, J., Seligman, M., 1998. Individual differences in risk aversion and anxiety. Working paper, University of Pennsylvania.

Elbi, H., 2002. Seasonal affective disorder in eight groups in Turkey: A cross-national perspective. Journal of Affective Disorders 70, 77-84.

Goetzmann, W.N., Zhu, N., 2005. Rain or shine: Where is the weather effect? European Financial Management 5, 559-578.

Grinblatt, M., Keloharju, M., 2000. The investment behavior and performance of various investor types: A study of Finland's unique data set. Journal of Financial Economics 55, 43-67.

Grinblatt, M., Keloharju, M., 2001a. How distance, language, and culture influence stockholdings and trades. Journal of Finance 56, 1053-1073.

Grinblatt, M., Keloharju, M., 2001b. What makes investors trade? Journal of Finance 56, 589-616.

Grinblatt, M., Keloharju, M., 2008. Sensation seeking, overconfidence, and trading activity. Journal of Finance 64, 549-578.

Gultekin, M.N., Gultekin, N.B., 1983. Stock market seasonality: International evidence. Journal of Financial Economics 12, 469-481.

Hagfors, C., Thorell, L., Arned, M., 1995. Seasonality in Finland and Sweden, an epidemiologic study, preliminary results. Society for Light Treatment and Biological Rhythms Abstracts 7, 22.

Haggarty, J.M., Cernovsky, Z., Husni, M., Minor, P., Kermeen P., Merskey, H., 2002. Seasonal affective disorder in an Arctic community. Acta Psychiatrica Scandinavica 105, 378-84.

Hamermesh, D.S., 2007. Viewpoint: Replication in economics. Canadian Journal of Economics 40, 715-733. 
Han, L., Wang, K., Cheng, Y., Du, Z., Rosenthal, N., Primeau, F., 2000. Summer and winter patterns of seasonality in Chinese college students: A replication. Comprehensive Psychiatry 41, 57-62.

Han, L., Wang, K., Du, Z., Chen, Y., Simons, J., Rosenthal, N., 2000. Seasonal variation in mood and behavior among Chinese medical students. American Journal of Psychiatry 157, 133-135.

Hedge, A.L., Woodson, H., 1996. Prevalence of seasonal changes in mood and behavior during the winter months in central Texas. Psychiatry Research 62, 265-271.

Hirshleifer, D., Shumway, T., 2003. Good day sunshine: Stock returns and the weather. Journal of Finance 58, 1009-1032.

Hockey, G.R.J., Maule, A.J., Clough, P.J., Bdzola, L., 2000. Effects of negative mood states on risk in everyday decision making. Cognition and Emotion 14, 823-855.

Horvath, P., Zuckerman, M., 1993. Sensation seeking, risk appraisal and risky behavior. Personality and Individual Differences 14, 41-51.

Ito, A., Ichihara, M., Hisanaga, N., Ono, Y., Kayukawa, Y., Ohta, T., et al. 1992. Prevalence of seasonal mood changes in low latitude area: Seasonal pattern assessment questionnaire score of Quezon city workers. Japanese Journal of Psychiatry and Neurology 46, 249.

Jacobsen, B., Mamun, A., Visaltanachoti, N., 2006. Seasonal, size and value anomalies. Working paper, Erasmus University Rotterdam.

Jacobsen, B., Marquering, W., 2008. Is it the weather? A comment on studies linking weather and stock market behaviour. Journal of Banking and Finance 32, 526540.

Jacobsen, B., Marquering, W., 2009. Is it the weather? Response. Journal of Banking and Finance 33, 583-587.

Joshi, N.K., Bhattarai, R.C., 2007. Stock returns and economically neutral behavioural variables relationship in the Nepalese stock market. Economic Review Occasional Paper 19, 43-58.

Kahneman, D., Tversky, A., 1979. Prospect theory: An analysis of decision under risk. Econometrica 47, 263-292. 
Kamstra, M.J., Kramer, L.A., Levi, M.D., 2003. Winter blues: A SAD stock market cycle. American Economic Review 93, 324-343.

Kamstra, M.J., Kramer, L.A., Levi, M.D.,2007. Opposing seasonalities in treasury versus equity returns. Working paper, University of Toronto.

Kasof, J., 2009. Cultural variation in seasonal depression: Cross-national differences in winter versus summer patterns of seasonal affective disorder. Journal of Affective Disorders 115, 79-86.

Kasper S., Rogers, S.L., Yancey, A., Schulz, P.M., Skwerer, R.G., Rosenthal, N.E., 1989. Phototherapy in individuals with and without subsyndromal seasonal affective disorder. Archives of General Psychiatry 46, 837-844.

Konradsen, H., 1995. Årstidsavhengig affektiv forstyrrelse: En emperisk undersøkelse av forekomst blant 6300 unge voksne fra 58 til 703N. Working paper, University of Tromsø.

Lam, R.W., 1998. Seasonal affective disorder: Diagnosis and management. Primary Care Psychiatry 4, 63-74.

Lee, H., Sung, S., Han, C., Kim, Y., Kim, S., Lee, M., et al., 2005. G-protein \$3 subunit C825T polymorphism tends to be associated with seasonal variation in young male college students. Neuropsychobiology 52, 135-139.

Lee, H., Sung, S., Lim, S., Paik, J., Kim, L., 2006. Seasonality associated with the serotonin 2A receptor -1438 A/G polymorphism. Journal of Affective Disorders 95, 145148.

Levine, M.E., 1995. Seasonal symptoms in the sub-Arctic. Military Medicine 160, 110114.

Ljung, G., Box, G., 1978. On a Measure of lack of fit in time series models. Biometrika 65, 297-303.

Lo, A.W., Repin, D.V., Steenbarger, B.N., 2005. Fear and greed in financial market: A clinical study of day-traders. American Economic Review 95, 352-360.

MacKinnon, J.,White, H., 1985. Some heteroskedasticity-consistent covariance matrix estimators with improved finite sample properties. Journal of Econometrics 29, 305-325. 
Magnusson, A., 2000. An overview of epidemiological studies on seasonal affective disorder. Acta Psychiatrica Scandinavica 101, 176-184.

Magnusson A., Stefansson J.G., 1993a. Prevalence of seasonal affective disorder in Iceland. Archives of General Psychiatry 50, 941-946.

Magnusson A., Axelsson J., 1993b. The prevalence of seasonal affective disorder is low among descendants of Icelandic emigrants in Canada. Archives of General Psychiatry 50, 947-951.

Mersch, P., 2001. Prevalence from population surveys. In: Patonen, T., Magnusson, A. (Eds.), Seasonal Affective Disorder: Practice and Research. Oxford University Press: Oxford.

Mersch, P., Middendorp, H., Bouhuys, A., Beersma, D., van den Hoofdakker, R., 1995. The prevalence of seasonal affective disorder in the Netherlands. Acta Neuropsychiatrica 7, 47-49.

Moller, N., Zilca, S., 2008. The evolution of the January effect. Journal of Banking and Finance 32, 447-457.

Morse, W., 1998. Risk taking in personal investments. Journal of Business and Psychology 13, 281-288.

Morrissey, S.A., Raggatt, P.T., James, B., Rogers, J., 1996. Seasonal affective disorder: Some epidemiological findings from a tropical climate. Australian and New Zealand Journal of Psychiatry 30, 579-586.

Muscettola, G., Barbato, G., Ficca, G., Beatrice, M., Puca, M., Aguglia, E., Amati, A., 1995. Seasonality of mood in Italy: Role of latitude and sociocultural factors. Journal of Affective Disorders 33, 135-139.

Odean, T., 1998a. Volume, volatility, price, and profit when all traders are above average. Journal of Finance, 53, 1887-934.

Odena, T., 1998b. Are investors reluctant to realize their losses? Journal of Finance 53, 1775-1798.

Odean, T., 1999. Do Investors Trade Too Much? American Economic Review 89, 12791298. 
Ozaki, N., Ono, Y., Ito, A., Rosenthal, N., 1995. Prevalence of seasonal difficulties in mood and behavior among Japanese civil servants. American Journal of Psychiatry 152, 1225-1227.

Palinkas, L., Houseal, M., Rosenthal, N., 1996. Subsyndromal seasonal affective disorder in Antarctica. Journal of Nervous and Mental Disease 184, 530-34.

Palinkas, L., Houseal, M., 2000. Stages of change in mood and behavior during a winter in Antarctica. Environment and Behavior 32, 128-141.

Partonen, T., Lönnqvist, J., 1998. Seasonal affective disorder. Lancet 352, 1369-74.

Popper, R., 1934. Logik Der Forschung. Springer: Vienna. First published in English in 1959 as The Logic of Scientific Discovery. Basic Books: New York.

Raghunathan, R., Pham, M.T., 1999. All negative moods are not equal: Motivational influences of anxiety and sadness on decision making. Organizational Behavior and Human Decision Processes 79, 56-77.

Rastad, C., Sjoden, P., Ulfberg, J., 2005. High prevalence of self-reported winter depression in a Swedish county. Psychiatry and Clinical Neurosciences 59, 666675.

Rosen, L.N., Targum, S.D., Terman, M., Bryant, M.J., Hoffman, H., Kasper, S.F., Hamovit, J.R., Docherty, J.P., Welch, B., Rosenthal, N.E., 1990. Prevalence of seasonal affective disorder at four latitudes. Psychiatry Research 31, 131-144.

Rozeff, M., Kinney, W., 1976. Capital market seasonality: The case of stock returns. Journal of Financial Economics. 3, 379-402.

Schlager, D., Schwartz, J., Bromet, E., 1993. Seasonal variations of current symptoms in a healthy population. British Journal of Psychiatry 163, 322-326.

Smoski, M., Lynch, T., Rosenthal, Z., Cheavens, J., Chapman, A., Krishnan, R., 2008. Decision-making and risk aversion among depressive adults. Journal of Behavior Therapy and Experimental Psychiatry 39, 567-576.

Soriano J., Ciupagea, C., Rohan, K., Neculai, D., Yousufi, S., Guzman, A., Postolache, T., 2007. Seasonal variations in mood and behavior in Romanian postgraduate students. The Scientific World Journal 7, 870-879. 
Srisurapanont, M., Intaprasert, S., 1999. Seasonal variations in mood and behaviour: Epidemiological findings in the north tropics. Journal of Affective Disorders 54, 97-99.

Sun, Q., Tong, W., 2009. Risk and the January effect. Journal of Banking and Finance, forthcoming.

Terman, M., Botticelli, S., Link, B., Link, M., Quitkin, F., Hardon, T., Rosenthal, N., 1989. Seasonal symptom patterns in New York: Patients and population. In: Thompson, C., Silverstone, T. (Eds.), Seasonal Affective Disorder. CNS (Clinical Neuroscience) Publishers: London.

Thompson, C., 1989. The syndrome of seasonal affective disorder. In: Thompson, C., Silverstone, T. (Eds.), Seasonal Affective Disorder. CNS (Clinical Neuroscience) Publishers: London.

Wirz-Justice, A., Graw, P., Kräuchi, K., Pöldinger, W., 1989. Phototherapy in Switzerland: 'Mehr Licht'. In: Thompson, C., Silverstone, T. (Eds.), Seasonal Affective Disorder. CNS (Clinical Neuroscience) Publishers: London.

Wirz-Justice, A., Kräuchi, K., Graw, P., Schulman, J., Wirz, H., 1992. Seasonality in Switzerland: An epidemiological survey. Society for Light Treatment and Biological Rhythms Abstracts 4, 33.

Wong, A., Carducci, B., 1991. Sensation seeking and financial risk taking in everyday money matters. Journal of Business and Psychology 5, 525-530.

Wu, J., Zhang, L., 2009. Do anomalies exist ex ante? Working paper, University of Michigan.

Young, M., Meaden, P., Fogg, L., Cherin, E., Eastman, C., 1997. Which environmental variables are related to the onset of seasonal affective disorder? Journal of Abnormal Psychology 106, 554-562.

Zuckerman, M., 1979. Sensation Seeking: Beyond the optimal Level of Arousal. Lawrence Erlbaum Associates: Hillsdale, NJ.

Zuckerman, M., 1984. Sensation seeking: A comparative approach to a human trait. Behavioral and Brain Sciences 7, 413-471.

Zuckerman, M., 1994. Behavioral Expression and Biosocial Bases of Sensation Seeking. Cambridge University Press: Cambridge. 


\section{Appendix A}

Prevalence of Seasonal Affective Disorder in General Population Studies

\begin{tabular}{|c|c|c|c|}
\hline Location & $\begin{array}{l}\text { Prevalence SAD in the } \\
\text { General Population (\%) }\end{array}$ & $\begin{array}{c}\text { Prevalence of Sub- } \\
\text { Syndromal SAD in the } \\
\text { General Population (\%) }\end{array}$ & Source \\
\hline Australia - Northern & 1.70 & 1.40 & Morrisey et al. (1996) \\
\hline Canada - Baffin Island & 6.30 & 12.60 & Haggarty et al (2002) \\
\hline Canada - Manitoba & 1.20 & 3.30 & Magnusson et al. (1993b) \\
\hline China & 2.40 & 5.70 & Han, et al. (2000a) \\
\hline China & 5.60 & 6.30 & Han, et al. (2000b) \\
\hline Denmark & 12.40 & 4.80 & Dam et al. (1998) \\
\hline Finland & 7.10 & 11.80 & Hagfors et al. (1995) \\
\hline Finland & 3.40 & 12.60 & Hagfors et al. (1995) \\
\hline Iceland & 2.80 & 7.50 & Magnusson et al. (1993a) \\
\hline Italy & 4.40 & 4.80 & Muscelotta et al. (1995) \\
\hline Japan - Nagoya & 0.86 & 0.86 & Ozaki et al. (1995) \\
\hline Netherlands & 3.00 & 8.20 & Mersch et al. (1995) \\
\hline Norway - Men & 6.50 & 10.10 & Konradsen (1995) \\
\hline Norway - Women & 12.80 & 10.80 & Konradsen (1995) \\
\hline Philippines & 0.00 & 0.00 & Ito et al. (1992) \\
\hline Romania & 3.78 & 7.35 & Soriano et al. (2007) \\
\hline South Korea & 11.60 & 5.90 & Lee, et al. (2005) \\
\hline South Korea & 11.40 & 5.80 & Lee, et al. (2006) \\
\hline Sweden & 3.90 & 13.90 & Hagfors et al. (1995) \\
\hline Sweden & 3.50 & 22.50 & Broman et al. (1998) \\
\hline Sweden & 8.00 & 10.80 & Rastad, et al (2005) \\
\hline Switzerland & 2.20 & 8.90 & Wirz-Justice et al. (1992) \\
\hline Thailand & 1.03 & $\mathrm{n} / \mathrm{a}$ & Srisurapanont and Intaprasert (1999) \\
\hline Turkey & 4.86 & 8.35 & Elbi, et al. (2002) \\
\hline UK - Aberdeeen & 2.90 & 9.50 & Eagles et al. (1996) \\
\hline USA - Alaska & 9.20 & 19.10 & Booker et al (1992) \\
\hline USA - Alaska - Men & 5.80 & 18.80 & Levine (1995) \\
\hline USA - Alaska - Women & 12.90 & 18.80 & Levine (1995) \\
\hline USA - Florida & 1.40 & 2.60 & Rosen et al. (1990) \\
\hline USA - Maryland & 4.30 & 13.50 & Kasper et al. (1989) \\
\hline USA - Maryland & 6.30 & 10.40 & Rosen et al. (1990) \\
\hline USA - New Hampshire & 9.70 & 11.00 & Rosen et al. (1990) \\
\hline USA - New York & 4.70 & 12.50 & Rosen et al. (1990) \\
\hline USA - Texas & 3.70 & 17.80 & Hedge et al. (1996) \\
\hline
\end{tabular}

The table lists the percentage of individuals with SAD and a milder condition called subsyndromal SAD. Data are from general population studies and the table lists the article from which the data come. Many of the articles referenced below where found through two meta studies by Magnusson (2000) and Kasof (2009). 
Patrick J. Kelly, Felix Meschke, Sentiment and stock returns: The SAD anomaly revisited, Journal of Banking \& Finance, June 2010, Volume 34.6:1308-1326. Publisher's official version: http://dx.doi.org/10.1016/j.jbankfin.2009.11.027. Open Access version: http://kuscholarworks.ku.edu/dspace/.

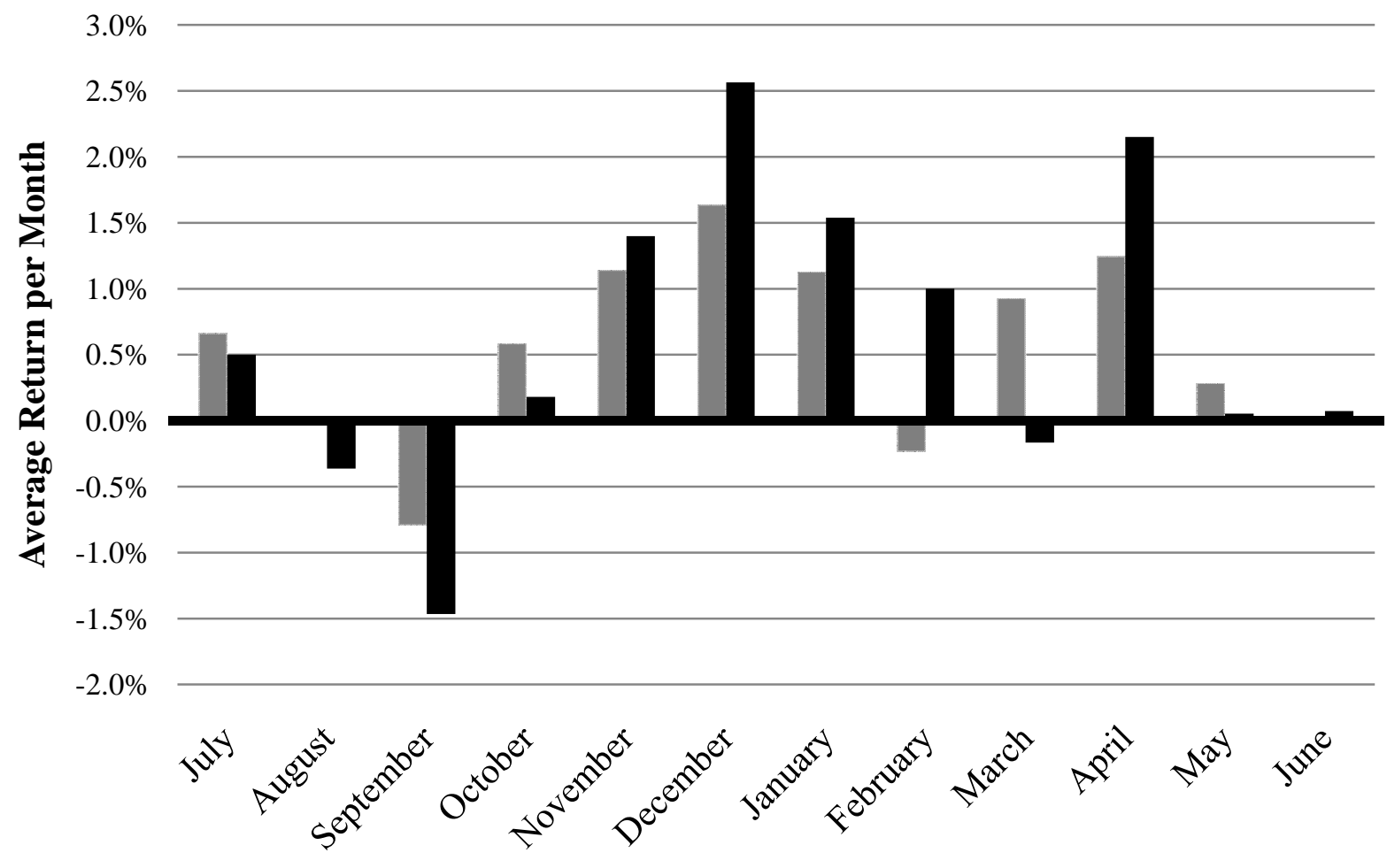

- S\&P500 1948-2008

- Equally Weighted 35 Market Return exUS 1993-2008

Fig. 1. Average monthly return around the world. The Figure above plots the equally weighted average monthly index return for all countries included in this study. For each country we select one index and calculate continuously compounded monthly returns from daily data (for the US we select the S\&P500, for the U.K., the Datastream Total Market Index). Then we calculate the simple monthly average return across all 35 indices, excluding the U.S., in the given month. We only calculate average returns if all series are available. For this reason the series covers 1993 through 2008. Then we average across all years and the average is presented above. The U.S. series is the average over 1948 through 2008. 


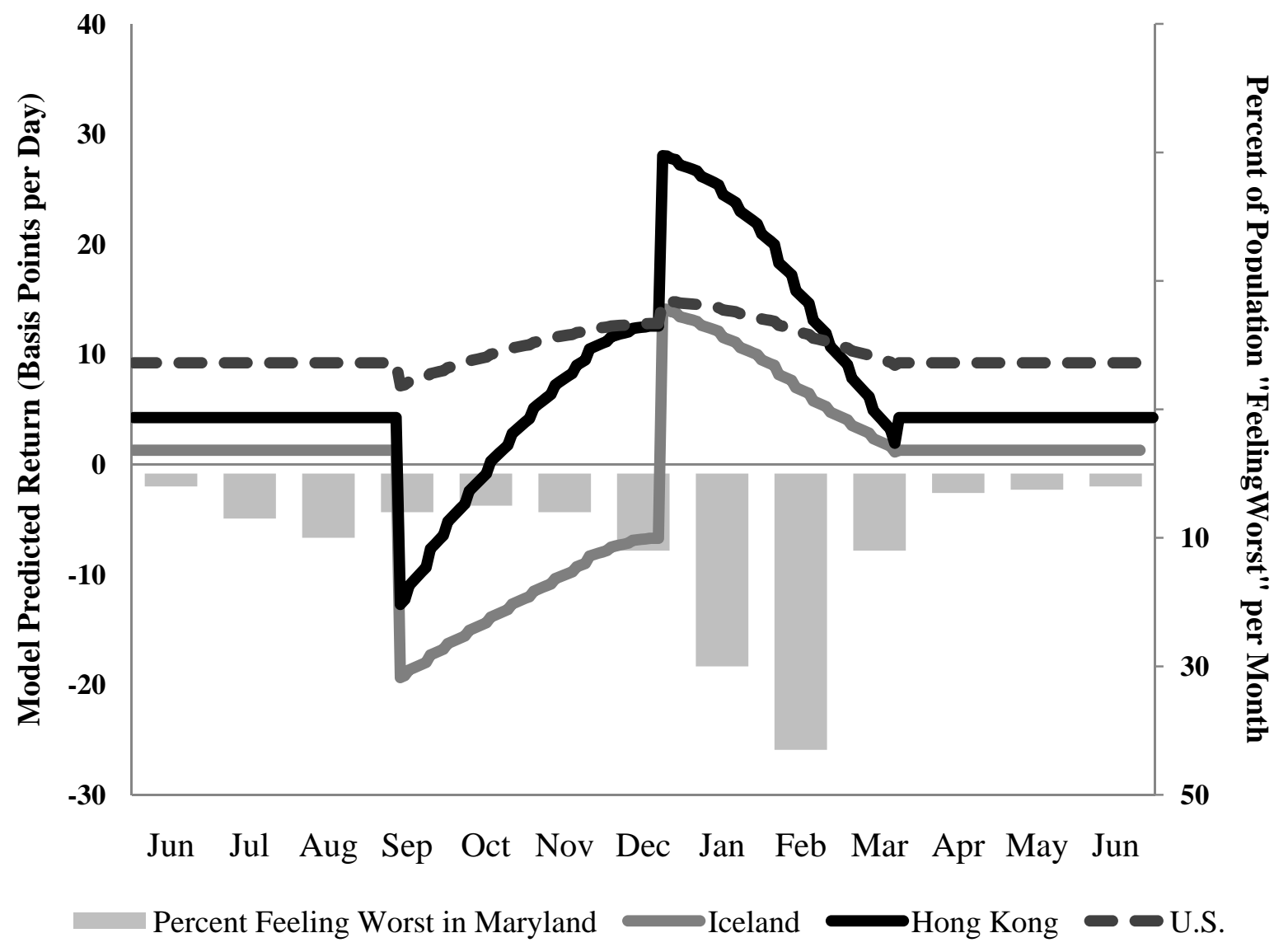

Fig. 2. Model predicted returns and timing of peak depression. The figure above plots seasonal variations in stock returns as predicted by KKL2003's SAD model for three selected countries and seasonal variations in the fraction of people feeling worst. Specifically, the exact model expected returns in basis points plotted are: Iceland $1.3+20.8 \times$ $D^{\text {fall }}+1.5 \times S A D$, Hong Kong $4.3+15.5 \times D^{\text {fall }}+19.2 \times S A D$, U.S. (S\&P 500) $9.2+2.1 \times D^{\text {fall }}+1.9 \times S A D$.

The left axis corresponds to these three time series. On the right axis the figure recreates a chart from Kasper et al. (1989) which presents the percentage of the population reporting feeling worst in that month in a study of randomly selected households in Montgomery County, Maryland, USA. The right axis ordering is reversed, e.g. 43.2\% of respondents report feeling worst in January and/or February, whereas $9.6 \%$ of respondents report feeling worst in July and/or August. 
Patrick J. Kelly, Felix Meschke, Sentiment and stock returns: The SAD anomaly revisited, Journal of Banking \& Finance, June 2010, Volume 34.6:1308-1326.

Publisher's official version: http://dx.doi.org/10.1016/j.jbankfin.2009.11.027. Open Access version: http://kuscholarworks.ku.edu/dspace/.

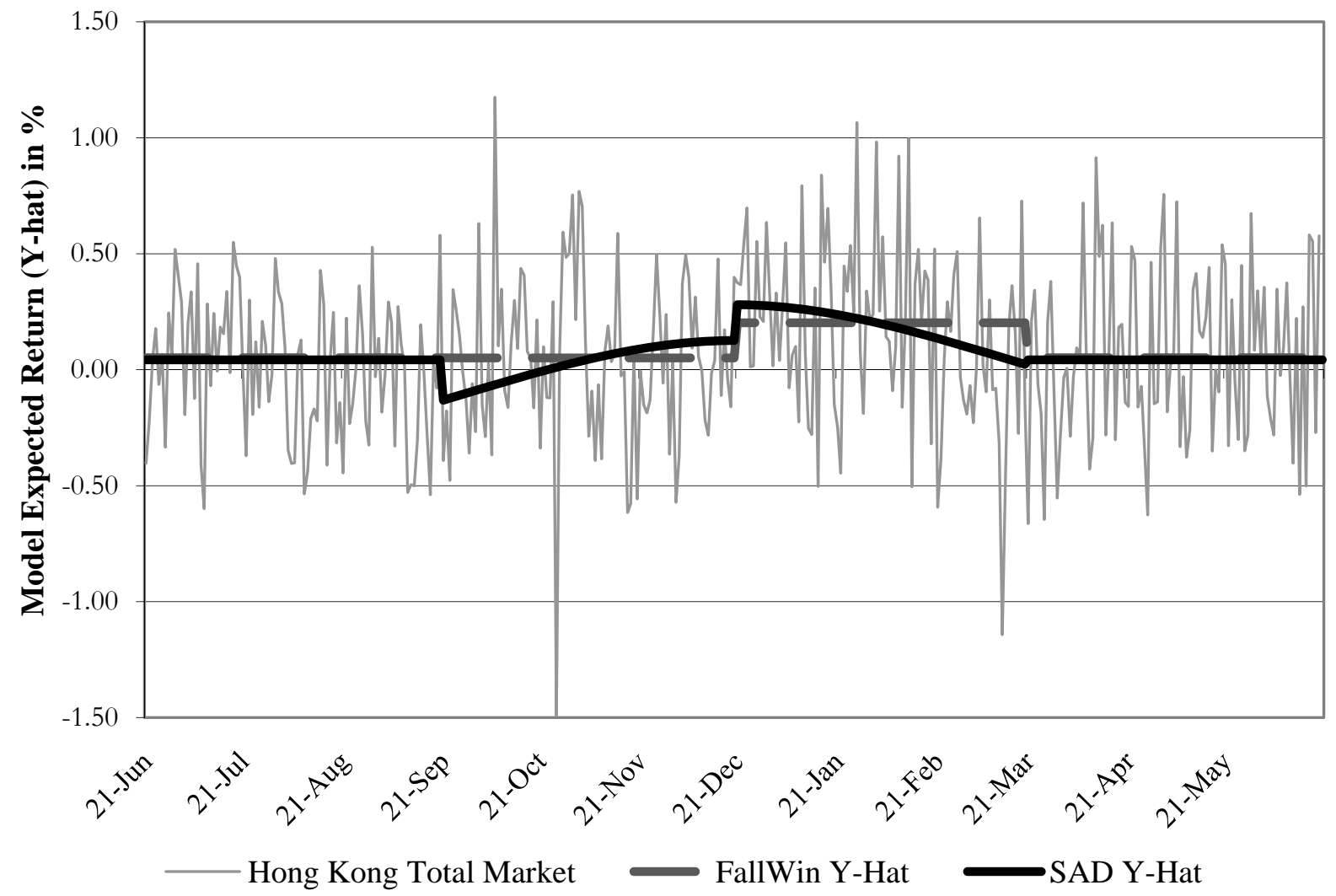

Fig. 3. Model predicted returns for the Hong Kong Total Market index. This graph presents model expected returns for the SAD model (in black) and fall-winter-dummy model (dashed line in grey/red) excluding the Monday, tax and weather variables. Coefficients for the SAD model come from Equation 1 and Table 3. Fall-winter-dummy model runs the following regression:

$r_{i, t}=\alpha_{i}+\rho_{1, i} r_{i, t-1}+\rho_{2, i} r_{i, t-2}+\beta_{i, \text { fall }} D_{i, t}^{\text {fall }}+\beta_{i, \text { fall-winter }} D_{i, t}^{\text {fall-winter }}+{ }_{i, \text { Monday }} D_{i, t}^{\text {Monday }}+\beta_{i, \text { tax }} D_{i, t}^{\text {tax }}+\varepsilon_{i}$

where $D_{i, t}^{\text {fall-winter }}$ is a dummy that is 1 from Sept. 21 through Mar. 20th and 0 other wise. The volatile grey line is average daily Datastream Total Market returns for Hong Kong over the sample period. 
Patrick J. Kelly, Felix Meschke, Sentiment and stock returns: The SAD anomaly revisited, Journal of Banking \& Finance, June 2010, Volume 34.6:1308-1326.

Publisher's official version: http://dx.doi.org/10.1016/j.jbankfin.2009.11.027. Open Access version: http://kuscholarworks.ku.edu/dspace/.

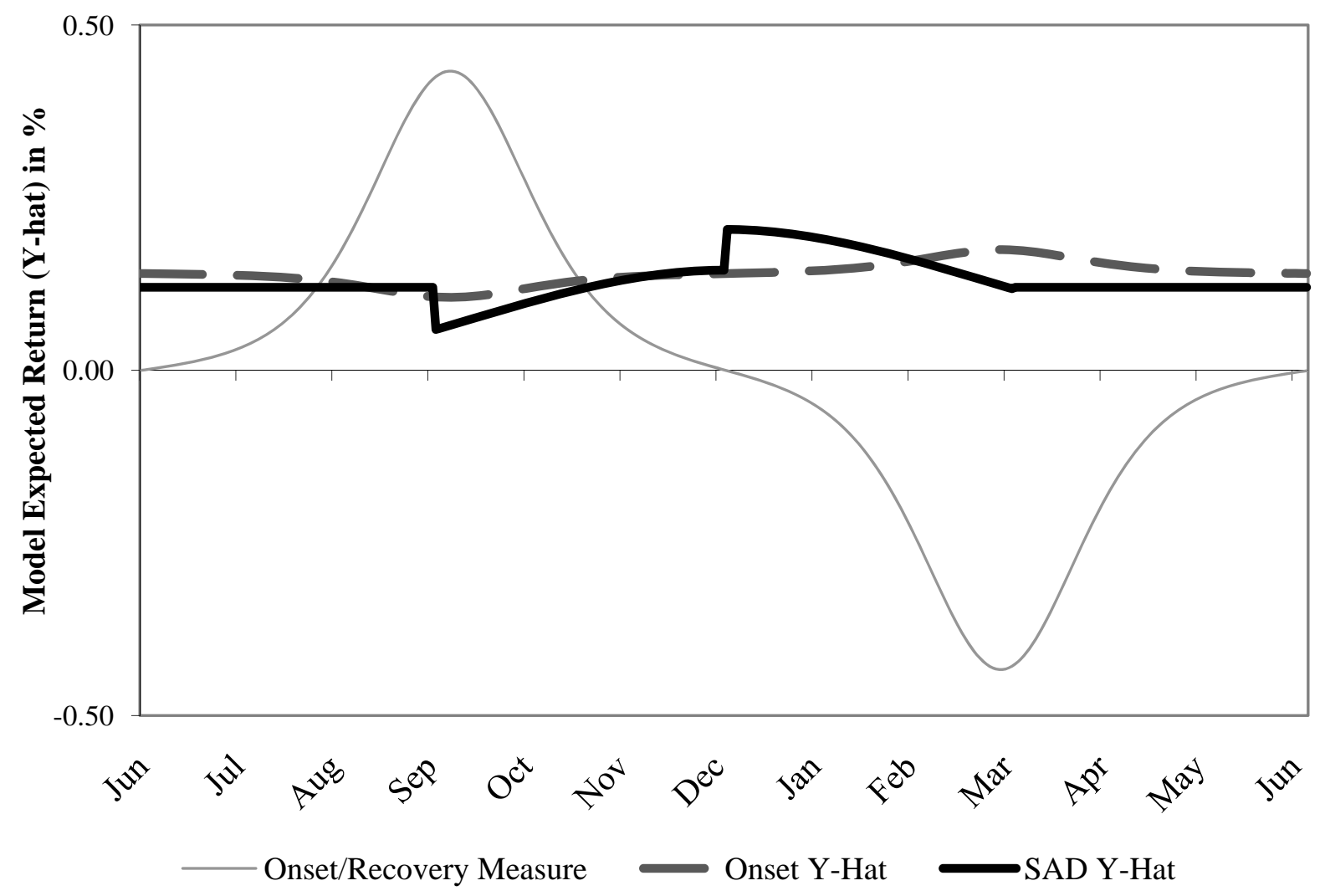

Fig. 4. The onset/recovery measure and model predicted returns for equally weighted NYSE returns. This graph presents model expected returns for the SAD model (in black) and the Onset/Recovery model (dashed line in grey/red) excluding the Monday, Tax and Weather variables. Coefficients for the SAD and Onset/Recovery models come from Equations 1 and 4 respectively. The thin light-grey line is the raw Onset/Recover measure itself. 
Table 1

Summary statistics for the return indices. Indices are from Datastream International except the NYSE, AMEX, NASDAQ and S\&P500 returns which are from CRSP. First Returns and First Weather are the first year of data availability. All series have returns through 2008, except Veckans Affärer (2003), Capital 40 (2004), and the AMEX, NASDAQ, and NYSE series (2007). Taiwan Weighted is missing precipitation data past 2001. Weather Days is the percentage of daily observations for which none of the weather variables is missing. Tax Yr. Start denotes the first day of the tax calendar.

\begin{tabular}{|c|c|c|c|c|c|c|}
\hline Country & Series Name & Latitude & $\begin{array}{c}\text { First } \\
\text { Returns }\end{array}$ & $\begin{array}{c}\text { First } \\
\text { Weather }\end{array}$ & $\begin{array}{c}\text { Weather } \\
\text { Days (\%) }\end{array}$ & $\begin{array}{c}\text { Tax Yr. } \\
\text { Start }\end{array}$ \\
\hline \multicolumn{7}{|c|}{ Panel A: Countries Examined in KKL (2003) } \\
\hline Sweden & Veckans Affärer & $59 N$ & 1982 & 1982 & 84.5 & $1 / 1$ \\
\hline United Kingdom & FTSE 100 & $51 \mathrm{~N}$ & 1984 & 1984 & 99.7 & $4 / 6$ \\
\hline Germany & DAX 30 Performance & $50 \mathrm{~N}$ & 1965 & 1971 & 70.5 & $1 / 1$ \\
\hline Canada & TSE 300 & $43 N$ & 1969 & 1973 & 86.5 & $1 / 1$ \\
\hline United States & S\&P 500 & $41 \mathrm{~N}$ & 1928 & 1948 & 98.1 & $1 / 1$ \\
\hline United States & Value Weighted AMEX ex-Div & $41 \mathrm{~N}$ & 1962 & 1962 & 97.5 & $1 / 1$ \\
\hline United States & Value Weighted NASDQ ex-Div & $41 N$ & 1972 & 1972 & 96.8 & $1 / 1$ \\
\hline United States & Value Weighted NYSE ex-Div & $41 N$ & 1926 & 1948 & 98.1 & $1 / 1$ \\
\hline Japan & Nikkei 225 & $36 \mathrm{~N}$ & 1950 & 1953 & 71.7 & $4 / 1$ \\
\hline South Africa & Total Market & $26 S$ & 1973 & 1973 & 81.0 & $3 / 1$ \\
\hline Australia & All Ordinaries & $34 S$ & 1980 & 1980 & 97.7 & $7 / 1$ \\
\hline New Zealand & Capital 40 & $37 \mathrm{~S}$ & 1990 & 1996 & 98.7 & $4 / 1$ \\
\hline \multicolumn{7}{|c|}{ Panel B: Extended Sample } \\
\hline Finland & HEX General Index & $64 N$ & 1987 & 1987 & 90.1 & $1 / 1$ \\
\hline Iceland & OMX Iceland All Share & $64 N$ & 1993 & 1993 & 94.8 & $1 / 1$ \\
\hline Norway & Total Market & $62 \mathrm{~N}$ & 1980 & 1980 & 99.4 & $1 / 1$ \\
\hline Sweden & OMX Affärsvärldens Generalinde & $59 N$ & 1980 & 1980 & 74.9 & $1 / 1$ \\
\hline Denmark & Copenhagen KFX & $56 \mathrm{~N}$ & 1989 & 1989 & 97.3 & $1 / 1$ \\
\hline Ireland & Total Market & $53 \mathrm{~N}$ & 1973 & 1973 & 96.9 & $4 / 6$ \\
\hline Netherlands & AEX Index & $52 \mathrm{~N}$ & 1973 & 1973 & 99.0 & $1 / 1$ \\
\hline United Kingdom & Total Market & $51 \mathrm{~N}$ & 1969 & 1973 & 98.8 & $4 / 6$ \\
\hline Belgium & Banque Bruxelles Lambert 30 & $50 \mathrm{~N}$ & 1970 & 1973 & 98.5 & $1 / 1$ \\
\hline Austria & ATX 50 (DS Calculated) & $47 \mathrm{~N}$ & 1973 & 1973 & 95.4 & $1 / 1$ \\
\hline Switzerland & Total Market & $47 \mathrm{~N}$ & 1973 & 1973 & 94.5 & $1 / 1$ \\
\hline France & Total Market & $46 \mathrm{~N}$ & 1973 & 1973 & 99.5 & $1 / 1$ \\
\hline Italy & Total Market & $42 \mathrm{~N}$ & 1973 & 1973 & 99.2 & $1 / 1$ \\
\hline United States & Dow Jones Industrial Average & $41 \mathrm{~N}$ & 1928 & 1948 & 98.8 & $1 / 1$ \\
\hline United States & Equal Weighted AMEX ex-Div & $41 \mathrm{~N}$ & 1962 & 1962 & 97.5 & $1 / 1$ \\
\hline United States & Equal Weighted NASDQ ex-Div & $41 N$ & 1972 & 1972 & 96.8 & $1 / 1$ \\
\hline United States & Equal Weighted NYSE ex-Div & $41 \mathrm{~N}$ & 1926 & 1948 & 98.1 & $1 / 1$ \\
\hline China & Total Market & $40 \mathrm{~N}$ & 1991 & 1991 & 84.0 & $1 / 1$ \\
\hline Spain & Madrid SE General & $40 N$ & 1974 & 1974 & 99.6 & $1 / 1$ \\
\hline Greece & Total Market & $39 N$ & 1988 & 1988 & 96.5 & $1 / 1$ \\
\hline Turkey & Total Market & $39 N$ & 1988 & 1988 & 99.3 & $1 / 1$ \\
\hline Korea & Korea South Composite (KOSPI) & $37 \mathrm{~N}$ & 1975 & 1975 & 92.0 & $1 / 1$ \\
\hline Jordan & Amman SE Financial Market & $31 N$ & 1988 & 1988 & 79.8 & $1 / 1$ \\
\hline Mexico & FTSE Mexico Index & $23 \mathrm{~N}$ & 1987 & 1987 & 82.9 & $1 / 1$ \\
\hline Taiwan & Taiwan Weighted & $23 \mathrm{~N}$ & 1971 & 1973 & 85.3 & $1 / 1$ \\
\hline Hong Kong & Total Market & $22 \mathrm{~N}$ & 1973 & 1973 & 83.1 & $4 / 1$ \\
\hline India & National Index (100) & $20 \mathrm{~N}$ & 1989 & 1989 & 86.9 & $4 / 1$ \\
\hline Thailand & S.E.T Index & $15 \mathrm{~N}$ & 1975 & 1975 & 89.4 & $1 / 1$ \\
\hline Philippines & PSE Composite Index & $13 \mathrm{~N}$ & 1986 & 1986 & 81.1 & $1 / 1$ \\
\hline Sri Lanka & All Share & $7 \mathrm{~N}$ & 1985 & 1985 & 39.8 & $4 / 1$ \\
\hline Malaysia & Composite & $2 \mathrm{~N}$ & 1980 & 1980 & 93.5 & $1 / 1$ \\
\hline Singapore & Total Market & $1 \mathrm{~N}$ & 1973 & 1973 & 91.3 & $1 / 1$ \\
\hline Indonesia & Jakarta Composite Index & $5 S$ & 1983 & 1983 & 89.4 & $1 / 1$ \\
\hline Australia & Total Market & $34 S$ & 1973 & 1973 & 95.7 & $7 / 1$ \\
\hline New Zealand & FSTE New Zealand Index & $37 \mathrm{~S}$ & 1987 & 1996 & 99.1 & $4 / 1$ \\
\hline
\end{tabular}


Table 2

Daily return regression on the fall dummy, SAD measure, and weather controls using the KKL2003 sample. Table 2 reports coefficients and (t-statistics) from a regression of daily index returns in percent on a fall dummy equal to one from Sept. 21 through Dec. 20 and the SAD interaction term, constructed as described in the text, plus control variables. Control variables include: a tax dummy equal to one the day before the end of the tax year and the first five days of the tax year, a Monday dummy, temperature in Celsius, cloud cover in percent of sky overcast, and precipitation in millimeters. In panels B and C weather variables are gathered from hourly weather data from NOAA and averaged over 6am to 4pm (Temperature, Cloud Cover, and Precipitation). Control variables coefficients are multiplied by 100 to conserve space. In this table only, the sample is restricted to include no more data than used by KKL2003. In Panels A and C the data are the data used in KKL2003, graciously provided by Lisa Kramer. In Panel B the data are those collected by the authors. Return data are from Datastream and CRSP. Weather variables come from the National Atmospheric and Oceanic Administration's National Climate Data Center Global Hourly Surface data and are 6am to 4pm averages. The last column reports the unadjusted R-squared on top and the p-value from a Ljung-Box (1978) chi-square test for autocorrelation up to six lags in parentheses. Lagged index returns are included to control for autocorrelation. Following KKL2003 lags of returns are added up to two until a Ljung-Box (1978) chi-squared test suggests there is no residual autocorrelation to six lags at the 1-percent level. In Panel A we use the same number of lags as reported in KKL2003. The intercept and coefficients of lagged returns are not reported to conserve space. t-statistics control for heteroskedasticity following MacKinnon and White (1985).

\begin{tabular}{|c|c|c|c|c|c|c|c|c|}
\hline Country & Fall & SAD & Tax & Monday & Temp & Cloud & Precip. & RSQ \\
\hline \multicolumn{9}{|c|}{ Panel A: Countries and Time Period Examined in KKL (2003) using data provided by Lisa Kramer } \\
\hline Sweden & $-0.113^{*}$ & $0.028 *$ & -3.6 & 13.5 & 0.1 & -0.1 & -37.4 & 0.017 \\
\hline Veckans Affärer & $(-2.01)$ & $(1.97)$ & $(-0.76)$ & $(0.84)$ & $(0.09)$ & $(-0.17)$ & $(-1.28)$ & $(0.01)$ \\
\hline \multirow[t]{2}{*}{ U.K. FTSE 100} & -0.036 & $0.030 *$ & $-11.7 * *$ & 14.6 & -1.7 & -0.1 & -27.1 & 0.009 \\
\hline & $(-0.80)$ & $(2.03)$ & $(-2.98)$ & $(1.55)$ & $(-1.51)$ & $(-0.30)$ & $(-1.03)$ & $(0.00)$ \\
\hline \multirow[t]{2}{*}{ Germany } & -0.070 & 0.025 & $-14.9 * *$ & 16.5 & 0.1 & 0.1 & -13.0 & 0.008 \\
\hline & $(-1.90)$ & (1.58) & $(-4.85)$ & (1.67) & $(0.10)$ & $(0.36)$ & $(-0.53)$ & $(0.00)$ \\
\hline \multirow[t]{2}{*}{ Canada } & $-0.069 *$ & $0.052 * *$ & $-13.1 * *$ & 3.4 & -0.3 & 0.2 & 16.8 & 0.030 \\
\hline & $(-2.12)$ & $(3.24)$ & $(-5.48)$ & $(0.43)$ & $(-0.88)$ & $(1.16)$ & $(0.63)$ & $(0.50)$ \\
\hline \multirow[t]{2}{*}{ U.S. - S\&P500 } & $-0.058 *$ & $0.038 *$ & $-20.9 * *$ & 6.3 & -0.2 & 0.3 & 11.5 & 0.011 \\
\hline & $(-2.23)$ & $(2.43)$ & $(-9.47)$ & $(1.10)$ & $(-0.58)$ & $(1.80)$ & $(0.74)$ & $(0.00)$ \\
\hline \multirow[t]{2}{*}{ U.S. - } & $-0.084 * *$ & $0.035 *$ & $-28.0 * *$ & $18.3^{* *}$ & -0.2 & 0.1 & 2.1 & 0.091 \\
\hline & $(-3.15)$ & $(2.34)$ & $(-12.44)$ & $(2.71)$ & $(-0.84)$ & $(0.54)$ & $(0.13)$ & $(0.00)$ \\
\hline \multirow[t]{2}{*}{ U.S. - vwNASD } & $-0.134 * *$ & $0.071^{* *}$ & $-25.6 * *$ & 6.7 & -0.3 & 0.3 & 8.7 & 0.033 \\
\hline & $(-3.26)$ & $(2.96)$ & $(-7.48)$ & $(0.72)$ & $(-0.61)$ & $(1.35)$ & $(0.40)$ & $(0.24)$ \\
\hline \multirow[t]{2}{*}{ U.S. - vwNYSE } & -0.040 & 0.026 & $-12.4 * *$ & 1.0 & -0.1 & 0.0 & 4.6 & 0.027 \\
\hline & $(-1.37)$ & (1.61) & $(-5.18)$ & $(0.14)$ & $(-0.21)$ & $(0.26)$ & $(0.27)$ & $(0.00)$ \\
\hline \multirow[t]{2}{*}{ Japan } & -0.060 & 0.037 & -4.0 & 0.9 & -0.4 & -0.1 & 9.5 & 0.002 \\
\hline & $(-1.91)$ & (1.55) & $(-1.42)$ & $(0.12)$ & $(-1.11)$ & $(-0.46)$ & $(0.58)$ & $(0.00)$ \\
\hline \multirow[t]{2}{*}{ South Africa } & -0.033 & 0.113 & $-12.3 * *$ & 1.2 & -0.1 & 1.5 & 13.7 & 0.010 \\
\hline & $(-0.89)$ & (1.62) & $(-3.01)$ & $(0.11)$ & $(-0.26)$ & $(1.56)$ & $(0.61)$ & $(0.08)$ \\
\hline Australia & 0.007 & 0.029 & -3.8 & 12.5 & $-0.5 *$ & 0.5 & -32.8 & 0.010 \\
\hline All Ordinaries & $(0.22)$ & $(0.89)$ & $(-1.12)$ & $(1.60)$ & $(-2.17)$ & $(0.80)$ & $(-1.02)$ & $(0.00)$ \\
\hline New Zealand & $-0.102 *$ & 0.043 & $-20.3 * *$ & 21.4 & 0.1 & 1.1 & 46.2 & 0.009 \\
\hline Capital 40 & $(-2.05)$ & (1.59) & $(-3.82)$ & $(1.48)$ & $(0.45)$ & (1.49) & $(0.59)$ & $(0.75)$ \\
\hline
\end{tabular}


Patrick J. Kelly, Felix Meschke, Sentiment and stock returns: The SAD anomaly revisited, Journal of Banking \& Finance, June 2010, Volume 34.6:1308-1326. Publisher's official version: http://dx.doi.org/10.1016/j.jbankfin.2009.11.027. Open Access version: http://kuscholarworks.ku.edu/dspace/.

\begin{tabular}{|c|c|c|c|c|c|c|c|c|}
\hline Country & Fall & SAD & Tax & Monday & Temp & Cloud & Precip. & RSQ \\
\hline \multicolumn{9}{|c|}{ Panel B: Countries and Time Period in KKL (2003) using data collected by authors with daily NOAA weather } \\
\hline Sweden & $-0.123^{*}$ & 0.025 & 18.8 & -9.5 & -0.2 & $-1.9 *$ & -0.3 & 0.031 \\
\hline Veckans Affärer & $(-2.05)$ & $(1.93)$ & $(1.20)$ & $(-1.85)$ & $(-0.78)$ & $(-2.23)$ & $(-0.41)$ & $(0.09)$ \\
\hline \multirow[t]{2}{*}{ U.K. FTSE 100} & -0.033 & 0.021 & 14.3 & $-10.7^{* *}$ & -0.3 & -1.3 & 0.0 & 0.011 \\
\hline & $(-0.72)$ & $(1.50)$ & (1.49) & $(-2.65)$ & $(-1.03)$ & $(-1.75)$ & $(-0.07)$ & $(0.43)$ \\
\hline \multirow[t]{2}{*}{ Germany } & $-0.088^{*}$ & 0.020 & 17.1 & $-13.4 * *$ & -0.2 & -1.1 & 0.2 & 0.011 \\
\hline & $(-2.00)$ & $(1.30)$ & (1.47) & $(-3.47)$ & $(-0.86)$ & $(-1.71)$ & $(0.40)$ & $(0.06)$ \\
\hline \multirow[t]{2}{*}{ Canada } & -0.061 & $0.042 *$ & 0.3 & -10 . & 0.1 & -0.6 & -0.1 & 0.029 \\
\hline & $(-1.66)$ & $(2.56)$ & $(0.03)$ & $(-3.3$ & $(0.66)$ & $(-1.08)$ & $(-1.68)$ & $(0.03)$ \\
\hline \multirow[t]{2}{*}{ U.S. - S\&P500 } & -0.032 & $0.025 *$ & -2.3 & $-16.0 * *$ & 0.0 & $-0.8 * *$ & $-0.4^{*}$ & 0.020 \\
\hline & $(-1.42)$ & $(2.27)$ & $(-0.39)$ & $(-7.47)$ & $(0.23)$ & $(-2.88)$ & $(-2.41)$ & $(0.00)$ \\
\hline \multirow[t]{2}{*}{ U.S. - } & $-0.085 * *$ & $0.039 * *$ & $18.1^{*}$ & & 0.0 & 8* & 02 & 0.098 \\
\hline & $(-3.35)$ & (3.03) & (2.43) & & $(-0.15)$ & & $(-1.30)$ & $(0.00)$ \\
\hline \multirow[t]{2}{*}{ U.S. - vwNASD } & $-0.138 * *$ & $0.067 * *$ & 2.5 & & 0.2 & -1 & -0.5 & 0.033 \\
\hline & $(-3.59)$ & (3.35) & $(0.26)$ & & (1.05) & & $(-1$. & $(0.26)$ \\
\hline \multirow[t]{2}{*}{ U.S. - vwNYSE } & -0.046 & $0.028 *$ & -0.6 & -12 & 0.0 & & $-0.5^{*}$ & 0.030 \\
\hline & $(-1.74)$ & $(2.18)$ & $(-0.08)$ & $(-5.21)$ & $(0.19)$ & & $(-2.15)$ & $(0.70)$ \\
\hline \multirow[t]{2}{*}{ Japan } & -0.038 & 0.009 & -3.2 & -6.9 & -0.2 & $-1.4^{*}$ & 0.0 & 0.006 \\
\hline & $(-0.92)$ & $(0.32)$ & $(-0.33)$ & $(-1.89)$ & $(-0.75)$ & $(-2.50)$ & $(0.35)$ & $(0.02)$ \\
\hline \multirow[t]{2}{*}{ South Africa } & -0.045 & 0.093 & -0.9 & $-13.4 * *$ & $1.3^{*}$ & 0.9 & -0.1 & 0.014 \\
\hline & $(-1.11)$ & $(1.9$ & $(-0.08)$ & & & & $(-0.73)$ & $(0.02)$ \\
\hline Australia & 0.003 & 0.019 & 13.2 & -3 & 0.5 & -1.3 & -0.1 & 0.024 \\
\hline All Ordinaries & $(0.08)$ & $(0.7$ & $(1.64)$ & & $(0.95)$ & & $(-0.85)$ & $(0.00)$ \\
\hline New Zealand & -0.116 & 0.036 & 21.2 & -20 & 0.3 & 0.0 & 0.1 & 0.008 \\
\hline Capital 40 & $(-1.80)$ & $(0.84)$ & $(1.05)$ & $(-3.11)$ & $(0.18)$ & $(-0.01)$ & $(0.59)$ & $(0.71)$ \\
\hline \multicolumn{9}{|c|}{ Panel C: Using data provided by Lisa Kramer, but restricting to period with daily weather from NOAA } \\
\hline Sweden & $-0.133^{*}$ & 0.023 & -9.1 & 16.0 & 0.5 & -0.1 & -41.9 & 0.031 \\
\hline Veckans Affärer & $(-2.21)$ & (1.56) & $(-1.81)$ & $(1.01)$ & $(0.34)$ & $(-0.38)$ & $(-1.41)$ & $(0.09)$ \\
\hline \multirow[t]{2}{*}{ U.K. FTSE 100} & -0.036 & $0.031 *$ & $-11.7^{* *}$ & 14.8 & -1.7 & -0.1 & -30.8 & 0.012 \\
\hline & $(-0.80)$ & $(2.06)$ & $(-3.00)$ & $(1.58)$ & & & $(-1.17)$ & $(0.43)$ \\
\hline \multirow{2}{*}{ Germany } & $-0.097 *$ & 0.023 & $-13.6 * *$ & 16.3 & -0.7 & 0.0 & 3.8 & 0.010 \\
\hline & $(-2.18)$ & $(1.21)$ & $(-3.60)$ & $(1.41)$ & $(-0.24)$ & & $(0.13)$ & $(0.05)$ \\
\hline \multirow[t]{2}{*}{ Canada } & -0.056 & $0.054^{* *}$ & $-10.7 * *$ & 1.3 & -0.4 & 0.2 & 27.9 & 0.026 \\
\hline & & $(2.78)$ & & & $(-0.9$ & & & $(0.32)$ \\
\hline \multirow[t]{2}{*}{ U.S. - S\&P500 } & -0.025 & 0.023 & $-15.3^{* *}$ & -0.7 & -0.1 & 0.0 & 6.8 & 0.018 \\
\hline & $(-0.99)$ & $(1.58)$ & $(-7.29)$ & & $(-0.23)$ & $(0.18)$ & $(0.44)$ & $(0.00)$ \\
\hline \multirow[t]{2}{*}{ U.S. - } & $-0.086 * *$ & $0.036 *$ & $-27.9 * *$ & $18.9 * *$ & -0.2 & 0.1 & 1.8 & 0.092 \\
\hline & & $(2.37)$ & & & & & $(0.11)$ & $(0.00)$ \\
\hline \multirow[t]{2}{*}{ U.S. - vwNASD } & $-0.133^{* *}$ & $0.071^{* *}$ & $-25.6^{* *}$ & 6.7 & -0.3 & 0.4 & 8.9 & 0.033 \\
\hline & $(-3.26)$ & $(2.96)$ & & $(0.72)$ & $(-0.61)$ & (1.36) & $(0.40)$ & $(0.24)$ \\
\hline \multirow[t]{2}{*}{ U.S. - vwNYSE } & -0.041 & 0.027 & $-12.5^{* *}$ & 1.3 & -0.1 & 0.0 & 4.6 & 0.029 \\
\hline & $(-1.43)$ & $(1.65)$ & & & $(-0.28)$ & & $(0.27)$ & $(0.71)$ \\
\hline \multirow[t]{2}{*}{ Japan } & -0.040 & 0.022 & $-7.6^{*}$ & -10.1 & -0.7 & -0.2 & 20.9 & 0.006 \\
\hline & $(-0.94)$ & $(0.70)$ & $(-2.15)$ & $(-0.94)$ & $(-1.69)$ & $(-0.86)$ & $(1.06)$ & $(0.02)$ \\
\hline South Africa & -0.040 & 0.095 & $-13.3^{* *}$ & -0.9 & 0.0 & 1.7 & -2.2 & 0.016 \\
\hline & $(-1.00)$ & $(1.41)$ & $(-3.03)$ & $(-0.08)$ & $(0.08)$ & (1.67) & $(-0.10)$ & $(0.24)$ \\
\hline Australia & 0.002 & 0.028 & -3.7 & 13.7 & $-0.5^{*}$ & 0.5 & -42.0 & 0.014 \\
\hline All Ordinaries & $(0.06)$ & $(0.85)$ & $(-1.10)$ & $(1.73)$ & $(-2.12)$ & $(0.73)$ & $(-1.29)$ & $(0.00)$ \\
\hline New Zealand & -0.126 & 0.056 & $-23.9 * *$ & 22.8 & 0.0 & 1.8 & 88.0 & 0.012 \\
\hline Capital 40 & $(-1.90)$ & $(1.30)$ & $(-3.14)$ & $(1.14)$ & $(0.07)$ & $(1.47)$ & $(0.82)$ & $(0.74)$ \\
\hline
\end{tabular}

* Significant at the two-sided 5 percent level

** Significant at the two-sided 1 percent level 
Patrick J. Kelly, Felix Meschke, Sentiment and stock returns: The SAD anomaly revisited, Journal of Banking \& Finance, June 2010, Volume 34.6:1308-1326. Publisher's official version: http://dx.doi.org/10.1016/j.jbankfin.2009.11.027. Open Access version: http://kuscholarworks.ku.edu/dspace/.

Table 3

Daily return regression on the fall dummy, SAD measure, and weather controls. Table 3 reports coefficients and (tstatistics) from a regression of daily index returns in percent using the return series described in Table 1 on a fall dummy, the SAD measure, tax and Monday dummies, and weather. Control variables coefficients are multiplied by 100. The last column reports the unadjusted R-squared on top and the p-value from a Ljung-Box (1978) chi-square test for autocorrelation up to ten lags in parentheses. The intercept and coefficients of lagged index returns (included to control for autocorrelation) are not reported to conserve space. t-statistics control for heteroskedasticity following MacKinnon and White (1985).

\begin{tabular}{|c|c|c|c|c|c|c|c|c|}
\hline Country & Fall & SAD & Tax & Monday & Temp & Cloud & Precip. & RSQ \\
\hline Finland & $\begin{array}{c}0.021 \\
(0.29)\end{array}$ & $\begin{array}{l}-0.006 \\
(-0.46)\end{array}$ & $\begin{array}{c}18.8 \\
(0.80)\end{array}$ & $\begin{array}{c}-1.0 \\
(-0.18)\end{array}$ & $\begin{array}{c}-0.8^{*} \\
(-2.27)\end{array}$ & $\begin{array}{c}-0.1 \\
(-0.05)\end{array}$ & $\begin{array}{c}-0.7 \\
(-1.03)\end{array}$ & $\begin{array}{c}18.8 \\
(0.80)\end{array}$ \\
\hline Iceland & $\begin{array}{l}-0.208^{*} \\
(-2.05)\end{array}$ & $\begin{array}{r}0.015 \\
(1.34)\end{array}$ & $\begin{array}{l}-13.3 \\
(-1.08)\end{array}$ & $\begin{array}{c}-8.3^{*} \\
(-2.06)\end{array}$ & $\begin{array}{c}0.5 \\
(1.34)\end{array}$ & $\begin{array}{c}0.1 \\
(0.14)\end{array}$ & $\begin{array}{c}0.4 \\
(0.81)\end{array}$ & $\begin{array}{c}-13.3 \\
(-1.08)\end{array}$ \\
\hline Norway & $\begin{array}{l}-0.131 * \\
(-2.39)\end{array}$ & $\begin{array}{c}0.011 \\
(1.01)\end{array}$ & $\begin{array}{l}35.7 * * \\
(2.75)\end{array}$ & $\begin{array}{c}-6.1 \\
(-1.32)\end{array}$ & $\begin{array}{c}-0.1 \\
(-0.47)\end{array}$ & $\begin{array}{c}-1.5 \\
(-1.94)\end{array}$ & $\begin{array}{c}-0.3 \\
(-0.87)\end{array}$ & $\begin{array}{c}35.7 * * \\
(2.75)\end{array}$ \\
\hline Sweden & -0.076 & 0.016 & 20.8 & -8.2 & -0.3 & -1.4 & 0.0 & 20.8 \\
\hline$O M X$ & $(-1.43)$ & (1.37) & (1.58) & $(-1.83)$ & $(-1.22)$ & $(-1.90)$ & $(-0.08)$ & (1.58) \\
\hline Sweden & -0.088 & 0.015 & 21.5 & -9.9 & -0.4 & -1.6 & -0.5 & 21.5 \\
\hline Veckans Affärer & $(-1.43)$ & $(1.12)$ & (1.39) & $(-1.90)$ & $(-1.53)$ & $(-1.84)$ & $(-0.57)$ & (1.39) \\
\hline Denmark & $\begin{array}{c}-0.063 \\
(-1.20)\end{array}$ & $\begin{array}{c}0.018 \\
(1.26)\end{array}$ & $\begin{array}{c}1.8 \\
(0.15)\end{array}$ & $\begin{array}{c}-3.9 \\
(-0.86)\end{array}$ & $\begin{array}{c}-0.1 \\
(-0.43)\end{array}$ & $\begin{array}{c}-0.7 \\
(-0.83)\end{array}$ & $\begin{array}{c}-1.0 \\
(-1.28)\end{array}$ & $\begin{array}{c}1.8 \\
(0.15)\end{array}$ \\
\hline Ireland & $\begin{array}{l}-0.124 * * \\
(-3.25)\end{array}$ & $\begin{array}{l}0.034^{* *} \\
(3.19)\end{array}$ & $\begin{array}{c}6.2 \\
(0.96)\end{array}$ & $\begin{array}{c}-1.6 \\
(-0.47)\end{array}$ & $\begin{array}{c}0.0 \\
(-0.02)\end{array}$ & $\begin{array}{c}0.2 \\
(0.28)\end{array}$ & $\begin{array}{c}0.0 \\
(-0.01)\end{array}$ & $\begin{array}{c}6.2 \\
(0.96)\end{array}$ \\
\hline Netherlands & $\begin{array}{c}-0.059 \\
(-1.36)\end{array}$ & $\begin{array}{c}0.010 \\
(0.76)\end{array}$ & $\begin{array}{c}11.7 \\
(1.18)\end{array}$ & $\begin{array}{c}-7.1 \\
(-1.91)\end{array}$ & $\begin{array}{l}-0.7 * * \\
(-2.61)\end{array}$ & $\begin{array}{l}-1.7 * * \\
(-2.75)\end{array}$ & $\begin{array}{c}0.0 \\
(0.11)\end{array}$ & $\begin{array}{c}11.7 \\
(1.18)\end{array}$ \\
\hline U.K. FTSE 100 & $\begin{array}{c}-0.029 \\
(-0.67)\end{array}$ & $\begin{array}{r}0.012 \\
(0.92)\end{array}$ & $\begin{array}{c}12.2 \\
(1.51)\end{array}$ & $\begin{array}{c}-7.5 \\
(-1.89)\end{array}$ & $\begin{array}{c}-0.6 \\
(-1.82)\end{array}$ & $\begin{array}{c}-0.8 \\
(-1.13)\end{array}$ & $\begin{array}{c}-0.1 \\
(-0.11)\end{array}$ & $\begin{array}{c}12.2 \\
(1.51)\end{array}$ \\
\hline U.K. - Total & $\begin{array}{l}-0.076^{*} \\
(-2.22)\end{array}$ & $\begin{array}{r}0.020 \\
(1.81)\end{array}$ & $\begin{array}{c}6.3 \\
(0.93)\end{array}$ & $\begin{array}{c}-14.2^{* *} \\
(-4.50)\end{array}$ & $\begin{array}{c}-0.6^{*} \\
(-2.31)\end{array}$ & $\begin{array}{c}-1.1 \\
(-1.76)\end{array}$ & $\begin{array}{c}-0.2 \\
(-0.56)\end{array}$ & $\begin{array}{c}6.3 \\
(0.93)\end{array}$ \\
\hline Belgium & $\begin{array}{l}-0.075^{*} \\
(-2.28)\end{array}$ & $\begin{array}{c}0.015 \\
(1.37)\end{array}$ & $\begin{array}{c}2.9 \\
(0.31)\end{array}$ & $\begin{array}{c}-4.0 \\
(-1.40)\end{array}$ & $\begin{array}{l}-0.6 * * \\
(-2.93)\end{array}$ & $\begin{array}{l}-1.3 * * \\
(-2.67)\end{array}$ & $\begin{array}{c}0.0 \\
(-0.27)\end{array}$ & $\begin{array}{c}2.9 \\
(0.31)\end{array}$ \\
\hline Germany & $\begin{array}{l}-0.091 * \\
(-2.09)\end{array}$ & $\begin{array}{r}0.022 \\
(1.44)\end{array}$ & $\begin{array}{c}14.8 \\
(1.32)\end{array}$ & $\begin{array}{c}-13.6^{* *} \\
(-3.53)\end{array}$ & $\begin{array}{c}-0.1 \\
(-0.58)\end{array}$ & $\begin{array}{c}-1.1 \\
(-1.76)\end{array}$ & $\begin{array}{c}0.1 \\
(0.14)\end{array}$ & $\begin{array}{c}14.8 \\
(1.32)\end{array}$ \\
\hline Austria & $\begin{array}{l}-0.076^{*} \\
(-2.49)\end{array}$ & $\begin{array}{r}0.019 \\
(1.50)\end{array}$ & $\begin{array}{c}-1.5 \\
(-0.18)\end{array}$ & $\begin{array}{c}1.7 \\
(0.61)\end{array}$ & $\begin{array}{c}-0.3 \\
(-1.87)\end{array}$ & $\begin{array}{c}-0.8 \\
(-1.67)\end{array}$ & $\begin{array}{c}-0.2 \\
(-1.29)\end{array}$ & $\begin{array}{c}-1.5 \\
(-0.18)\end{array}$ \\
\hline Switzerland & $\begin{array}{c}-0.028 \\
(-0.82)\end{array}$ & $\begin{array}{c}0.011 \\
(0.82)\end{array}$ & $\begin{array}{c}12.6 \\
(1.57)\end{array}$ & $\begin{array}{l}-9.6 * * \\
(-3.09)\end{array}$ & $\begin{array}{l}-0.4^{*} \\
(-2.07)\end{array}$ & $\begin{array}{c}-0.6 \\
(-1.08)\end{array}$ & $\begin{array}{c}-0.3 \\
(-1.06)\end{array}$ & $\begin{array}{c}12.6 \\
(1.57)\end{array}$ \\
\hline France & $\begin{array}{l}-0.077 * \\
(-2.05)\end{array}$ & $\begin{array}{c}0.014 \\
(0.92)\end{array}$ & $\begin{array}{c}5.3 \\
(0.54)\end{array}$ & $\begin{array}{c}-12.8 * * \\
(-3.77)\end{array}$ & $\begin{array}{l}-0.7 * * \\
(-2.69)\end{array}$ & $\begin{array}{l}-1.4^{*} \\
(-2.51)\end{array}$ & $\begin{array}{c}-0.1 \\
(-0.24)\end{array}$ & $\begin{array}{c}5.3 \\
(0.54)\end{array}$ \\
\hline Canada & $\begin{array}{l}-0.080^{*} \\
(-2.20)\end{array}$ & $\begin{array}{l}0.048^{* *} \\
(3.10)\end{array}$ & $\begin{array}{c}-2.3 \\
(-0.29)\end{array}$ & $\begin{array}{l}-9.0 * * \\
(-2.99)\end{array}$ & $\begin{array}{c}0.1 \\
(0.57)\end{array}$ & $\begin{array}{c}-0.4 \\
(-0.76)\end{array}$ & $\begin{array}{c}-0.1 \\
(-1.44)\end{array}$ & $\begin{array}{c}-2.3 \\
(-0.29)\end{array}$ \\
\hline Italy & $\begin{array}{l}-0.129 * * \\
(-3.05)\end{array}$ & $\begin{array}{l}0.046^{*} \\
(2.25)\end{array}$ & $\begin{array}{c}-6.2 \\
(-0.65)\end{array}$ & $\begin{array}{c}-13.9 * * \\
(-3.48)\end{array}$ & $\begin{array}{c}-0.5 \\
(-1.85)\end{array}$ & $\begin{array}{c}0.1 \\
(0.19)\end{array}$ & $\begin{array}{c}0.3 \\
(1.14)\end{array}$ & $\begin{array}{c}-6.2 \\
(-0.65)\end{array}$ \\
\hline U.S. - DJIA & $\begin{array}{c}-0.022 \\
(-0.94)\end{array}$ & $\begin{array}{c}0.022 \\
(1.96)\end{array}$ & $\begin{array}{c}3.9 \\
(0.67)\end{array}$ & $\begin{array}{c}-10.5^{* *} \\
(-4.94)\end{array}$ & $\begin{array}{c}0.0 \\
(0.11)\end{array}$ & $\begin{array}{c}-0.7^{*} \\
(-2.47)\end{array}$ & $\begin{array}{c}-0.3 \\
(-1.73)\end{array}$ & $\begin{array}{c}3.9 \\
(0.67)\end{array}$ \\
\hline U.S. - S\&P500 & $\begin{array}{r}-0.021 \\
(-0.88)\end{array}$ & $\begin{array}{c}0.020 \\
(1.79)\end{array}$ & $\begin{array}{c}-1.1 \\
(-0.19)\end{array}$ & $\begin{array}{c}-14.9 * * \\
(-6.98)\end{array}$ & $\begin{array}{c}0.0 \\
(-0.44)\end{array}$ & $\begin{array}{l}-0.8 * * \\
(-2.60)\end{array}$ & $\begin{array}{c}-0.1 \\
(-0.56)\end{array}$ & $\begin{array}{c}-1.1 \\
(-0.19)\end{array}$ \\
\hline U.S. - ewAMEX & $\begin{array}{l}-0.103^{* *} \\
(-5.20)\end{array}$ & $\begin{array}{l}0.035^{* *} \\
(3.51)\end{array}$ & $\begin{array}{l}45.9 * * \\
(6.33)\end{array}$ & $\begin{array}{l}-32.8^{* *} \\
(-16.33)\end{array}$ & $\begin{array}{c}-0.1 \\
(-0.99)\end{array}$ & $\begin{array}{l}-0.8 * * \\
(-2.87)\end{array}$ & $\begin{array}{c}-0.1 \\
(-0.80)\end{array}$ & $\begin{array}{c}45.9^{* *} \\
(6.33)\end{array}$ \\
\hline U.S. - ewNASD & $\begin{array}{l}-0.111^{* *} \\
(-4.56)\end{array}$ & $\begin{array}{l}0.039^{* *} \\
(3.20)\end{array}$ & $\begin{array}{c}27.1^{* *} \\
(4.01)\end{array}$ & $\begin{array}{l}-30.9 * * \\
(-13.74)\end{array}$ & $\begin{array}{c}-0.1 \\
(-0.81)\end{array}$ & $\begin{array}{c}-0.7^{*} \\
(-2.21)\end{array}$ & $\begin{array}{c}0.0 \\
(-0.17)\end{array}$ & $\begin{array}{l}27.1^{* *} \\
(4.01)\end{array}$ \\
\hline U.S. - ewNYSE & $\begin{array}{l}-0.059 * * \\
(-2.90)\end{array}$ & $\begin{array}{l}0.029 * * \\
(2.99)\end{array}$ & $\begin{array}{r}19.0 * * \\
(3.47)\end{array}$ & $\begin{array}{l}-22.9 * * \\
(-11.97)\end{array}$ & $\begin{array}{c}-0.1 \\
(-1.02)\end{array}$ & $\begin{array}{l}-0.8 * * \\
(-3.16)\end{array}$ & $\begin{array}{c}0.0 \\
(-0.19)\end{array}$ & $\begin{array}{r}19.0 \text { ** } \\
(0.00)\end{array}$ \\
\hline
\end{tabular}


Patrick J. Kelly, Felix Meschke, Sentiment and stock returns: The SAD anomaly revisited, Journal of Banking \& Finance, June 2010, Volume 34.6:1308-1326. Publisher's official version: http://dx.doi.org/10.1016/j.jbankfin.2009.11.027. Open Access version: http://kuscholarworks.ku.edu/dspace/.

\begin{tabular}{|c|c|c|c|c|c|c|c|c|}
\hline Country & Fall & SAD & Tax & Monday & Temp & Cloud & Precip. & RSQ \\
\hline U.S. - vwAMEX & $\begin{array}{l}-0.080^{* *} \\
(-3.30)\end{array}$ & $\begin{array}{l}0.037^{* *} \\
(3.03)\end{array}$ & $\begin{array}{c}12.8 \\
(1.90)\end{array}$ & $\begin{array}{l}-28.4^{* *} \\
(-12.13)\end{array}$ & $\begin{array}{c}-0.1 \\
(-0.54)\end{array}$ & $\begin{array}{c}-0.8^{*} \\
(-2.32)\end{array}$ & $\begin{array}{c}0.0 \\
(-0.10)\end{array}$ & $\begin{array}{r}0.073 \\
(0.00)\end{array}$ \\
\hline U.S. - vwNASD & $\begin{array}{l}-0.096 * \\
(-2.44)\end{array}$ & $\begin{array}{l}0.057^{* *} \\
(2.84)\end{array}$ & $\begin{array}{c}7.0 \\
(0.56)\end{array}$ & $\begin{array}{c}-21.6^{* *} \\
(-6.07)\end{array}$ & $\begin{array}{c}0.1 \\
(0.78)\end{array}$ & $\begin{array}{c}-1.1^{*} \\
(-2.11)\end{array}$ & $\begin{array}{c}0.1 \\
(0.27)\end{array}$ & $\begin{array}{r}0.013 \\
(0.01)\end{array}$ \\
\hline U.S. - vwNYSE & $\begin{array}{c}-0.022 \\
(-1.01)\end{array}$ & $\begin{array}{c}0.019 \\
(1.87)\end{array}$ & $\begin{array}{c}-0.7 \\
(-0.12)\end{array}$ & $\begin{array}{c}-16.0 * * \\
(-7.95)\end{array}$ & $\begin{array}{c}-0.1 \\
(-0.74)\end{array}$ & $\begin{array}{l}-0.7 * * \\
(-2.72)\end{array}$ & $\begin{array}{c}-0.1 \\
(-0.68)\end{array}$ & $\begin{array}{r}0.017 \\
(0.39)\end{array}$ \\
\hline China & $\begin{array}{r}0.000 \\
(0.00)\end{array}$ & $\begin{array}{c}-0.108 \\
(-1.36)\end{array}$ & $\begin{array}{c}43.7 \\
(1.84)\end{array}$ & $\begin{array}{l}-16.1 \\
(-1.26)\end{array}$ & $\begin{array}{c}-0.8 \\
(-1.24)\end{array}$ & $\begin{array}{c}0.9 \\
(0.53)\end{array}$ & $\begin{array}{c}0.2 \\
(0.19)\end{array}$ & $\begin{array}{r}0.005 \\
(0.00)\end{array}$ \\
\hline Spain & $\begin{array}{c}-0.066 \\
(-1.55)\end{array}$ & $\begin{array}{c}0.021 \\
(1.02)\end{array}$ & $\begin{array}{c}5.8 \\
(0.60)\end{array}$ & $\begin{array}{c}7.9 \\
(1.88)\end{array}$ & $\begin{array}{l}-0.5^{*} \\
(-2.17)\end{array}$ & $\begin{array}{c}-0.6 \\
(-1.15)\end{array}$ & $\begin{array}{c}0.2 \\
(1.40)\end{array}$ & $\begin{array}{r}0.016 \\
(0.00)\end{array}$ \\
\hline Greece & $\begin{array}{l}-0.174^{*} \\
(-2.31)\end{array}$ & $\begin{array}{c}0.035 \\
(0.87)\end{array}$ & $\begin{array}{l}35.2^{*} \\
(2.03)\end{array}$ & $\begin{array}{l}-17.1^{*} \\
(-2.32)\end{array}$ & $\begin{array}{c}0.1 \\
(0.11)\end{array}$ & $\begin{array}{c}1.7 \\
(1.47)\end{array}$ & $\begin{array}{c}1.0 \\
(1.31)\end{array}$ & $\begin{array}{c}0.032 \\
(0.36)\end{array}$ \\
\hline Turkey & $\begin{array}{c}0.028 \\
(0.27)\end{array}$ & $\begin{array}{c}0.089 \\
(1.47)\end{array}$ & $\begin{array}{c}44.2 \\
(1.46)\end{array}$ & $\begin{array}{c}-30.7 * * \\
(-2.99)\end{array}$ & $\begin{array}{c}0.2 \\
(0.28)\end{array}$ & $\begin{array}{c}0.5 \\
(0.27)\end{array}$ & $\begin{array}{c}-1.1 \\
(-1.16)\end{array}$ & $\begin{array}{r}0.012 \\
(0.13)\end{array}$ \\
\hline Korea & $\begin{array}{c}0.015 \\
(0.25)\end{array}$ & $\begin{array}{c}0.002 \\
(0.05)\end{array}$ & $\begin{array}{c}-7.1 \\
(-0.34)\end{array}$ & $\begin{array}{c}3.1 \\
(0.56)\end{array}$ & $\begin{array}{c}-0.3 \\
(-0.89)\end{array}$ & $\begin{array}{c}-0.3 \\
(-0.45)\end{array}$ & $\begin{array}{c}0.1 \\
(1.56)\end{array}$ & $\begin{array}{r}0.007 \\
(0.00)\end{array}$ \\
\hline Japan & $\begin{array}{l}-0.049 \\
(-1.20)\end{array}$ & $\begin{array}{c}0.008 \\
(0.30)\end{array}$ & $\begin{array}{c}2.8 \\
(0.31)\end{array}$ & $\begin{array}{c}-5.5 \\
(-1.57)\end{array}$ & $\begin{array}{c}-0.2 \\
(-1.09)\end{array}$ & $\begin{array}{l}-1.2^{*} \\
(-2.23)\end{array}$ & $\begin{array}{c}-0.2 \\
(-1.02)\end{array}$ & $\begin{array}{c}0.004 \\
(0.01)\end{array}$ \\
\hline Jordan & $\begin{array}{c}0.060 \\
(1.10)\end{array}$ & $\begin{array}{l}-0.016 \\
(-0.37)\end{array}$ & $\begin{array}{l}42.2^{* *} \\
(3.09)\end{array}$ & $\begin{array}{c}2.6 \\
(0.49)\end{array}$ & $\begin{array}{c}0.1 \\
(0.28)\end{array}$ & $\begin{array}{c}1.3 \\
(1.27)\end{array}$ & $\begin{array}{c}0.1 \\
(0.15)\end{array}$ & $\begin{array}{c}0.021 \\
(0.02)\end{array}$ \\
\hline Mexico & $\begin{array}{c}-0.158^{*} \\
(-1.97)\end{array}$ & $\begin{array}{r}0.117 \\
(1.50)\end{array}$ & $\begin{array}{c}-12.4 \\
(-0.62)\end{array}$ & $\begin{array}{c}0.9 \\
(0.13)\end{array}$ & $\begin{array}{c}-0.3 \\
(-0.32)\end{array}$ & $\begin{array}{c}-0.2 \\
(-0.13)\end{array}$ & $\begin{array}{c}0.9 \\
(0.81)\end{array}$ & $\begin{array}{c}0.032 \\
(0.01)\end{array}$ \\
\hline Taiwan & $\begin{array}{l}-0.223 * * \\
(-2.81)\end{array}$ & $\begin{array}{c}0.134 \\
(1.47)\end{array}$ & $\begin{array}{c}14.1 \\
(0.74)\end{array}$ & $\begin{array}{c}9.5 \\
(1.20)\end{array}$ & $\begin{array}{c}-0.7 \\
(-0.96)\end{array}$ & $\begin{array}{c}-2.1 \\
(-1.52)\end{array}$ & $\begin{array}{c}0.0 \\
(0.21)\end{array}$ & $\begin{array}{c}0.011 \\
(0.12)\end{array}$ \\
\hline Hong Kong & $\begin{array}{l}-0.155^{*} \\
(-2.36)\end{array}$ & $\begin{array}{l}0.192^{*} \\
(2.53)\end{array}$ & $\begin{array}{c}-5.7 \\
(-0.44)\end{array}$ & $\begin{array}{l}-15.8^{*} \\
(-2.36)\end{array}$ & $\begin{array}{c}0.1 \\
(0.23)\end{array}$ & $\begin{array}{c}-0.2 \\
(-0.19)\end{array}$ & $\begin{array}{c}-0.1 \\
(-0.92)\end{array}$ & $\begin{array}{c}0.008 \\
(0.00)\end{array}$ \\
\hline India & $\begin{array}{c}-0.154 \\
(-1.89)\end{array}$ & $\begin{array}{l}0.251^{*} \\
(2.28)\end{array}$ & $\begin{array}{c}25.4 \\
(1.18)\end{array}$ & $\begin{array}{c}6.7 \\
(0.86)\end{array}$ & $\begin{array}{c}0.5 \\
(0.34)\end{array}$ & $\begin{array}{c}1.8 \\
(1.32)\end{array}$ & $\begin{array}{c}0.1 \\
(0.56)\end{array}$ & $\begin{array}{r}0.017 \\
(0.39)\end{array}$ \\
\hline Thailand & $\begin{array}{l}-0.044 \\
(-0.87)\end{array}$ & $\begin{array}{r}0.061 \\
(0.63)\end{array}$ & $\begin{array}{c}20.9 \\
(1.42)\end{array}$ & $\begin{array}{l}-30.1 * * \\
(-6.15)\end{array}$ & $\begin{array}{c}-1.3 \\
(-1.10)\end{array}$ & $\begin{array}{c}1.0 \\
(0.69)\end{array}$ & $\begin{array}{c}-0.2 \\
(-1.19)\end{array}$ & $\begin{array}{r}0.035 \\
(0.35)\end{array}$ \\
\hline Philippines & $\begin{array}{l}-0.067 \\
(-0.84)\end{array}$ & $\begin{array}{c}0.186 \\
(1.20)\end{array}$ & $\begin{array}{c}8.3 \\
(0.39)\end{array}$ & $\begin{array}{l}-14.9 * \\
(-2.07)\end{array}$ & $\begin{array}{c}-1.6 \\
(-0.96)\end{array}$ & $\begin{array}{c}-3.2 \\
(-1.49)\end{array}$ & $\begin{array}{c}0.4 \\
(0.89)\end{array}$ & $\begin{array}{r}0.032 \\
(0.07)\end{array}$ \\
\hline Sri Lanka & $\begin{array}{l}-0.020 \\
(-0.41)\end{array}$ & $\begin{array}{c}0.188 \\
(0.83)\end{array}$ & $\begin{array}{c}4.0 \\
(0.29)\end{array}$ & $\begin{array}{c}-0.6 \\
(-0.14)\end{array}$ & $\begin{array}{c}-0.9 \\
(-1.10)\end{array}$ & $\begin{array}{l}-2.1^{*} \\
(-2.26)\end{array}$ & $\begin{array}{c}0.3 \\
(1.25)\end{array}$ & $\begin{array}{c}0.181 \\
(0.90)\end{array}$ \\
\hline Malaysia & $\begin{array}{c}0.005 \\
(0.10)\end{array}$ & $\begin{array}{r}0.150 \\
(0.31)\end{array}$ & $\begin{array}{c}2.6 \\
(0.23)\end{array}$ & $\begin{array}{l}-21.9 * * \\
(-4.59)\end{array}$ & $\begin{array}{c}1.5 \\
(0.80)\end{array}$ & $\begin{array}{c}-6.3 \\
(-1.20)\end{array}$ & $\begin{array}{c}-0.4 \\
(-1.62)\end{array}$ & $\begin{array}{c}0.018 \\
(0.11)\end{array}$ \\
\hline Singapore & $\begin{array}{l}-0.085 \\
(-1.96)\end{array}$ & $\begin{array}{c}-0.549 \\
(-1.47)\end{array}$ & $\begin{array}{l}26.0 * \\
(2.50)\end{array}$ & $\begin{array}{c}-16.9 * * \\
(-4.02)\end{array}$ & $\begin{array}{c}-0.8 \\
(-0.72)\end{array}$ & $\begin{array}{c}-1.9 \\
(-0.98)\end{array}$ & $\begin{array}{c}-0.2 \\
(-1.44)\end{array}$ & $\begin{array}{r}0.015 \\
(0.01)\end{array}$ \\
\hline Indonesia & $\begin{array}{c}0.077 \\
(1.51)\end{array}$ & $\begin{array}{l}-0.262 \\
(-1.87)\end{array}$ & $\begin{array}{c}2.2 \\
(0.13)\end{array}$ & $\begin{array}{l}-10.0 \\
(-1.75)\end{array}$ & $\begin{array}{c}-0.8 \\
(-0.95)\end{array}$ & $\begin{array}{c}0.1 \\
(0.05)\end{array}$ & $\begin{array}{l}-0.4^{*} \\
(-2.55)\end{array}$ & $\begin{array}{r}0.090 \\
(0.00)\end{array}$ \\
\hline South Africa & $\begin{array}{l}-0.045 \\
(-1.25)\end{array}$ & $\begin{array}{l}0.088^{*} \\
(2.02)\end{array}$ & $\begin{array}{c}-4.4 \\
(-0.44)\end{array}$ & $\begin{array}{c}-10.5 * * \\
(-2.67)\end{array}$ & $\begin{array}{c}1.3^{*} \\
(2.29)\end{array}$ & $\begin{array}{c}0.8 \\
(0.99)\end{array}$ & $\begin{array}{c}-0.1 \\
(-0.74)\end{array}$ & $\begin{array}{r}0.015 \\
(0.07)\end{array}$ \\
\hline $\begin{array}{l}\text { Australia } \\
\text { All Ordinaries }\end{array}$ & $\begin{array}{r}0.016 \\
(0.57)\end{array}$ & $\begin{array}{r}0.012 \\
(0.56)\end{array}$ & $\begin{array}{l}10.7 \\
(1.54)\end{array}$ & $\begin{array}{c}0.2 \\
(0.05)\end{array}$ & $\begin{array}{c}0.4 \\
(1.07)\end{array}$ & $\begin{array}{l}-1.1^{*} \\
(-2.28)\end{array}$ & $\begin{array}{c}-0.2 \\
(-1.09)\end{array}$ & $\begin{array}{r}0.010 \\
(0.00)\end{array}$ \\
\hline Australia & 0.009 & 0.010 & 12.6 & -2.9 & 0.7 & -0.8 & -0.3 & 0.016 \\
\hline Total Market & $(0.29)$ & $(0.46)$ & $(1.88)$ & $(-0.93)$ & $(1.71)$ & $(-1.65)$ & $(-1.70)$ & $(0.00)$ \\
\hline $\begin{array}{l}\text { New Zealand } \\
\text { Capital } 40\end{array}$ & $\begin{array}{r}-0.048 \\
(-0.91)\end{array}$ & $\begin{array}{r}0.018 \\
(0.52)\end{array}$ & $\begin{array}{c}18.5 \\
(1.18)\end{array}$ & $\begin{array}{l}-12.8^{*} \\
(-2.53)\end{array}$ & $\begin{array}{c}0.4 \\
(0.32)\end{array}$ & $\begin{array}{c}-0.3 \\
(-0.22)\end{array}$ & $\begin{array}{c}0.0 \\
(0.11)\end{array}$ & $\begin{array}{r}0.004 \\
(0.40)\end{array}$ \\
\hline $\begin{array}{l}\text { New Zealand } \\
\text { FTSE }\end{array}$ & $\begin{array}{l}-0.054 \\
(-1.08)\end{array}$ & $\begin{array}{c}0.005 \\
(0.17)\end{array}$ & $\begin{array}{l}31.7^{*} \\
(2.53)\end{array}$ & $\begin{array}{l}-9.7 * \\
(-2.15)\end{array}$ & $\begin{array}{c}0.1 \\
(0.16)\end{array}$ & $\begin{array}{c}0.1 \\
(0.12)\end{array}$ & $\begin{array}{c}0.0 \\
(0.29)\end{array}$ & $\begin{array}{r}0.004 \\
(0.22)\end{array}$ \\
\hline
\end{tabular}

* Significant at the two-sided 5 percent level

** Significant at the two-sided 1 percent level 


\section{Table 4}

Correlation between prevalence of SAD in the general population, latitude, fall dummy and SAD coefficients. This table reports pairwise correlations between the fall dummy and SAD coefficients from Table 3, prevalence of Seasonal Affective Disorder, and latitude. The prevalence data for 18 countries come from general population surveys listed in Appendix A, and latitude denotes the geographic location of each country's stock exchange (Column 3 of Table 1). Where there is more than one study per country, we average the prevalence of SAD across studies. Where there is more than one index, we average the coefficients on the fall dummy and SAD across indices. The Onset measure is from Kamstra et al (2007). Pearson correlations are displayed above the diagonal, and Spearman rank correlations below the diagonal. p-values for the correlations are in parentheses with the count of the number of pairs below.

\begin{tabular}{|c|c|c|c|c|c|c|c|}
\hline & \multicolumn{7}{|c|}{ Pearson Correlation } \\
\hline & Fall & SAD & Onset & Prevalence & $\begin{array}{l}\text { Sub- } \\
\text { Syndromal }\end{array}$ & $\begin{array}{l}\text { Sum } \\
\text { Prevalence }\end{array}$ & Degree \\
\hline \multirow[t]{3}{*}{ Fall Coefficient } & & -0.14 & 0.65 & 0.03 & -0.09 & -0.04 & -0.18 \\
\hline & & $(0.572)$ & $(0.003)$ & $(0.919)$ & $(0.742)$ & $(0.884)$ & $(0.307)$ \\
\hline & & 18 & 18 & 18 & 17 & 17 & 36 \\
\hline \multirow[t]{3}{*}{ SAD Coefficient } & -0.33 & & 0.23 & -0.27 & -0.26 & -0.31 & 0.05 \\
\hline & $(0.185)$ & & $(0.358)$ & $(0.281)$ & $(0.314)$ & $(0.225)$ & $(0.781)$ \\
\hline & 18 & & 18 & 18 & 17 & 17 & 36 \\
\hline \multirow[t]{3}{*}{ Onset } & 0.66 & 0.12 & & 0.19 & 0.07 & 0.17 & -0.16 \\
\hline & $(0.003)$ & $(0.639)$ & & $(0.451)$ & $(0.787)$ & $(0.503)$ & $(0.358)$ \\
\hline & 18 & 18 & & 18 & 17 & 17 & 36 \\
\hline Prevalence of SAD & -0.02 & -0.17 & 0.28 & & 0.30 & 0.76 & 0.44 \\
\hline \multirow[t]{2}{*}{ in General Population } & $(0.932)$ & $(0.499)$ & $(0.254)$ & & $(0.246)$ & $(0.000)$ & $(0.064)$ \\
\hline & 18 & 18 & 18 & & 17 & 17 & 18 \\
\hline Prevalence of Sub- & -0.07 & -0.09 & 0.12 & 0.44 & & 0.85 & 0.66 \\
\hline Syndromal SAD in General & $(0.804)$ & $(0.743)$ & $(0.639)$ & $(0.080)$ & & $(0.000)$ & $(0.004)$ \\
\hline Population & 17 & 17 & 17 & 17 & & 17 & 17 \\
\hline \multirow[t]{3}{*}{ Sum of SAD Prevalence } & -0.03 & -0.04 & 0.32 & 0.82 & 0.81 & & 0.67 \\
\hline & $(0.918)$ & $(0.881)$ & $(0.205)$ & $(0.000)$ & $(0.000)$ & & $(0.004)$ \\
\hline & 17 & 17 & 17 & 17 & 17 & & 17 \\
\hline \multirow[t]{4}{*}{ Degree of Latitude } & -0.19 & -0.32 & -0.25 & 0.48 & 0.63 & 0.55 & \\
\hline & $(0.259)$ & $(0.061)$ & $(0.139)$ & $(0.042)$ & $(0.007)$ & $(0.023)$ & \\
\hline & 36 & 36 & 36 & 18 & 17 & 17 & \\
\hline & \multicolumn{7}{|c|}{ Spearman Rank Correlation } \\
\hline
\end{tabular}


Patrick J. Kelly, Felix Meschke, Sentiment and stock returns: The SAD anomaly revisited, Journal of Banking \& Finance, June 2010, Volume 34.6:1308-1326. Publisher's official version: http://dx.doi.org/10.1016/j.jbankfin.2009.11.027. Open Access version: http://kuscholarworks.ku.edu/dspace/.

Table 5

Daily return regression on the fall dummy, a fall SAD measure, a winter SAD measure, and weather controls. The regression model in this table is identical to the model in Table 3, except that it replaces the SAD measure with fallSAD and winSAD. fallSAD is the SAD measure which is zero outside of fall and winSAD is the SAD measure, but zero outside of winter. Control variables coefficients are multiplied by 100 . The last column reports the unadjusted R-squared on top and the p-value from a Ljung-Box (1978) chi-square test for autocorrelation up to ten lags. Lagged index returns are included to control for autocorrelation. The intercept and coefficients on lagged returns are not reported to conserve space. t-stats control for heteroskedasticity following MacKinnon and White (1985).

\begin{tabular}{|c|c|c|c|c|c|c|c|c|c|}
\hline Country & Fall & $\begin{array}{c}\text { fall } \\
\text { SAD }\end{array}$ & $\begin{array}{l}\text { win } \\
\text { SAD }\end{array}$ & $\operatorname{Tax}$ & Monday & Temp & Cloud & Precip. & RSQ \\
\hline Finland & $\begin{array}{r}0.102 \\
(0.82)\end{array}$ & $\begin{array}{r}-0.020 \\
(-0.94)\end{array}$ & $\begin{array}{c}0.002 \\
(0.16)\end{array}$ & $\begin{array}{c}14.1 \\
(0.59)\end{array}$ & $\begin{array}{c}-1.1 \\
(-0.18)\end{array}$ & $\begin{array}{c}-0.7^{*} \\
(-2.04)\end{array}$ & $\begin{array}{c}-0.1 \\
(-0.08)\end{array}$ & $\begin{array}{c}-0.7 \\
(-1.02)\end{array}$ & $\begin{array}{c}0.002 \\
(0.02)\end{array}$ \\
\hline Iceland & $\begin{array}{r}-0.216 \\
(-1.15)\end{array}$ & $\begin{array}{r}0.017 \\
(0.57)\end{array}$ & $\begin{array}{c}0.015 \\
(1.96)\end{array}$ & $\begin{array}{l}-12.9 \\
(-1.14)\end{array}$ & $\begin{array}{c}-8.3^{*} \\
(-2.07)\end{array}$ & $\begin{array}{c}0.5 \\
(1.46)\end{array}$ & $\begin{array}{c}0.1 \\
(0.14)\end{array}$ & $\begin{array}{c}0.4 \\
(0.81)\end{array}$ & $\begin{array}{r}0.010 \\
(0.84)\end{array}$ \\
\hline Norway & $\begin{array}{c}-0.156 \\
(-1.74)\end{array}$ & $\begin{array}{c}0.016 \\
(0.92)\end{array}$ & $\begin{array}{c}0.008 \\
(0.67)\end{array}$ & $\begin{array}{l}37.1^{* *} \\
(2.80)\end{array}$ & $\begin{array}{c}-6.1 \\
(-1.31)\end{array}$ & $\begin{array}{c}-0.1 \\
(-0.53)\end{array}$ & $\begin{array}{c}-1.5 \\
(-1.95)\end{array}$ & $\begin{array}{c}-0.3 \\
(-0.87)\end{array}$ & $\begin{array}{r}0.010 \\
(0.02)\end{array}$ \\
\hline Sweden & $\begin{array}{l}-0.038 \\
(-0.43)\end{array}$ & 0.007 & 0.021 & 18.8 & $\begin{array}{c}-8.2 \\
(-1.83)\end{array}$ & $\begin{array}{c}-0.3 \\
(-111)\end{array}$ & $\begin{array}{c}-1.4 \\
(-1.92)\end{array}$ & $\begin{array}{c}0.0 \\
(-008)\end{array}$ & 0.023 \\
\hline $\begin{array}{l}O M X \\
\text { Sweden }\end{array}$ & $\begin{array}{l}(-0.43) \\
-0.070\end{array}$ & $\begin{array}{r}(0.37) \\
0.011\end{array}$ & $\begin{array}{c}(1.67) \\
0.017\end{array}$ & $\begin{array}{c}(1.41) \\
20.6\end{array}$ & $\begin{array}{c}(-1.83) \\
-9.9\end{array}$ & $\begin{array}{c}(-1.11) \\
-0.4\end{array}$ & $\begin{array}{c}(-1.92) \\
-1.6\end{array}$ & $\begin{array}{c}(-0.08) \\
-0.5\end{array}$ & $\begin{array}{r}(0.12) \\
0.026\end{array}$ \\
\hline Veckans Affärer & $(-0.68)$ & $(0.47)$ & $(1.22)$ & $(1.32)$ & $(-1.90)$ & $(-1.49)$ & $(-1.85)$ & $(-0.57)$ & $(0.00)$ \\
\hline Denmark & $\begin{array}{r}0.030 \\
(0.33)\end{array}$ & $\begin{array}{r}-0.007 \\
(-0.27)\end{array}$ & $\begin{array}{l}0.031 * \\
(2.03)\end{array}$ & $\begin{array}{c}-2.9 \\
(-0.24)\end{array}$ & $\begin{array}{c}-3.9 \\
(-0.87)\end{array}$ & $\begin{array}{c}-0.1 \\
(-0.20)\end{array}$ & $\begin{array}{c}-0.7 \\
(-0.85)\end{array}$ & $\begin{array}{c}-1.0 \\
(-1.29)\end{array}$ & $\begin{array}{r}0.007 \\
(0.00)\end{array}$ \\
\hline Ireland & $\begin{array}{c}-0.045 \\
(-0.65)\end{array}$ & $\begin{array}{c}0.009 \\
(0.45)\end{array}$ & $\begin{array}{c}0.043 * * \\
(3.77)\end{array}$ & $\begin{array}{c}7.2 \\
(1.11)\end{array}$ & $\begin{array}{c}-1.6 \\
(-0.47)\end{array}$ & $\begin{array}{c}0.0 \\
(0.13)\end{array}$ & $\begin{array}{c}0.2 \\
(0.27)\end{array}$ & $\begin{array}{c}0.0 \\
(-0.04)\end{array}$ & $\begin{array}{r}0.022 \\
(0.00)\end{array}$ \\
\hline Netherlands & $\begin{array}{c}-0.074 \\
(-1.00)\end{array}$ & $\begin{array}{c}0.015 \\
(0.66)\end{array}$ & $\begin{array}{c}0.008 \\
(0.54)\end{array}$ & $\begin{array}{c}12.4 \\
(1.24)\end{array}$ & $\begin{array}{c}-7.1 \\
(-1.91)\end{array}$ & $\begin{array}{l}-0.7 * * \\
(-2.63)\end{array}$ & $\begin{array}{l}-1.7 * * \\
(-2.74)\end{array}$ & $\begin{array}{c}0.0 \\
(0.12)\end{array}$ & $\begin{array}{c}0.004 \\
(0.00)\end{array}$ \\
\hline U.K. FTSE 100 & $\begin{array}{c}-0.004 \\
(-0.05)\end{array}$ & $\begin{array}{c}0.003 \\
(0.14)\end{array}$ & $\begin{array}{c}0.015 \\
(1.08)\end{array}$ & $\begin{array}{c}12.5 \\
(1.54)\end{array}$ & $\begin{array}{c}-7.5 \\
(-1.90)\end{array}$ & $\begin{array}{c}-0.6 \\
(-1.76)\end{array}$ & $\begin{array}{c}-0.8 \\
(-1.13)\end{array}$ & $\begin{array}{c}-0.1 \\
(-0.12)\end{array}$ & $\begin{array}{r}0.005 \\
(0.00)\end{array}$ \\
\hline U.K. - Total & $\begin{array}{r}-0.040 \\
(-0.65)\end{array}$ & $\begin{array}{r}0.007 \\
(0.38)\end{array}$ & $\begin{array}{c}0.024^{*} \\
(2.03)\end{array}$ & $\begin{array}{c}6.7 \\
(0.99)\end{array}$ & $\begin{array}{c}-14.2 * * \\
(-4.50)\end{array}$ & $\begin{array}{c}-0.6^{*} \\
(-2.23)\end{array}$ & $\begin{array}{c}-1.1 \\
(-1.78)\end{array}$ & $\begin{array}{c}-0.2 \\
(-0.56)\end{array}$ & $\begin{array}{c}0.011 \\
(0.00)\end{array}$ \\
\hline Belgium & $\begin{array}{c}-0.065 \\
(-1.16)\end{array}$ & $\begin{array}{c}0.011 \\
(0.62)\end{array}$ & $\begin{array}{r}0.017 \\
(1.38)\end{array}$ & $\begin{array}{c}2.5 \\
(0.25)\end{array}$ & $\begin{array}{c}-4.0 \\
(-1.40)\end{array}$ & $\begin{array}{l}-0.6^{* *} \\
(-2.90)\end{array}$ & $\begin{array}{l}-1.3 * * \\
(-2.67)\end{array}$ & $\begin{array}{c}0.0 \\
(-0.27)\end{array}$ & $\begin{array}{r}0.016 \\
(0.00)\end{array}$ \\
\hline Germany & $\begin{array}{c}-0.094 \\
(-1.31)\end{array}$ & $\begin{array}{c}0.023 \\
(0.95)\end{array}$ & $\begin{array}{c}0.021 \\
(1.26)\end{array}$ & $\begin{array}{c}15.0 \\
(1.32)\end{array}$ & $\begin{array}{c}-13.6 * * \\
(-3.53)\end{array}$ & $\begin{array}{c}-0.1 \\
(-0.58)\end{array}$ & $\begin{array}{c}-1.1 \\
(-1.75)\end{array}$ & $\begin{array}{c}0.1 \\
(0.14)\end{array}$ & $\begin{array}{r}0.010 \\
(0.09)\end{array}$ \\
\hline Austria & $\begin{array}{c}-0.055 \\
(-1.07)\end{array}$ & $\begin{array}{c}0.011 \\
(0.55)\end{array}$ & $\begin{array}{c}0.023 \\
(1.67)\end{array}$ & $\begin{array}{c}-2.5 \\
(-0.31)\end{array}$ & $\begin{array}{c}1.7 \\
(0.61)\end{array}$ & $\begin{array}{c}-0.3 \\
(-1.76)\end{array}$ & $\begin{array}{c}-0.8 \\
(-1.65)\end{array}$ & $\begin{array}{c}-0.2 \\
(-1.29)\end{array}$ & $\begin{array}{r}0.049 \\
(0.00)\end{array}$ \\
\hline Switzerland & $\begin{array}{c}-0.006 \\
(-0.09)\end{array}$ & $\begin{array}{c}0.002 \\
(0.09)\end{array}$ & $\begin{array}{r}0.015 \\
(1.09)\end{array}$ & $\begin{array}{c}11.4 \\
(1.42)\end{array}$ & $\begin{array}{l}-9.6 * * \\
(-3.09)\end{array}$ & $\begin{array}{c}-0.4^{*} \\
(-1.98)\end{array}$ & $\begin{array}{c}-0.6 \\
(-1.10)\end{array}$ & $\begin{array}{c}-0.3 \\
(-1.07)\end{array}$ & $\begin{array}{r}0.010 \\
(0.00)\end{array}$ \\
\hline France & $\begin{array}{c}-0.027 \\
(-0.41)\end{array}$ & $\begin{array}{c}-0.006 \\
(-0.25)\end{array}$ & $\begin{array}{c}0.024 \\
(1.40)\end{array}$ & $\begin{array}{c}3.1 \\
(0.31)\end{array}$ & $\begin{array}{c}-12.8 * * \\
(-3.78)\end{array}$ & $\begin{array}{c}-0.6^{*} \\
(-2.58)\end{array}$ & $\begin{array}{c}-1.4^{*} \\
(-2.55)\end{array}$ & $\begin{array}{c}0.0 \\
(-0.23)\end{array}$ & $\begin{array}{c}0.011 \\
(0.01)\end{array}$ \\
\hline Canada & $\begin{array}{l}-0.100 \\
(-1.64)\end{array}$ & $\begin{array}{l}0.057 * \\
(2.17)\end{array}$ & $\begin{array}{l}0.043^{*} \\
(2.53)\end{array}$ & $\begin{array}{c}-1.4 \\
(-0.17)\end{array}$ & $\begin{array}{l}-9.0 * * \\
(-2.99)\end{array}$ & $\begin{array}{c}0.1 \\
(0.46)\end{array}$ & $\begin{array}{c}-0.4 \\
(-0.76)\end{array}$ & $\begin{array}{c}-0.1 \\
(-1.45)\end{array}$ & $\begin{array}{r}0.010 \\
(0.01)\end{array}$ \\
\hline Italy & $\begin{array}{c}-0.052 \\
(-0.72)\end{array}$ & $\begin{array}{c}0.009 \\
(0.27)\end{array}$ & $\begin{array}{l}0.064 * * \\
(2.90)\end{array}$ & $\begin{array}{c}-9.9 \\
(-1.04)\end{array}$ & $\begin{array}{c}-13.9 * * \\
(-3.48)\end{array}$ & $\begin{array}{c}-0.5 \\
(-1.67)\end{array}$ & $\begin{array}{c}0.1 \\
(0.20)\end{array}$ & $\begin{array}{c}0.3 \\
(1.11)\end{array}$ & $\begin{array}{c}0.021 \\
(0.00)\end{array}$ \\
\hline U.S. - DJIA & $\begin{array}{c}-0.039 \\
(-1.02)\end{array}$ & $\begin{array}{r}0.030 \\
(1.67)\end{array}$ & $\begin{array}{c}0.017 \\
(1.43)\end{array}$ & $\begin{array}{c}4.7 \\
(0.81)\end{array}$ & $\begin{array}{c}-10.5 * * \\
(-4.94)\end{array}$ & $\begin{array}{c}0.0 \\
(-0.00)\end{array}$ & $\begin{array}{c}-0.7^{*} \\
(-2.49)\end{array}$ & $\begin{array}{c}-0.3 \\
(-1.73)\end{array}$ & $\begin{array}{r}0.010 \\
(0.87)\end{array}$ \\
\hline U.S. - S\&P500 & $\begin{array}{r}-0.040 \\
(-1.02)\end{array}$ & $\begin{array}{c}0.029 \\
(1.55)\end{array}$ & $\begin{array}{c}0.015 \\
(1.27)\end{array}$ & $\begin{array}{c}-0.2 \\
(-0.03)\end{array}$ & $\begin{array}{c}-14.9 * * \\
(-6.98)\end{array}$ & $\begin{array}{c}-0.1 \\
(-0.57)\end{array}$ & $\begin{array}{l}-0.8 * * \\
(-2.63)\end{array}$ & $\begin{array}{c}-0.1 \\
(-0.56)\end{array}$ & $\begin{array}{r}0.010 \\
(0.34)\end{array}$ \\
\hline U.S. - ewAMEX & $\begin{array}{c}-0.058 \\
(-1.72)\end{array}$ & $\begin{array}{c}0.013 \\
(0.80)\end{array}$ & $\begin{array}{l}0.047^{* *} \\
(4.08)\end{array}$ & $\begin{array}{l}43.8^{* * *} \\
(6.11)\end{array}$ & $\begin{array}{l}-32.7 * * \\
(-16.28)\end{array}$ & $\begin{array}{c}-0.1 \\
(-0.63)\end{array}$ & $\begin{array}{l}-0.8 * * \\
(-2.82)\end{array}$ & $\begin{array}{c}-0.1 \\
(-0.82)\end{array}$ & $\begin{array}{r}0.177 \\
(0.00)\end{array}$ \\
\hline U.S. - ewNASD & $\begin{array}{r}-0.060 \\
(-1.40)\end{array}$ & $\begin{array}{c}0.015 \\
(0.68)\end{array}$ & $\begin{array}{l}0.053^{* *} \\
(3.91)\end{array}$ & $\begin{array}{l}24.7 * * \\
(3.67)\end{array}$ & $\begin{array}{l}-30.8 * * \\
(-13.71)\end{array}$ & $\begin{array}{c}-0.1 \\
(-0.47)\end{array}$ & $\begin{array}{c}-0.7^{*} \\
(-2.16)\end{array}$ & $\begin{array}{c}0.0 \\
(-0.18)\end{array}$ & $\begin{array}{r}0.104 \\
(0.00)\end{array}$ \\
\hline U.S. - ewNYSE & $\begin{array}{r}-0.067 \\
(-1.94)\end{array}$ & $\begin{array}{r}0.033 \\
(1.92)\end{array}$ & $\begin{array}{l}0.027^{* *} \\
(2.66)\end{array}$ & $\begin{array}{l}19.4 * * \\
(3.54)\end{array}$ & $\begin{array}{l}-22.9 * * \\
(-11.97)\end{array}$ & $\begin{array}{c}-0.1 \\
(-1.08)\end{array}$ & $\begin{array}{l}-0.8^{* *} \\
(-3.18)\end{array}$ & $\begin{array}{c}0.0 \\
(-0.19)\end{array}$ & $\begin{array}{r}0.050 \\
(0.00)\end{array}$ \\
\hline
\end{tabular}


Patrick J. Kelly, Felix Meschke, Sentiment and stock returns: The SAD anomaly revisited, Journal of Banking \& Finance, June 2010, Volume 34.6:1308-1326. Publisher's official version: http://dx.doi.org/10.1016/j.jbankfin.2009.11.027. Open Access version: http://kuscholarworks.ku.edu/dspace/.

\begin{tabular}{|c|c|c|c|c|c|c|c|c|c|}
\hline Country & Fall & $\begin{array}{l}\text { fall } \\
\text { SAD }\end{array}$ & $\begin{array}{l}\text { win } \\
\text { SAD }\end{array}$ & Tax & Monday & Temp & Cloud & Precip. & RSQ \\
\hline U.S. - vwAMEX & $\begin{array}{l}-0.066 \\
(-1.62)\end{array}$ & $\begin{array}{c}0.030 \\
(1.52)\end{array}$ & $\begin{array}{l}0.041^{* *} \\
(3.01)\end{array}$ & $\begin{array}{c}12.1 \\
(1.78)\end{array}$ & $\begin{array}{l}-28.4^{* *} \\
(-12.11)\end{array}$ & $\begin{array}{c}-0.1 \\
(-0.45)\end{array}$ & $\begin{array}{c}-0.8^{*} \\
(-2.31)\end{array}$ & $\begin{array}{c}0.0 \\
(-0.10)\end{array}$ & $\begin{array}{r}0.073 \\
(0.00)\end{array}$ \\
\hline U.S. - vwNASD & $\begin{array}{l}-0.080 \\
(-1.21)\end{array}$ & $\begin{array}{c}0.050 \\
(1.51)\end{array}$ & $\begin{array}{l}0.061^{* *} \\
(2.74)\end{array}$ & $\begin{array}{c}6.2 \\
(0.49)\end{array}$ & $\begin{array}{l}-21.6^{* *} \\
(-6.06)\end{array}$ & $\begin{array}{c}0.2 \\
(0.82)\end{array}$ & $\begin{array}{l}-1.1^{*} \\
(-2.10)\end{array}$ & $\begin{array}{c}0.1 \\
(0.27)\end{array}$ & $\begin{array}{r}0.013 \\
(0.01)\end{array}$ \\
\hline U.S. - vwNYSE & $\begin{array}{l}-0.040 \\
(-1.09)\end{array}$ & $\begin{array}{c}0.028 \\
(1.58)\end{array}$ & $\begin{array}{l}0.015 \\
(1.35)\end{array}$ & $\begin{array}{c}0.2 \\
(0.04)\end{array}$ & $\begin{array}{l}-16.0 * * \\
(-7.95)\end{array}$ & $\begin{array}{c}-0.1 \\
(-0.86)\end{array}$ & $\begin{array}{l}-0.8 * * \\
(-2.75)\end{array}$ & $\begin{array}{c}-0.1 \\
(-0.68)\end{array}$ & $\begin{array}{r}0.017 \\
(0.40)\end{array}$ \\
\hline China & $\begin{array}{c}0.093 \\
(0.38)\end{array}$ & $\begin{array}{c}-0.152 \\
(-1.21)\end{array}$ & $\begin{array}{c}-0.082 \\
(-0.97)\end{array}$ & $\begin{array}{c}39.3 \\
(1.64)\end{array}$ & $\begin{array}{l}-16.1 \\
(-1.26)\end{array}$ & $\begin{array}{c}-0.8 \\
(-1.12)\end{array}$ & $\begin{array}{c}0.9 \\
(0.58)\end{array}$ & $\begin{array}{c}0.2 \\
(0.19)\end{array}$ & $\begin{array}{r}0.005 \\
(0.00)\end{array}$ \\
\hline Spain & $\begin{array}{l}-0.030 \\
(-0.43)\end{array}$ & $\begin{array}{c}0.003 \\
(0.09)\end{array}$ & $\begin{array}{r}0.030 \\
(1.35)\end{array}$ & $\begin{array}{c}4.0 \\
(0.41)\end{array}$ & $\begin{array}{c}7.9 \\
(1.88)\end{array}$ & $\begin{array}{l}-0.5^{*} \\
(-2.08)\end{array}$ & $\begin{array}{c}-0.6 \\
(-1.16)\end{array}$ & $\begin{array}{c}0.2 \\
(1.43)\end{array}$ & $\begin{array}{r}0.016 \\
(0.00)\end{array}$ \\
\hline Greece & $\begin{array}{l}-0.28^{*} \\
(-2.21)\end{array}$ & $\begin{array}{c}0.090 \\
(1.37)\end{array}$ & $\begin{array}{c}0.009 \\
(0.20)\end{array}$ & $\begin{array}{l}40.2^{*} \\
(2.27)\end{array}$ & $\begin{array}{l}-17.1^{*} \\
(-2.32)\end{array}$ & $\begin{array}{c}0.0 \\
(-0.04)\end{array}$ & $\begin{array}{c}1.6 \\
(1.44)\end{array}$ & $\begin{array}{c}1.0 \\
(1.31)\end{array}$ & $\begin{array}{r}0.032 \\
(0.36)\end{array}$ \\
\hline Turkey & $\begin{array}{c}0.128 \\
(0.78)\end{array}$ & $\begin{array}{c}0.035 \\
(0.36)\end{array}$ & $\begin{array}{r}0.112 \\
(1.68)\end{array}$ & $\begin{array}{c}39.8 \\
(1.29)\end{array}$ & $\begin{array}{c}-30.7 * * \\
(-2.98)\end{array}$ & $\begin{array}{c}0.2 \\
(0.34)\end{array}$ & $\begin{array}{c}0.5 \\
(0.27)\end{array}$ & $\begin{array}{c}-1.1 \\
(-1.16)\end{array}$ & $\begin{array}{r}0.012 \\
(0.13)\end{array}$ \\
\hline Korea & $\begin{array}{l}-0.012 \\
(-0.13)\end{array}$ & $\begin{array}{c}0.016 \\
(0.30)\end{array}$ & $\begin{array}{l}-0.007 \\
(-0.15)\end{array}$ & $\begin{array}{c}-5.6 \\
(-0.26)\end{array}$ & $\begin{array}{c}3.1 \\
(0.56)\end{array}$ & $\begin{array}{c}-0.3 \\
(-0.94)\end{array}$ & $\begin{array}{c}-0.3 \\
(-0.47)\end{array}$ & $\begin{array}{c}0.1 \\
(1.55)\end{array}$ & $\begin{array}{r}0.007 \\
(0.00)\end{array}$ \\
\hline Japan & $\begin{array}{l}-0.050 \\
(-0.74)\end{array}$ & $\begin{array}{c}0.008 \\
(0.21)\end{array}$ & $\begin{array}{r}0.007 \\
(0.26)\end{array}$ & $\begin{array}{c}2.7 \\
(0.30)\end{array}$ & $\begin{array}{c}-5.5 \\
(-1.57)\end{array}$ & $\begin{array}{c}-0.2 \\
(-1.08)\end{array}$ & $\begin{array}{l}-1.2^{*} \\
(-2.23)\end{array}$ & $\begin{array}{c}-0.2 \\
(-1.02)\end{array}$ & $\begin{array}{r}0.004 \\
(0.01)\end{array}$ \\
\hline Jordan & $\begin{array}{c}0.034 \\
(0.41)\end{array}$ & $\begin{array}{c}0.003 \\
(0.05)\end{array}$ & $\begin{array}{r}-0.027 \\
(-0.53)\end{array}$ & $\begin{array}{l}43.7 * * \\
(3.10)\end{array}$ & $\begin{array}{c}2.6 \\
(0.49)\end{array}$ & $\begin{array}{c}0.1 \\
(0.23)\end{array}$ & $\begin{array}{c}1.3 \\
(1.25)\end{array}$ & $\begin{array}{c}0.1 \\
(0.15)\end{array}$ & $\begin{array}{r}0.021 \\
(0.02)\end{array}$ \\
\hline Mexico & $\begin{array}{l}-0.132 \\
(-1.09)\end{array}$ & $\begin{array}{c}0.088 \\
(0.67)\end{array}$ & $\begin{array}{c}0.131 \\
(1.46)\end{array}$ & $\begin{array}{l}-13.7 \\
(-0.67)\end{array}$ & $\begin{array}{c}0.9 \\
(0.13)\end{array}$ & $\begin{array}{c}-0.3 \\
(-0.28)\end{array}$ & $\begin{array}{c}-0.2 \\
(-0.14)\end{array}$ & $\begin{array}{c}0.9 \\
(0.81)\end{array}$ & $\begin{array}{r}0.032 \\
(0.00)\end{array}$ \\
\hline Taiwan & $\begin{array}{l}-0.177 \\
(-1.42)\end{array}$ & $\begin{array}{c}0.085 \\
(0.63)\end{array}$ & $\begin{array}{c}0.164 \\
(1.58)\end{array}$ & $\begin{array}{c}11.4 \\
(0.59)\end{array}$ & $\begin{array}{c}9.6 \\
(1.21)\end{array}$ & $\begin{array}{c}-0.6 \\
(-0.87)\end{array}$ & $\begin{array}{c}-2.0 \\
(-1.47)\end{array}$ & $\begin{array}{c}0.0 \\
(0.20)\end{array}$ & $\begin{array}{r}0.011 \\
(0.13)\end{array}$ \\
\hline Hong Kong & $\begin{array}{c}-0.024 \\
(-0.23)\end{array}$ & $\begin{array}{c}0.044 \\
(0.38)\end{array}$ & $\begin{array}{c}0.267 * * \\
(3.16)\end{array}$ & $\begin{array}{c}-3.6 \\
(-0.28)\end{array}$ & $\begin{array}{l}-15.8^{*} \\
(-2.37)\end{array}$ & $\begin{array}{c}0.3 \\
(0.51)\end{array}$ & $\begin{array}{c}-0.1 \\
(-0.12)\end{array}$ & $\begin{array}{c}-0.1 \\
(-0.88)\end{array}$ & $\begin{array}{r}0.009 \\
(0.00)\end{array}$ \\
\hline India & $\begin{array}{l}-0.129 \\
(-1.08)\end{array}$ & $\begin{array}{r}0.217 \\
(1.44)\end{array}$ & $\begin{array}{l}0.271^{*} \\
(2.13)\end{array}$ & $\begin{array}{c}25.8 \\
(1.20)\end{array}$ & $\begin{array}{c}6.7 \\
(0.86)\end{array}$ & $\begin{array}{c}0.6 \\
(0.41)\end{array}$ & $\begin{array}{c}1.9 \\
(1.34)\end{array}$ & $\begin{array}{c}0.1 \\
(0.58)\end{array}$ & $\begin{array}{r}0.017 \\
(0.39)\end{array}$ \\
\hline Thailand & $\begin{array}{r}0.042 \\
(0.57)\end{array}$ & $\begin{array}{c}-0.105 \\
(-0.78)\end{array}$ & $\begin{array}{c}0.153 \\
(1.31)\end{array}$ & $\begin{array}{c}15.7 \\
(1.05)\end{array}$ & $\begin{array}{c}-30.2 * * \\
(-6.16)\end{array}$ & $\begin{array}{c}-1.0 \\
(-0.86)\end{array}$ & $\begin{array}{c}1.0 \\
(0.73)\end{array}$ & $\begin{array}{c}-0.2 \\
(-1.22)\end{array}$ & $\begin{array}{c}0.035 \\
(0.36)\end{array}$ \\
\hline Philippines & $\begin{array}{r}0.017 \\
(0.15)\end{array}$ & $\begin{array}{c}-0.009 \\
(-0.04)\end{array}$ & $\begin{array}{c}0.318 \\
(1.60)\end{array}$ & $\begin{array}{c}2.2 \\
(0.10)\end{array}$ & $\begin{array}{l}-14.9 * \\
(-2.07)\end{array}$ & $\begin{array}{c}-1.3 \\
(-0.72)\end{array}$ & $\begin{array}{c}-3.2 \\
(-1.48)\end{array}$ & $\begin{array}{c}0.4 \\
(0.95)\end{array}$ & $\begin{array}{c}0.033 \\
(0.07)\end{array}$ \\
\hline Sri Lanka & $\begin{array}{c}-0.008 \\
(-0.14)\end{array}$ & $\begin{array}{c}0.116 \\
(0.42)\end{array}$ & $\begin{array}{c}0.236 \\
(0.72)\end{array}$ & $\begin{array}{c}4.2 \\
(0.30)\end{array}$ & $\begin{array}{c}-0.6 \\
(-0.14)\end{array}$ & $\begin{array}{c}-0.9 \\
(-1.11)\end{array}$ & $\begin{array}{c}-2.1^{*} \\
(-2.26)\end{array}$ & $\begin{array}{c}0.3 \\
(1.25)\end{array}$ & $\begin{array}{r}0.181 \\
(0.90)\end{array}$ \\
\hline Malaysia & $\begin{array}{c}0.029 \\
(0.42)\end{array}$ & $\begin{array}{r}0.550 \\
(0.59)\end{array}$ & $\begin{array}{c}-0.013 \\
(-0.02)\end{array}$ & $\begin{array}{c}2.7 \\
(0.23)\end{array}$ & $\begin{array}{c}-22.0 * * \\
(-4.59)\end{array}$ & $\begin{array}{c}1.6 \\
(0.82)\end{array}$ & $\begin{array}{c}-6.1 \\
(-1.16)\end{array}$ & $\begin{array}{c}-0.4 \\
(-1.61)\end{array}$ & $\begin{array}{r}0.018 \\
(0.11)\end{array}$ \\
\hline Singapore & $\begin{array}{l}-0.079 \\
(-0.51)\end{array}$ & $\begin{array}{c}-0.487 \\
(-0.28)\end{array}$ & $\begin{array}{c}-0.554 \\
(-1.44)\end{array}$ & $\begin{array}{l}26.0 * \\
(2.50)\end{array}$ & $\begin{array}{c}-16.9 * * \\
(-4.02)\end{array}$ & $\begin{array}{c}-0.8 \\
(-0.70)\end{array}$ & $\begin{array}{c}-1.9 \\
(-0.98)\end{array}$ & $\begin{array}{c}-0.2 \\
(-1.44)\end{array}$ & $\begin{array}{r}0.015 \\
(0.01)\end{array}$ \\
\hline Indonesia & $\begin{array}{l}-0.037 \\
(-0.28)\end{array}$ & $\begin{array}{r}0.090 \\
(0.23)\end{array}$ & $\begin{array}{l}-0.305^{*} \\
(-2.09)\end{array}$ & $\begin{array}{c}1.8 \\
(0.11)\end{array}$ & $\begin{array}{c}-9.9 \\
(-1.75)\end{array}$ & $\begin{array}{c}-0.8 \\
(-0.97)\end{array}$ & $\begin{array}{c}0.0 \\
(0.01)\end{array}$ & $\begin{array}{l}-0.4^{*} \\
(-2.56)\end{array}$ & $\begin{array}{r}0.090 \\
(0.00)\end{array}$ \\
\hline South Africa & $\begin{array}{l}-0.078 \\
(-1.13)\end{array}$ & $\begin{array}{c}0.113 \\
(1.85)\end{array}$ & $\begin{array}{c}0.080 \\
(1.77)\end{array}$ & $\begin{array}{c}-4.6 \\
(-0.46)\end{array}$ & $\begin{array}{c}-10.5^{* *} \\
(-2.68)\end{array}$ & $\begin{array}{l}1.2^{*} \\
(2.26)\end{array}$ & $\begin{array}{c}0.8 \\
(0.98)\end{array}$ & $\begin{array}{c}-0.1 \\
(-0.75)\end{array}$ & $\begin{array}{r}0.015 \\
(0.07)\end{array}$ \\
\hline $\begin{array}{l}\text { Australia } \\
\text { All Ordinaries }\end{array}$ & $\begin{array}{l}0.120^{*} \\
(2.35)\end{array}$ & $\begin{array}{r}-0.047 \\
(-1.54)\end{array}$ & $\begin{array}{l}0.033 \\
(1.35)\end{array}$ & $\begin{array}{c}7.4 \\
(1.04)\end{array}$ & $\begin{array}{c}0.1 \\
(0.04)\end{array}$ & $\begin{array}{c}0.5 \\
(1.23)\end{array}$ & $\begin{array}{l}-1.1^{*} \\
(-2.10)\end{array}$ & $\begin{array}{c}-0.2 \\
(-1.12)\end{array}$ & $\begin{array}{r}0.010 \\
(0.00)\end{array}$ \\
\hline Australia & 0.098 & -0.041 & 0.028 & 9.7 & -3.0 & 0.8 & -0.8 & -0.3 & 0.016 \\
\hline Total Market & (1.90) & $(-1.29)$ & (1.12) & (1.43) & $(-0.94)$ & (1.83) & $(-1.50)$ & $(-1.73)$ & $(0.00)$ \\
\hline $\begin{array}{l}\text { New Zealand } \\
\text { Canital } 40\end{array}$ & $\begin{array}{r}-0.015 \\
(-0.14)\end{array}$ & 0.000 & $\begin{array}{r}0.021 \\
(059)\end{array}$ & 16.5 & $-12.9^{*}$ & $\begin{array}{c}0.4 \\
(0.34)\end{array}$ & $\begin{array}{c}-0.3 \\
(-0.22)\end{array}$ & $\begin{array}{c}0.0 \\
(0.07)\end{array}$ & $\begin{array}{r}0.004 \\
(0.39)\end{array}$ \\
\hline $\begin{array}{l}\text { New Zealand } \\
\text { FTSE }\end{array}$ & $\begin{array}{r}(-0.14) \\
-0.018 \\
(-0.19)\end{array}$ & $\begin{array}{r}-0.013 \\
(-0.26)\end{array}$ & $\begin{array}{r}(0.09) \\
0.009 \\
(0.28)\end{array}$ & $\begin{array}{l}29.6^{*} \\
(2.19)\end{array}$ & $\begin{array}{c}-9.7^{*} \\
(-2.16)\end{array}$ & $\begin{array}{c}0.2 \\
(0.18)\end{array}$ & $\begin{array}{c}0.1 \\
(0.13)\end{array}$ & $\begin{array}{c}0.0 \\
(0.25)\end{array}$ & $\begin{array}{r}0.004 \\
(0.22)\end{array}$ \\
\hline
\end{tabular}

* Significant at the two-sided 5 percent level

** Significant at the two-sided 1 percent level 
Patrick J. Kelly, Felix Meschke, Sentiment and stock returns: The SAD anomaly revisited, Journal of Banking \& Finance, June 2010, Volume 34.6:1308-1326.

Publisher's official version: http://dx.doi.org/10.1016/j.jbankfin.2009.11.027. Open Access version: http://kuscholarworks.ku.edu/dspace/.

Table 6

Daily returns regression on the fall dummy, monthly SAD measures, and weather controls. The regression model in this table is identical to the model in Table 3 , except that the SAD variable is multiplied by dummies for periods one through six, where period one begins Sept. 21 and ends Oct. 20 ; the period six begins Feb. 21 and ends Mar. 20. For southern hemisphere countries period one begins Mar. 21 and ends Apr. 20; the period six begins Aug. 21 and ends Sept. 20. The last column reports the unadjusted R-squared on top and the p-value from a Ljung-Box (1978) chi-square test for autocorrelation up to ten lags. The intercept and coefficients are lagged returns (included to control for autocorrelation) are not reported to conserve space. t-stats control for heteroskedasticity following MacKinnon and White (1985).

\begin{tabular}{|c|c|c|c|c|c|c|c|c|c|c|c|c|c|}
\hline Country & Fall & $\begin{array}{c}\text { Oct } \\
\text { SAD }\end{array}$ & $\begin{array}{l}\text { Nov } \\
\text { SAD }\end{array}$ & $\begin{array}{c}\text { Dec } \\
\text { SAD }\end{array}$ & $\begin{array}{c}\text { Jan } \\
\text { SAD }\end{array}$ & $\begin{array}{c}\text { Feb } \\
\text { SAD }\end{array}$ & $\begin{array}{l}\text { Mar } \\
\text { SAD }\end{array}$ & Tax & Monday & Temp & Cloud & Precip & RSQ \\
\hline \multirow[t]{2}{*}{ Finland } & -0.083 & 0.093 & 0.019 & -0.003 & 0.007 & -0.009 & -0.013 & 8.5 & -1.0 & $-0.8^{*}$ & -0.1 & -0.7 & 0.003 \\
\hline & $(-0.43)$ & $(0.75)$ & $(0.48)$ & $(-0.10)$ & $(0.48)$ & $(-0.43)$ & $(-0.26)$ & $(0.35)$ & $(-0.17)$ & $(-2.05)$ & $(-0.06)$ & $(-1.02)$ & $(0.02)$ \\
\hline \multirow[t]{2}{*}{ Iceland } & 0.037 & -0.188 & -0.018 & -0.018 & 0.015 & 0.018 & 0.009 & -12.7 & -7.7 & 0.6 & -0.1 & 0.5 & 0.008 \\
\hline & $(0.20)$ & $(-0.85)$ & $(-0.52)$ & $(-0.66)$ & (1.88) & (1.45) & $(0.27)$ & $(-1.07)$ & $(-1.86)$ & (1.35) & $(-0.08)$ & (0.89) & (0.01) \\
\hline \multirow[t]{2}{*}{ Norway } & -0.211 & 0.065 & 0.011 & 0.023 & 0.017 & -0.014 & -0.029 & 27.6 & -6.0 & -0.3 & $-1.5^{*}$ & -0.3 & 0.010 \\
\hline & $(-1.57)$ & $(0.66)$ & $(0.36)$ & (1.05) & (1.26) & $(-0.80)$ & $(-0.73)$ & (1.95) & $(-1.31)$ & $(-1.08)$ & $(-2.00)$ & $(-0.84)$ & $(0.02)$ \\
\hline Sweden & -0.164 & 0.117 & 0.051 & 0.027 & 0.019 & 0.029 & 0.077 & 22.6 & -8.2 & -0.1 & $-1.5^{*}$ & 0.0 & 0.024 \\
\hline$O M X$ & $(-1.28)$ & (1.28) & (1.43) & (1.10) & (1.30) & (1.72) & (1.86) & (1.56) & $(-1.84)$ & $(-0.54)$ & $(-2.02)$ & $(-0.07)$ & $(0.11)$ \\
\hline Sweden & -0.208 & 0.136 & 0.054 & 0.033 & 0.018 & 0.022 & 0.077 & 22.9 & -9.9 & -0.3 & -1.7 & -0.4 & 0.027 \\
\hline Veckans Affärer & $(-1.42)$ & $(1.27)$ & $(1.32)$ & (1.18) & $(1.05)$ & (1.14) & (1.64) & (1.35) & $(-1.89)$ & $(-1.02)$ & $(-1.96)$ & $(-0.54)$ & $(0.00)$ \\
\hline \multirow[t]{2}{*}{ Denmark } & -0.140 & 0.153 & 0.028 & 0.016 & $0.040 *$ & 0.002 & -0.075 & -12.6 & -3.9 & -0.4 & -0.6 & -1.0 & 0.010 \\
\hline & $(-1.03)$ & $(1.42)$ & $(0.66)$ & $(0.53)$ & $(2.39)$ & $(0.12)$ & $(-1.48)$ & $(-0.97)$ & $(-0.85)$ & $(-1.06)$ & $(-0.76)$ & $(-1.30)$ & $(0.00)$ \\
\hline \multirow[t]{2}{*}{ Ireland } & -0.022 & -0.010 & -0.003 & 0.007 & $0.054 * *$ & 0.019 & $0.082 *$ & 7.2 & -1.5 & 0.0 & 0.2 & 0.0 & 0.023 \\
\hline & $(-0.23)$ & $(-0.11)$ & $(-0.10)$ & $(0.27)$ & $(4.54)$ & $(0.97)$ & $(2.00)$ & (1.10) & $(-0.45)$ & $(0.11)$ & $(0.26)$ & $(-0.06)$ & $(0.00)$ \\
\hline \multirow[t]{2}{*}{ Netherlands } & -0.097 & 0.033 & 0.024 & 0.015 & 0.011 & -0.002 & -0.030 & 9.6 & -7.1 & $-0.8 * *$ & $-1.7 * *$ & 0.0 & 0.004 \\
\hline & $(-0.91)$ & $(0.31)$ & $(0.60)$ & $(0.55)$ & $(0.74)$ & $(-0.08)$ & $(-0.67)$ & $(0.91)$ & $(-1.90)$ & $(-2.79)$ & $(-2.75)$ & $(0.12)$ & $(0.00)$ \\
\hline \multirow[t]{2}{*}{ U.K. FTSE 100} & 0.063 & -0.080 & -0.021 & -0.011 & 0.016 & 0.012 & 0.012 & 12.4 & -7.5 & -0.6 & -0.9 & 0.0 & 0.005 \\
\hline & $(0.57)$ & $(-0.60)$ & $(-0.50)$ & $(-0.36)$ & $(1.12)$ & $(0.54)$ & $(0.25)$ & (1.51) & $(-1.89)$ & $(-1.67)$ & $(-1.14)$ & $(-0.10)$ & $(0.00)$ \\
\hline \multirow[t]{2}{*}{ U.K. - Total } & -0.040 & 0.015 & 0.004 & 0.010 & $0.024 *$ & 0.025 & 0.035 & 6.9 & $-14.2 * *$ & $-0.5^{*}$ & -1.1 & -0.2 & 0.011 \\
\hline & $(-0.46)$ & $(0.16)$ & $(0.12)$ & $(0.41)$ & $(2.04)$ & (1.21) & $(0.82)$ & $(1.02)$ & $(-4.50)$ & $(-2.00)$ & $(-1.79)$ & $(-0.56)$ & $(0.00)$ \\
\hline \multirow[t]{2}{*}{ Belgium } & -0.055 & -0.017 & 0.011 & 0.003 & 0.019 & 0.008 & -0.049 & -0.2 & -4.0 & $-0.7 * *$ & $-1.3^{* *}$ & -0.1 & 0.016 \\
\hline & $(-0.68)$ & $(-0.20)$ & $(0.34)$ & $(0.12)$ & $(1.44)$ & $(0.50)$ & $(-1.16)$ & $(-0.02)$ & $(-1.38)$ & $(-3.26)$ & $(-2.66)$ & $(-0.27)$ & $(0.00)$ \\
\hline \multirow[t]{2}{*}{ Germany } & -0.194 & 0.152 & 0.059 & 0.044 & 0.026 & 0.013 & 0.036 & 13.0 & $-13.6^{* *}$ & -0.1 & -1.2 & 0.1 & 0.010 \\
\hline & $(-1.91)$ & (1.38) & (1.45) & (1.52) & (1.33) & $(0.62)$ & $(0.71)$ & (1.05) & $(-3.52)$ & $(-0.58)$ & $(-1.79)$ & (0.15) & $(0.11)$ \\
\hline \multirow[t]{2}{*}{ Austria } & -0.056 & 0.019 & 0.008 & 0.013 & 0.021 & 0.027 & 0.025 & -1.6 & 1.7 & -0.3 & -0.8 & -0.2 & 0.049 \\
\hline & $(-0.76)$ & $(0.21)$ & $(0.22)$ & $(0.54)$ & (1.33) & (1.48) & $(0.57)$ & $(-0.18)$ & $(0.61)$ & $(-1.57)$ & $(-1.63)$ & $(-1.29)$ & $(0.00)$ \\
\hline \multirow[t]{2}{*}{ Switzerland } & -0.091 & 0.109 & 0.035 & 0.014 & 0.023 & -0.006 & -0.066 & 6.1 & $-9.6 * *$ & $-0.5^{* *}$ & -0.6 & -0.3 & 0.011 \\
\hline & $(-1.05)$ & $(0.98)$ & $(0.90)$ & $(0.52)$ & (1.47) & $(-0.32)$ & $(-1.47)$ & $(0.70)$ & $(-3.07)$ & $(-2.66)$ & $(-1.26)$ & $(-1.12)$ & $(0.01)$ \\
\hline \multirow[t]{2}{*}{ France } & -0.046 & 0.009 & 0.008 & -0.006 & 0.033 & 0.005 & 0.025 & -0.7 & $-12.8 * *$ & $-0.7 * *$ & $-1.5 *$ & 0.0 & 0.011 \\
\hline & $(-0.51)$ & $(0.08)$ & $(0.18)$ & $(-0.21)$ & $(1.82)$ & $(0.22)$ & $(0.43)$ & $(-0.07)$ & $(-3.77)$ & $(-2.60)$ & $(-2.57)$ & $(-0.23)$ & $(0.01)$ \\
\hline
\end{tabular}


Patrick J. Kelly, Felix Meschke, Sentiment and stock returns: The SAD anomaly revisited, Journal of Banking \& Finance, June 2010, Volume 34.6:1308-1326. Publisher's official version: http://dx.doi.org/10.1016/j.jbankfin.2009.11.027. Open Access version: http://kuscholarworks.ku.edu/dspace/.

\begin{tabular}{|c|c|c|c|c|c|c|c|c|c|c|c|c|c|}
\hline Country & Fall & $\begin{array}{c}\text { Oct } \\
\text { SAD }\end{array}$ & $\begin{array}{l}\text { Nov } \\
\text { SAD }\end{array}$ & $\begin{array}{l}\text { Dec } \\
\text { SAD }\end{array}$ & $\begin{array}{l}\text { Jan } \\
\text { SAD }\end{array}$ & $\begin{array}{l}\text { Feb } \\
\text { SAD }\end{array}$ & $\begin{array}{l}\text { Mar } \\
\text { SAD }\end{array}$ & Tax & Monday & Temp & Cloud & Precip & RSQ \\
\hline \multirow[t]{2}{*}{ Canada } & -0.096 & 0.054 & 0.047 & 0.057 & $0.053^{* *}$ & 0.026 & 0.042 & -4.8 & $-8.9 * *$ & 0.0 & -0.4 & -0.1 & 0.010 \\
\hline & $(-1.17)$ & $(0.40)$ & (1.09) & (1.79) & $(2.84)$ & (1.09) & $(0.78)$ & $(-0.56)$ & $(-2.96)$ & $(0.25)$ & $(-0.75)$ & $(-1.46)$ & $(0.02)$ \\
\hline \multirow[t]{2}{*}{ Italy } & -0.069 & 0.005 & 0.023 & -0.001 & $0.091^{* *}$ & 0.012 & -0.028 & $-20.7^{*}$ & $-13.9 * *$ & $-0.6^{*}$ & 0.1 & 0.3 & 0.022 \\
\hline & $(-0.68)$ & $(0.03)$ & $(0.42)$ & $(-0.04)$ & (3.71) & $(0.38)$ & $(-0.38)$ & $(-2.01)$ & $(-3.46)$ & $(-2.21)$ & $(0.21)$ & $(1.10)$ & $(0.00)$ \\
\hline \multirow[t]{2}{*}{ U.S. - DJIA } & -0.047 & 0.044 & 0.036 & 0.032 & 0.022 & 0.009 & 0.032 & 3.5 & $-10.5^{* *}$ & 0.0 & $-0.7 *$ & -0.3 & 0.010 \\
\hline & $(-0.85)$ & $(0.45)$ & (1.17) & (1.39) & (1.67) & $(0.55)$ & $(0.72)$ & $(0.57)$ & $(-4.93)$ & $(-0.02)$ & $(-2.51)$ & $(-1.73)$ & $(0.86)$ \\
\hline \multirow[t]{2}{*}{ U.S. - S\&P500 } & -0.046 & 0.039 & 0.029 & 0.030 & 0.022 & -0.001 & 0.010 & -2.7 & $-14.9 * *$ & -0.1 & $-0.8 * *$ & -0.1 & 0.010 \\
\hline & $(-0.83)$ & $(0.42)$ & $(0.93)$ & (1.30) & $(1.76)$ & $(-0.03)$ & $(0.23)$ & $(-0.44)$ & $(-6.98)$ & $(-0.75)$ & $(-2.62)$ & $(-0.57)$ & $(0.34)$ \\
\hline \multirow[t]{2}{*}{ U.S. - ewAMEX } & -0.003 & -0.101 & -0.015 & -0.008 & $0.051 * *$ & $0.034 *$ & 0.008 & $41.7 * *$ & $-32.7 * *$ & -0.1 & $-0.8 * *$ & -0.1 & 0.177 \\
\hline & $(-0.05)$ & $(-1.29)$ & $(-0.59)$ & $(-0.41)$ & $(4.03)$ & $(2.28)$ & $(0.20)$ & (5.68) & $(-16.27)$ & $(-1.01)$ & $(-2.84)$ & $(-0.84)$ & $(0.00)$ \\
\hline \multirow[t]{2}{*}{ U.S. - ewNASD } & -0.060 & -0.013 & 0.023 & 0.004 & $0.061^{* *}$ & 0.028 & -0.002 & $20.7 * *$ & $-30.8 * *$ & -0.1 & $-0.7^{*}$ & 0.0 & 0.105 \\
\hline & $(-1.01)$ & $(-0.13)$ & $(0.68)$ & $(0.14)$ & $(4.16)$ & $(1.57)$ & $(-0.04)$ & (2.97) & $(-13.69)$ & $(-1.06)$ & $(-2.14)$ & $(-0.20)$ & $(0.00)$ \\
\hline \multirow[t]{2}{*}{ U.S. - ewNYSE } & -0.038 & -0.025 & 0.016 & 0.023 & $0.034 * *$ & 0.013 & 0.016 & $17.1^{* *}$ & $-22.9 * *$ & -0.1 & $-0.8 * *$ & 0.0 & 0.050 \\
\hline & $(-0.79)$ & $(-0.33)$ & $(0.59)$ & (1.11) & $(3.04)$ & $(0.93)$ & $(0.43)$ & $(3.00)$ & $(-11.96)$ & $(-1.26)$ & $(-3.19)$ & $(-0.21)$ & $(0.00)$ \\
\hline \multirow[t]{2}{*}{ U.S. - vwAMEX } & -0.017 & -0.069 & 0.002 & 0.012 & $0.051 * *$ & 0.017 & 0.011 & 8.1 & $-28.4 * *$ & -0.1 & $-0.8^{*}$ & 0.0 & 0.074 \\
\hline & $(-0.31)$ & $(-0.75)$ & $(0.07)$ & $(0.48)$ & (3.54) & $(0.89)$ & $(0.24)$ & (1.16) & $(-12.11)$ & $(-0.82)$ & $(-2.32)$ & $(-0.12)$ & $(0.00)$ \\
\hline \multirow[t]{2}{*}{ U.S. - vwNASD } & -0.135 & 0.134 & 0.079 & 0.058 & $0.080 * *$ & 0.017 & 0.028 & -0.9 & $-21.6 * *$ & 0.1 & $-1.0 *$ & 0.1 & 0.013 \\
\hline & $(-1.50)$ & $(0.93)$ & (1.53) & (1.49) & (3.37) & $(0.56)$ & $(0.37)$ & $(-0.07)$ & $(-6.05)$ & $(0.31)$ & $(-2.07)$ & $(0.25)$ & $(0.02)$ \\
\hline \multirow{2}{*}{ U.S. - vwNYSE } & -0.034 & 0.014 & 0.023 & 0.025 & 0.021 & 0.001 & 0.010 & -2.0 & $-16.0^{* *}$ & -0.1 & $-0.7 * *$ & -0.1 & 0.017 \\
\hline & $(-0.66)$ & $(0.16)$ & $(0.80)$ & (1.15) & $(1.82)$ & $(0.06)$ & $(0.25)$ & $(-0.37)$ & $(-7.95)$ & $(-1.01)$ & $(-2.75)$ & $(-0.69)$ & $(0.40)$ \\
\hline \multirow[t]{2}{*}{ China } & -0.100 & 0.137 & -0.001 & -0.122 & -0.120 & -0.021 & -0.220 & 47.4 & -15.9 & -0.9 & 1.0 & 0.2 & 0.006 \\
\hline & $(-0.35)$ & $(0.35)$ & $(-0.01)$ & $(-0.92)$ & $(-1.40)$ & $(-0.17)$ & $(-0.69)$ & (1.91) & $(-1.24)$ & $(-1.16)$ & $(0.62)$ & $(0.18)$ & $(0.00)$ \\
\hline \multirow[t]{2}{*}{ Spain } & -0.089 & 0.109 & 0.043 & 0.017 & 0.042 & 0.013 & 0.047 & 0.8 & 7.9 & $-0.5^{*}$ & -0.6 & 0.2 & 0.016 \\
\hline & $(-0.96)$ & $(0.74)$ & $(0.75)$ & $(0.42)$ & (1.58) & $(0.44)$ & $(0.60)$ & $(0.07)$ & (1.88) & $(-2.07)$ & $(-1.19)$ & (1.45) & $(0.00)$ \\
\hline \multirow[t]{2}{*}{ Greece } & -0.222 & 0.017 & 0.026 & 0.087 & -0.023 & 0.063 & -0.093 & $48.6^{*}$ & $-17.2 *$ & 0.0 & 1.7 & 1.0 & 0.033 \\
\hline & $(-1.29)$ & $(0.06)$ & $(0.24)$ & (1.13) & $(-0.45)$ & (1.08) & $(-0.56)$ & $(2.52)$ & $(-2.33)$ & $(0.06)$ & (1.50) & (1.33) & $(0.40)$ \\
\hline \multirow[t]{2}{*}{ Turkey } & 0.205 & -0.104 & -0.065 & 0.006 & $0.161^{*}$ & -0.019 & -0.099 & 21.5 & $-30.6 * *$ & -0.1 & 0.3 & -1.1 & 0.013 \\
\hline & $(0.94)$ & $(-0.31)$ & $(-0.45)$ & $(0.05)$ & $(2.21)$ & $(-0.19)$ & $(-0.31)$ & $(0.67)$ & $(-2.97)$ & $(-0.19)$ & $(0.17)$ & $(-1.15)$ & (0.13) \\
\hline \multirow[t]{2}{*}{ Korea } & -0.101 & 0.181 & 0.065 & 0.027 & -0.015 & -0.034 & -0.221 & -8.8 & 3.0 & -0.5 & -0.3 & 0.1 & 0.008 \\
\hline & $(-0.87)$ & $(0.93)$ & $(0.82)$ & $(0.44)$ & $(-0.27)$ & $(-0.57)$ & $(-1.67)$ & $(-0.39)$ & (0.55) & $(-1.51)$ & $(-0.41)$ & (1.52) & $(0.00)$ \\
\hline \multirow[t]{2}{*}{ Japan } & -0.032 & -0.006 & -0.041 & 0.006 & 0.004 & -0.010 & -0.127 & 1.1 & -5.5 & -0.4 & $-1.3^{*}$ & -0.2 & 0.004 \\
\hline & $(-0.37)$ & $(-0.04)$ & $(-0.66)$ & $(0.13)$ & $(0.13)$ & $(-0.26)$ & $(-1.23)$ & $(0.12)$ & $(-1.57)$ & $(-1.47)$ & $(-2.33)$ & $(-1.06)$ & $(0.01)$ \\
\hline \multirow[t]{2}{*}{ Jordan } & 0.087 & -0.187 & -0.017 & -0.032 & -0.008 & -0.052 & -0.032 & $39.7 * *$ & 2.5 & 0.1 & 1.3 & 0.1 & 0.022 \\
\hline & $(0.71)$ & $(-0.80)$ & $(-0.16)$ & $(-0.40)$ & $(-0.15)$ & $(-0.72)$ & $(-0.19)$ & (2.67) & $(0.48)$ & $(0.16)$ & (1.29) & $(0.15)$ & $(0.02)$ \\
\hline \multirow[t]{2}{*}{ Mexico } & -0.162 & 0.277 & 0.077 & 0.116 & 0.157 & 0.096 & -0.059 & -17.8 & 0.8 & -0.3 & -0.3 & 0.9 & 0.032 \\
\hline & $(-1.09)$ & $(0.51)$ & $(0.37)$ & $(0.82)$ & $(1.42)$ & $(0.78)$ & $(-0.16)$ & $(-0.80)$ & $(0.12)$ & $(-0.29)$ & $(-0.25)$ & $(0.80)$ & $(0.00)$ \\
\hline
\end{tabular}


Patrick J. Kelly, Felix Meschke, Sentiment and stock returns: The SAD anomaly revisited, Journal of Banking \& Finance, June 2010, Volume 34.6:1308-1326. Publisher's official version: http://dx.doi.org/10.1016/j.jbankfin.2009.11.027. Open Access version: http://kuscholarworks.ku.edu/dspace/.

\begin{tabular}{|c|c|c|c|c|c|c|c|c|c|c|c|c|c|}
\hline Country & Fall & $\begin{array}{l}\text { Oct } \\
\text { SAD }\end{array}$ & $\begin{array}{l}\text { Nov } \\
\text { SAD }\end{array}$ & $\begin{array}{l}\text { Dec } \\
\text { SAD }\end{array}$ & $\begin{array}{c}\text { Jan } \\
\text { SAD }\end{array}$ & $\begin{array}{l}\text { Feb } \\
\text { SAD }\end{array}$ & $\begin{array}{l}\text { Mar } \\
\text { SAD }\end{array}$ & Tax & Monday & Temp & Cloud & Precip & RSQ \\
\hline Taiwan & $\begin{array}{c}-0.068 \\
(-0.43)\end{array}$ & $\begin{array}{c}-0.595 \\
(-1.13)\end{array}$ & $\begin{array}{c}0.026 \\
(0.13)\end{array}$ & $\begin{array}{c}-0.018 \\
(-0.12)\end{array}$ & $\begin{array}{r}0.127 \\
(1.09)\end{array}$ & $\begin{array}{c}0.222 \\
(1.61)\end{array}$ & $\begin{array}{c}-0.085 \\
(-0.22)\end{array}$ & $\begin{array}{c}15.0 \\
(0.72)\end{array}$ & $\begin{array}{c}9.6 \\
(1.21)\end{array}$ & $\begin{array}{c}-0.7 \\
(-0.93)\end{array}$ & $\begin{array}{c}-2.2 \\
(-1.55)\end{array}$ & $\begin{array}{c}0.0 \\
(0.14)\end{array}$ & $\begin{array}{r}0.012 \\
(0.13)\end{array}$ \\
\hline Hong Kong & $\begin{array}{c}-0.067 \\
(-0.51)\end{array}$ & $\begin{array}{c}0.345 \\
(0.76)\end{array}$ & $\begin{array}{c}0.024 \\
(0.14)\end{array}$ & $\begin{array}{c}0.077 \\
(0.59)\end{array}$ & $\begin{array}{l}0.237 * * \\
(2.72)\end{array}$ & $\begin{array}{l}0.291^{*} \\
(2.17)\end{array}$ & $\begin{array}{c}-0.172 \\
(-0.56)\end{array}$ & $\begin{array}{c}-5.2 \\
(-0.40)\end{array}$ & $\begin{array}{l}-15.8^{*} \\
(-2.37)\end{array}$ & $\begin{array}{c}0.1 \\
(0.14)\end{array}$ & $\begin{array}{c}-0.2 \\
(-0.15)\end{array}$ & $\begin{array}{c}-0.1 \\
(-0.94)\end{array}$ & $\begin{array}{c}0.009 \\
(0.00)\end{array}$ \\
\hline India & $\begin{array}{c}-0.019 \\
(-0.14)\end{array}$ & $\begin{array}{c}-0.370 \\
(-0.55)\end{array}$ & $\begin{array}{c}0.008 \\
(0.04)\end{array}$ & $\begin{array}{c}0.212 \\
(1.31)\end{array}$ & $\begin{array}{c}0.254 \\
(1.92)\end{array}$ & $\begin{array}{l}0.485^{* *} \\
(2.61)\end{array}$ & $\begin{array}{c}0.849 \\
(1.24)\end{array}$ & $\begin{array}{c}28.9 \\
(1.34)\end{array}$ & $\begin{array}{c}6.8 \\
(0.87)\end{array}$ & $\begin{array}{c}1.6 \\
(0.98)\end{array}$ & $\begin{array}{c}2.5 \\
(1.79)\end{array}$ & $\begin{array}{c}0.2 \\
(0.70)\end{array}$ & $\begin{array}{c}0.018 \\
(0.39)\end{array}$ \\
\hline Thailand & $\begin{array}{c}0.017 \\
(0.21)\end{array}$ & $\begin{array}{c}0.209 \\
(0.41)\end{array}$ & $\begin{array}{c}-0.114 \\
(-0.59)\end{array}$ & $\begin{array}{c}-0.072 \\
(-0.51)\end{array}$ & $\begin{array}{c}0.222 \\
(1.66)\end{array}$ & $\begin{array}{c}0.094 \\
(0.59)\end{array}$ & $\begin{array}{c}-0.801 \\
(-1.67)\end{array}$ & $\begin{array}{c}9.8 \\
(0.62)\end{array}$ & $\begin{array}{c}-30.1^{* *} \\
(-6.14)\end{array}$ & $\begin{array}{c}-1.0 \\
(-0.82)\end{array}$ & $\begin{array}{c}1.0 \\
(0.68)\end{array}$ & $\begin{array}{c}-0.2 \\
(-1.28)\end{array}$ & $\begin{array}{c}0.036 \\
(0.37)\end{array}$ \\
\hline Philippines & $\begin{array}{c}0.004 \\
(0.04)\end{array}$ & $\begin{array}{c}0.462 \\
(0.43)\end{array}$ & $\begin{array}{c}-0.085 \\
(-0.26)\end{array}$ & $\begin{array}{c}0.030 \\
(0.13)\end{array}$ & $\begin{array}{c}0.402 \\
(1.82)\end{array}$ & $\begin{array}{c}0.199 \\
(0.65)\end{array}$ & $\begin{array}{c}0.032 \\
(0.04)\end{array}$ & $\begin{array}{c}-3.6 \\
(-0.16)\end{array}$ & $\begin{array}{l}-14.9^{*} \\
(-2.07)\end{array}$ & $\begin{array}{c}-1.4 \\
(-0.79)\end{array}$ & $\begin{array}{c}-3.3 \\
(-1.50)\end{array}$ & $\begin{array}{c}0.4 \\
(0.91)\end{array}$ & $\begin{array}{c}0.033 \\
(0.07)\end{array}$ \\
\hline Sri Lanka & $\begin{array}{c}-0.039 \\
(-0.60)\end{array}$ & $\begin{array}{c}-0.250 \\
(-0.24)\end{array}$ & $\begin{array}{c}0.586 \\
(1.21)\end{array}$ & $\begin{array}{c}0.089 \\
(0.29)\end{array}$ & $\begin{array}{c}0.312 \\
(0.69)\end{array}$ & $\begin{array}{l}-0.089 \\
(-0.23)\end{array}$ & $\begin{array}{c}0.589 \\
(0.46)\end{array}$ & $\begin{array}{c}3.5 \\
(0.25)\end{array}$ & $\begin{array}{c}-0.6 \\
(-0.12)\end{array}$ & $\begin{array}{c}-0.9 \\
(-1.12)\end{array}$ & $\begin{array}{c}-2.3^{*} \\
(-2.26)\end{array}$ & $\begin{array}{c}0.2 \\
(1.17)\end{array}$ & $\begin{array}{c}0.182 \\
(0.91)\end{array}$ \\
\hline Malaysia & $\begin{array}{c}0.050 \\
(0.32)\end{array}$ & $\begin{array}{r}0.362 \\
(0.23)\end{array}$ & $\begin{array}{l}1.046 \\
(0.27)\end{array}$ & $\begin{array}{c}-1.753 \\
(-0.18)\end{array}$ & $\begin{array}{l}-10.967^{*} \\
(-2.32)\end{array}$ & $\begin{array}{l}-5.005^{* *} \\
(-3.47)\end{array}$ & $\begin{array}{c}1.033 \\
(1.79)\end{array}$ & $\begin{array}{c}-8.6 \\
(-0.68)\end{array}$ & $\begin{array}{l}-21.8 * * \\
(-4.56)\end{array}$ & $\begin{array}{c}2.6 \\
(1.30)\end{array}$ & $\begin{array}{c}-3.6 \\
(-0.71)\end{array}$ & $\begin{array}{c}-0.3 \\
(-1.29)\end{array}$ & $\begin{array}{c}0.021 \\
(0.09)\end{array}$ \\
\hline Singapore & $\begin{array}{c}-0.613 \\
(-0.88)\end{array}$ & $\begin{array}{c}-5.288 \\
(-0.87)\end{array}$ & $\begin{array}{c}-6.560 \\
(-0.79)\end{array}$ & $\begin{array}{c}-8.673 \\
(-0.88)\end{array}$ & $\begin{array}{c}-1.908 \\
(-1.84)\end{array}$ & $\begin{array}{l}-2.130^{* *} \\
(-2.96)\end{array}$ & $\begin{array}{c}0.509 \\
(1.23)\end{array}$ & $\begin{array}{c}18.4 \\
(1.54)\end{array}$ & $\begin{array}{c}-16.8 * * \\
(-4.00)\end{array}$ & $\begin{array}{c}0.0 \\
(-0.03)\end{array}$ & $\begin{array}{c}-1.6 \\
(-0.83)\end{array}$ & $\begin{array}{c}-0.2 \\
(-1.24)\end{array}$ & $\begin{array}{r}0.017 \\
(0.02)\end{array}$ \\
\hline Indonesia & $\begin{array}{c}0.014 \\
(0.05)\end{array}$ & $\begin{array}{c}-0.225 \\
(-0.16)\end{array}$ & $\begin{array}{c}-0.082 \\
(-0.09)\end{array}$ & $\begin{array}{c}-0.049 \\
(-0.07)\end{array}$ & $\begin{array}{c}-0.168 \\
(-1.15)\end{array}$ & $\begin{array}{l}-0.461^{*} \\
(-2.17)\end{array}$ & $\begin{array}{c}-0.629 \\
(-1.21)\end{array}$ & $\begin{array}{c}1.2 \\
(0.08)\end{array}$ & $\begin{array}{c}-9.9 \\
(-1.74)\end{array}$ & $\begin{array}{c}-0.8 \\
(-0.97)\end{array}$ & $\begin{array}{c}-0.3 \\
(-0.14)\end{array}$ & $\begin{array}{c}-0.4^{*} \\
(-2.56)\end{array}$ & $\begin{array}{c}0.091 \\
(0.00)\end{array}$ \\
\hline South Africa & $\begin{array}{c}-0.22^{*} \\
(-1.99)\end{array}$ & $\begin{array}{c}0.377 \\
(1.82)\end{array}$ & $\begin{array}{l}0.257 * * \\
(2.63)\end{array}$ & $\begin{array}{l}0.163^{*} \\
(2.11)\end{array}$ & $\begin{array}{c}0.077 \\
(1.66)\end{array}$ & $\begin{array}{c}0.067 \\
(1.14)\end{array}$ & $\begin{array}{c}0.011 \\
(0.10)\end{array}$ & $\begin{array}{c}-4.9 \\
(-0.49)\end{array}$ & $\begin{array}{c}-10.5 * * \\
(-2.67)\end{array}$ & $\begin{array}{c}1.1^{*} \\
(1.98)\end{array}$ & $\begin{array}{c}0.6 \\
(0.82)\end{array}$ & $\begin{array}{c}-0.1 \\
(-0.80)\end{array}$ & $\begin{array}{c}0.015 \\
(0.07)\end{array}$ \\
\hline Australia & 0.016 & 0.127 & 0.016 & -0.009 & 0.029 & 0.037 & 0.026 & 8.2 & 0.1 & 0.5 & $-1.1^{*}$ & -0.2 & 0.011 \\
\hline $\begin{array}{l}\text { All Ordinaries } \\
\text { Australia }\end{array}$ & $\begin{array}{r}(0.20) \\
0.001\end{array}$ & $\begin{array}{r}(1.13) \\
0.107\end{array}$ & $\begin{array}{r}(0.32) \\
0.030\end{array}$ & $\begin{array}{r}(-0.23) \\
-0.013\end{array}$ & $\begin{array}{r}(1.16) \\
0.026\end{array}$ & $\begin{array}{r}(1.16) \\
0.027\end{array}$ & $\begin{array}{r}(0.43) \\
0.009\end{array}$ & $\begin{array}{c}(1.11) \\
9.7\end{array}$ & $\begin{array}{l}(0.05) \\
-3.0\end{array}$ & $\begin{array}{c}(1.13) \\
0.7\end{array}$ & $\begin{array}{c}(-2.09) \\
-0.8\end{array}$ & $\begin{array}{c}(-1.17) \\
-0.3\end{array}$ & $\begin{array}{r}(0.00) \\
0.016\end{array}$ \\
\hline Total Market & $(0.01)$ & $(0.94)$ & (0.59) & $(-0.32)$ & $(1.02)$ & $(0.81)$ & $(0.14)$ & (1.36) & $(-0.94)$ & (1.61) & $(-1.55)$ & $(-1.78)$ & $(0.00)$ \\
\hline New Zealand & -0.029 & 0.017 & -0.024 & -0.009 & 0.028 & -0.027 & $-0.229 *$ & 15.2 & $-12.8 *$ & -0.4 & 0.0 & 0.0 & 0.008 \\
\hline Capital 40 & $(-0.19)$ & $(0.08)$ & $(-0.28)$ & $(-0.12)$ & $(0.75)$ & $(-0.56)$ & $(-2.02)$ & $(0.91)$ & $(-2.52)$ & $(-0.30)$ & $(0.02)$ & $(0.09)$ & $(0.33)$ \\
\hline $\begin{array}{l}\text { New Zealand } \\
\text { FTSE }\end{array}$ & $\begin{array}{c}-0.009 \\
(-0.06)\end{array}$ & $\begin{array}{c}-0.055 \\
(-0.31)\end{array}$ & $\begin{array}{c}-0.021 \\
(-0.26)\end{array}$ & $\begin{array}{c}-0.034 \\
(-0.53)\end{array}$ & $\begin{array}{c}0.014 \\
(0.43)\end{array}$ & $\begin{array}{c}-0.031 \\
(-0.73)\end{array}$ & $\begin{array}{c}-0.156 \\
(-1.61)\end{array}$ & $\begin{array}{l}30.5^{*} \\
(2.21)\end{array}$ & $\begin{array}{c}-9.7^{*} \\
(-2.15)\end{array}$ & $\begin{array}{c}-0.3 \\
(-0.37)\end{array}$ & $\begin{array}{c}0.3 \\
(0.25)\end{array}$ & $\begin{array}{c}0.0 \\
(0.21)\end{array}$ & $\begin{array}{r}0.005 \\
(0.19)\end{array}$ \\
\hline
\end{tabular}

* Significant at the two-sided 5 percent level

** Significant at the two-sided 1 percent level 
Table 7

Daily returns regression on the onset/recover measure and weather controls. Table 7 reports coefficients and (tstatistics) from a regression of daily index returns in percent using the return series described in Table 1 on the Kamstra et al. (2007) onset/recovery measure, tax and Monday dummies, and weather variables gathered from hourly weather data from NOAA and averaged over 6am to 4pm (Temperature, Cloud Cover, and Precipitation). Control variables coefficients are multiplied by 100. The last column reports the unadjusted R-squared on top and the p-value from a Ljung-Box (1978) chi-square test for autocorrelation up to ten lags in parentheses. The intercept and coefficients of lagged index returns (included to control for autocorrelation) are not reported to conserve space. t-statistics control for heteroskedasticity following MacKinnon and White (1985).

\begin{tabular}{|c|c|c|c|c|c|c|c|}
\hline Country & $\begin{array}{c}\text { Onset/ } \\
\text { Recovery }\end{array}$ & Tax & Monday & Temp & Cloud & Precip. & RSQ \\
\hline Finland & $\begin{array}{c}0.013 \\
(0.10)\end{array}$ & $\begin{array}{c}15.7 \\
(0.69)\end{array}$ & $\begin{array}{c}-1.1 \\
(-0.18)\end{array}$ & $\begin{array}{c}-0.7^{*} \\
(-2.48)\end{array}$ & $\begin{array}{c}-0.1 \\
(-0.10)\end{array}$ & $\begin{array}{c}-0.7 \\
(-1.03)\end{array}$ & $\begin{array}{r}0.002 \\
(0.02)\end{array}$ \\
\hline Iceland & $\begin{array}{c}-0.275 \\
(-1.59)\end{array}$ & $\begin{array}{c}1.3 \\
(0.12)\end{array}$ & $\begin{array}{c}-8.4^{*} \\
(-2.10)\end{array}$ & $\begin{array}{c}0.8 \\
(1.57)\end{array}$ & $\begin{array}{c}0.1 \\
(0.13)\end{array}$ & $\begin{array}{c}0.4 \\
(0.77)\end{array}$ & $\begin{array}{r}0.009 \\
(0.79)\end{array}$ \\
\hline Norway & $\begin{array}{l}-0.193^{*} \\
(-2.14)\end{array}$ & $\begin{array}{l}45.5^{* *} \\
(3.69)\end{array}$ & $\begin{array}{c}-6.0 \\
(-1.30)\end{array}$ & $\begin{array}{c}0.0 \\
(0.02)\end{array}$ & $\begin{array}{c}-1.5 \\
(-1.96)\end{array}$ & $\begin{array}{c}-0.3 \\
(-0.91)\end{array}$ & $\begin{array}{r}0.009 \\
(0.02)\end{array}$ \\
\hline Sweden & -0.117 & $28.5^{*}$ & -8.1 & -0.3 & -1.3 & 0.0 & 0.023 \\
\hline$O M X$ & $(-1.34)$ & (2.26) & $(-1.82)$ & $(-1.61)$ & $(-1.85)$ & $(-0.07)$ & $(0.11)$ \\
\hline Sweden & -0.153 & $29.8 *$ & -9.9 & -0.4 & -1.6 & -0.4 & 0.026 \\
\hline Veckans Affärer & $(-1.53)$ & (2.02) & $(-1.89)$ & $(-1.67)$ & $(-1.83)$ & $(-0.52)$ & $(0.00)$ \\
\hline Denmark & $\begin{array}{c}-0.009 \\
(-0.10)\end{array}$ & $\begin{array}{c}7.8 \\
(0.69)\end{array}$ & $\begin{array}{c}-3.8 \\
(-0.84)\end{array}$ & $\begin{array}{c}-0.4 \\
(-1.36)\end{array}$ & $\begin{array}{c}-0.7 \\
(-0.81)\end{array}$ & $\begin{array}{c}-1.0 \\
(-1.28)\end{array}$ & $\begin{array}{r}0.006 \\
(0.00)\end{array}$ \\
\hline Ireland & $\begin{array}{l}-0.179 * \\
(-2.53)\end{array}$ & $\begin{array}{c}-0.9 \\
(-0.15)\end{array}$ & $\begin{array}{c}-1.6 \\
(-0.47)\end{array}$ & $\begin{array}{c}-0.2 \\
(-0.75)\end{array}$ & $\begin{array}{c}0.3 \\
(0.39)\end{array}$ & $\begin{array}{c}0.0 \\
(0.04)\end{array}$ & $\begin{array}{r}0.021 \\
(0.00)\end{array}$ \\
\hline Netherlands & $\begin{array}{l}-0.195^{* *} \\
(-2.59)\end{array}$ & $\begin{array}{c}17.2 \\
(1.84)\end{array}$ & $\begin{array}{c}-7.1 \\
(-1.90)\end{array}$ & $\begin{array}{c}-0.5^{*} \\
(-2.16)\end{array}$ & $\begin{array}{l}-1.6^{* *} \\
(-2.62)\end{array}$ & $\begin{array}{c}0.1 \\
(0.18)\end{array}$ & $\begin{array}{r}0.005 \\
(0.00)\end{array}$ \\
\hline U.K. FTSE 100 & $\begin{array}{c}-0.026 \\
(-0.32)\end{array}$ & $\begin{array}{c}10.3 \\
(1.28)\end{array}$ & $\begin{array}{c}-7.5 \\
(-1.88)\end{array}$ & $\begin{array}{l}-0.7 * * \\
(-2.66)\end{array}$ & $\begin{array}{c}-0.8 \\
(-1.12)\end{array}$ & $\begin{array}{c}0.0 \\
(-0.09)\end{array}$ & $\begin{array}{r}0.005 \\
(0.00)\end{array}$ \\
\hline U.K. - Tot. Mkt. & $\begin{array}{l}-0.071 \\
(-1.09)\end{array}$ & $\begin{array}{c}3.3 \\
(0.50)\end{array}$ & $\begin{array}{l}-14.2^{* *} \\
(-4.49)\end{array}$ & $\begin{array}{l}-0.7 * * \\
(-3.45)\end{array}$ & $\begin{array}{c}-1.0 \\
(-1.72)\end{array}$ & $\begin{array}{c}-0.2 \\
(-0.56)\end{array}$ & $\begin{array}{c}0.011 \\
(0.00)\end{array}$ \\
\hline Belgium & $\begin{array}{c}-0.110 \\
(-1.85)\end{array}$ & $\begin{array}{c}9.0 \\
(0.98)\end{array}$ & $\begin{array}{c}-4.0 \\
(-1.38)\end{array}$ & $\begin{array}{l}-0.6^{* *} \\
(-3.23)\end{array}$ & $\begin{array}{l}-1.3^{* *} \\
(-2.61)\end{array}$ & $\begin{array}{c}-0.1 \\
(-0.30)\end{array}$ & $\begin{array}{r}0.016 \\
(0.00)\end{array}$ \\
\hline Germany & $\begin{array}{l}-0.152 * \\
(-2.17)\end{array}$ & $\begin{array}{l}22.9 * \\
(2.12)\end{array}$ & $\begin{array}{c}-13.5 * * \\
(-3.51)\end{array}$ & $\begin{array}{c}-0.1 \\
(-0.64)\end{array}$ & $\begin{array}{c}-1.1 \\
(-1.70)\end{array}$ & $\begin{array}{c}0.0 \\
(0.08)\end{array}$ & $\begin{array}{r}0.010 \\
(0.08)\end{array}$ \\
\hline Austria & $\begin{array}{l}-0.116^{*} \\
(-2.30)\end{array}$ & $\begin{array}{c}4.9 \\
(0.63)\end{array}$ & $\begin{array}{c}1.7 \\
(0.62)\end{array}$ & $\begin{array}{c}-0.3^{*} \\
(-2.33)\end{array}$ & $\begin{array}{c}-0.8 \\
(-1.69)\end{array}$ & $\begin{array}{c}-0.2 \\
(-1.26)\end{array}$ & $\begin{array}{r}0.049 \\
(0.00)\end{array}$ \\
\hline Switzerland & $\begin{array}{c}-0.040 \\
(-0.68)\end{array}$ & $\begin{array}{l}15.4^{*} \\
(2.02)\end{array}$ & $\begin{array}{l}-9.6 * * \\
(-3.08)\end{array}$ & $\begin{array}{l}-0.4 * * \\
(-2.84)\end{array}$ & $\begin{array}{c}-0.5 \\
(-1.06)\end{array}$ & $\begin{array}{c}-0.3 \\
(-1.08)\end{array}$ & $\begin{array}{r}0.010 \\
(0.00)\end{array}$ \\
\hline France & $\begin{array}{c}-0.134 \\
(-1.95)\end{array}$ & $\begin{array}{c}11.1 \\
(1.17)\end{array}$ & $\begin{array}{c}-12.8^{* *} \\
(-3.77)\end{array}$ & $\begin{array}{l}-0.6^{* *} \\
(-2.85)\end{array}$ & $\begin{array}{l}-1.4^{*} \\
(-2.48)\end{array}$ & $\begin{array}{c}0.0 \\
(-0.23)\end{array}$ & $\begin{array}{r}0.011 \\
(0.01)\end{array}$ \\
\hline Canada & $\begin{array}{c}-0.074 \\
(-1.18)\end{array}$ & $\begin{array}{c}6.7 \\
(0.88)\end{array}$ & $\begin{array}{l}-9.1 * * \\
(-3.01)\end{array}$ & $\begin{array}{c}-0.1 \\
(-1.23)\end{array}$ & $\begin{array}{c}-0.2 \\
(-0.41)\end{array}$ & $\begin{array}{c}-0.1 \\
(-1.60)\end{array}$ & $\begin{array}{r}0.009 \\
(0.01)\end{array}$ \\
\hline Italy & $\begin{array}{c}-0.091 \\
(-1.16)\end{array}$ & $\begin{array}{c}4.5 \\
(0.50)\end{array}$ & $\begin{array}{c}-13.9 * * \\
(-3.47)\end{array}$ & $\begin{array}{l}-0.7 * * \\
(-3.03)\end{array}$ & $\begin{array}{c}0.0 \\
(0.01)\end{array}$ & $\begin{array}{c}0.3 \\
(1.11)\end{array}$ & $\begin{array}{r}0.020 \\
(0.00)\end{array}$ \\
\hline U.S. - DJIA & $\begin{array}{c}-0.078 \\
(-1.90)\end{array}$ & $\begin{array}{c}7.7 \\
(1.40)\end{array}$ & $\begin{array}{c}-10.5 * * \\
(-4.95)\end{array}$ & $\begin{array}{c}0.0 \\
(-0.58)\end{array}$ & $\begin{array}{l}-0.7^{*} \\
(-2.51)\end{array}$ & $\begin{array}{c}-0.3 \\
(-1.76)\end{array}$ & $\begin{array}{r}0.010 \\
(0.86)\end{array}$ \\
\hline U.S. - S\&P500 & $\begin{array}{c}-0.053 \\
(-1.28)\end{array}$ & $\begin{array}{c}2.2 \\
(0.39)\end{array}$ & $\begin{array}{c}-15.0 * * \\
(-6.99)\end{array}$ & $\begin{array}{c}-0.1 \\
(-1.40)\end{array}$ & $\begin{array}{l}-0.8^{* *} \\
(-2.61)\end{array}$ & $\begin{array}{c}-0.1 \\
(-0.58)\end{array}$ & $\begin{array}{r}0.010 \\
(0.34)\end{array}$ \\
\hline U.S. - ewAMEX & $\begin{array}{r}-0.060 \\
(-1.64)\end{array}$ & $\begin{array}{l}53.4^{* *} \\
(7.53)\end{array}$ & $\begin{array}{l}-33.0 * * \\
(-16.42)\end{array}$ & $\begin{array}{l}-0.2^{* *} \\
(-2.70)\end{array}$ & $\begin{array}{l}-0.7 * * \\
(-2.73)\end{array}$ & $\begin{array}{c}-0.1 \\
(-0.81)\end{array}$ & $\begin{array}{c}0.174 \\
(0.00)\end{array}$ \\
\hline U.S. - ewNASD & $\begin{array}{r}-0.064 \\
(-1.40)\end{array}$ & $\begin{array}{c}35.5^{* *} \\
(5.49)\end{array}$ & $\begin{array}{l}-31.2^{* *} \\
(-13.80)\end{array}$ & $\begin{array}{c}-0.2^{*} \\
(-2.54)\end{array}$ & $\begin{array}{c}-0.6^{*} \\
(-2.03)\end{array}$ & $\begin{array}{c}0.0 \\
(-0.17)\end{array}$ & $\begin{array}{r}0.102 \\
(0.00)\end{array}$ \\
\hline U.S. - ewNYSE & $\begin{array}{c}-0.080^{*} \\
(-2.19) \\
\end{array}$ & $\begin{array}{l}25.0^{* *} \\
(4.74) \\
\end{array}$ & $\begin{array}{l}-23.0 * * \\
(-12.00) \\
\end{array}$ & $\begin{array}{c}-0.2^{*} \\
(-2.38) \\
\end{array}$ & $\begin{array}{l}-0.8^{* *} \\
(-3.12) \\
\end{array}$ & $\begin{array}{c}0.0 \\
(-0.22) \\
\end{array}$ & $\begin{array}{r}0.050 \\
(0.00) \\
\end{array}$ \\
\hline
\end{tabular}


Patrick J. Kelly, Felix Meschke, Sentiment and stock returns: The SAD anomaly revisited, Journal of Banking \& Finance, June 2010, Volume 34.6:1308-1326. Publisher's official version: http://dx.doi.org/10.1016/j.jbankfin.2009.11.027. Open Access version: http://kuscholarworks.ku.edu/dspace/.

\begin{tabular}{|c|c|c|c|c|c|c|c|}
\hline Country & $\begin{array}{c}\text { Onset/ } \\
\text { Recovery }\end{array}$ & Tax & Monday & Temp & Cloud & Precip. & RSQ \\
\hline U.S. - vwAMEX & $\begin{array}{c}-0.050 \\
(-1.11)\end{array}$ & $\begin{array}{l}19.9 * * \\
(3.07)\end{array}$ & $\begin{array}{l}-28.6^{* *} \\
(-12.17)\end{array}$ & $\begin{array}{c}-0.2^{*} \\
(-2.41)\end{array}$ & $\begin{array}{c}-0.7^{*} \\
(-2.21)\end{array}$ & $\begin{array}{c}0.0 \\
(-0.11)\end{array}$ & $\begin{array}{r}0.072 \\
(0.00)\end{array}$ \\
\hline U.S. - vwNASD & $\begin{array}{c}-0.038 \\
(-0.52)\end{array}$ & $\begin{array}{c}16.7 \\
(1.37)\end{array}$ & $\begin{array}{l}-21.8 * * \\
(-6.10)\end{array}$ & $\begin{array}{c}-0.2 \\
(-1.11)\end{array}$ & $\begin{array}{c}-1.0 \\
(-1.96)\end{array}$ & $\begin{array}{c}0.1 \\
(0.24)\end{array}$ & $\begin{array}{r}0.012 \\
(0.01)\end{array}$ \\
\hline U.S. - vwNYSE & $\begin{array}{c}-0.055 \\
(-1.42)\end{array}$ & $\begin{array}{c}2.7 \\
(0.53)\end{array}$ & $\begin{array}{c}-16.0 * * \\
(-7.96)\end{array}$ & $\begin{array}{c}-0.1 \\
(-1.72)\end{array}$ & $\begin{array}{l}-0.7 * * \\
(-2.73)\end{array}$ & $\begin{array}{c}-0.1 \\
(-0.70)\end{array}$ & $\begin{array}{r}0.017 \\
(0.40)\end{array}$ \\
\hline China & $\begin{array}{l}-0.175 \\
(-0.80)\end{array}$ & $\begin{array}{c}39.0 \\
(1.72)\end{array}$ & $\begin{array}{l}-16.4 \\
(-1.28)\end{array}$ & $\begin{array}{c}0.1 \\
(0.17)\end{array}$ & $\begin{array}{c}1.2 \\
(0.80)\end{array}$ & $\begin{array}{c}0.2 \\
(0.22)\end{array}$ & $\begin{array}{c}0.004 \\
(0.00)\end{array}$ \\
\hline Spain & $\begin{array}{r}-0.127 \\
(-1.72)\end{array}$ & $\begin{array}{c}11.7 \\
(1.28)\end{array}$ & $\begin{array}{c}7.9 \\
(1.87)\end{array}$ & $\begin{array}{c}-0.5^{*} \\
(-2.26)\end{array}$ & $\begin{array}{c}-0.6 \\
(-1.20)\end{array}$ & $\begin{array}{c}0.2 \\
(1.40)\end{array}$ & $\begin{array}{r}0.016 \\
(0.00)\end{array}$ \\
\hline Greece & $\begin{array}{c}-0.243 \\
(-1.70)\end{array}$ & $\begin{array}{l}47.2 * * \\
(2.87)\end{array}$ & $\begin{array}{l}-17.1^{*} \\
(-2.31)\end{array}$ & $\begin{array}{c}0.2 \\
(0.56)\end{array}$ & $\begin{array}{c}1.5 \\
(1.30)\end{array}$ & $\begin{array}{c}1.0 \\
(1.31)\end{array}$ & $\begin{array}{r}0.031 \\
(0.35)\end{array}$ \\
\hline Turkey & $\begin{array}{c}0.259 \\
(1.28)\end{array}$ & $\begin{array}{c}50.3 \\
(1.73)\end{array}$ & $\begin{array}{c}-30.7 * * \\
(-2.98)\end{array}$ & $\begin{array}{c}-0.9 \\
(-1.46)\end{array}$ & $\begin{array}{c}0.4 \\
(0.23)\end{array}$ & $\begin{array}{c}-1.1 \\
(-1.22)\end{array}$ & $\begin{array}{r}0.012 \\
(0.13)\end{array}$ \\
\hline Korea & $\begin{array}{c}0.002 \\
(0.02)\end{array}$ & $\begin{array}{c}-7.6 \\
(-0.38)\end{array}$ & $\begin{array}{c}3.1 \\
(0.56)\end{array}$ & $\begin{array}{c}-0.3 \\
(-1.28)\end{array}$ & $\begin{array}{c}-0.4 \\
(-0.49)\end{array}$ & $\begin{array}{c}0.1 \\
(1.54)\end{array}$ & $\begin{array}{r}0.007 \\
(0.00)\end{array}$ \\
\hline Japan & $\begin{array}{c}-0.073 \\
(-0.94)\end{array}$ & $\begin{array}{c}1.4 \\
(0.16)\end{array}$ & $\begin{array}{c}-5.5 \\
(-1.57)\end{array}$ & $\begin{array}{c}-0.2 \\
(-0.85)\end{array}$ & $\begin{array}{l}-1.2^{*} \\
(-2.34)\end{array}$ & $\begin{array}{c}-0.2 \\
(-1.02)\end{array}$ & $\begin{array}{c}0.004 \\
(0.01)\end{array}$ \\
\hline Jordan & $\begin{array}{c}0.045 \\
(0.46)\end{array}$ & $\begin{array}{l}38.6 * * \\
(2.96)\end{array}$ & $\begin{array}{c}2.6 \\
(0.49)\end{array}$ & $\begin{array}{c}0.1 \\
(0.36)\end{array}$ & $\begin{array}{c}1.4 \\
(1.38)\end{array}$ & $\begin{array}{c}0.1 \\
(0.14)\end{array}$ & $\begin{array}{c}0.021 \\
(0.02)\end{array}$ \\
\hline Mexico & $\begin{array}{l}-0.240 \\
(-1.66)\end{array}$ & $\begin{array}{c}0.7 \\
(0.03)\end{array}$ & $\begin{array}{c}1.0 \\
(0.15)\end{array}$ & $\begin{array}{c}-0.7 \\
(-0.82)\end{array}$ & $\begin{array}{c}-0.1 \\
(-0.05)\end{array}$ & $\begin{array}{c}0.9 \\
(0.82)\end{array}$ & $\begin{array}{c}0.032 \\
(0.01)\end{array}$ \\
\hline Taiwan & $\begin{array}{l}-0.170 \\
(-1.22)\end{array}$ & $\begin{array}{c}30.5 \\
(1.68)\end{array}$ & $\begin{array}{c}9.5 \\
(1.19)\end{array}$ & $\begin{array}{c}-0.8 \\
(-1.46)\end{array}$ & $\begin{array}{c}-2.2 \\
(-1.66)\end{array}$ & $\begin{array}{c}0.0 \\
(0.17)\end{array}$ & $\begin{array}{r}0.010 \\
(0.11)\end{array}$ \\
\hline Hong Kong & $\begin{array}{c}-0.024 \\
(-0.19)\end{array}$ & $\begin{array}{c}-11.1 \\
(-0.87)\end{array}$ & $\begin{array}{l}-15.9 * \\
(-2.37)\end{array}$ & $\begin{array}{c}-0.9 * \\
(-1.97)\end{array}$ & $\begin{array}{c}-0.6 \\
(-0.66)\end{array}$ & $\begin{array}{c}-0.1 \\
(-1.05)\end{array}$ & $\begin{array}{r}0.007 \\
(0.00)\end{array}$ \\
\hline India & $\begin{array}{c}-0.038 \\
(-0.23)\end{array}$ & $\begin{array}{c}18.7 \\
(0.86)\end{array}$ & $\begin{array}{c}6.9 \\
(0.88)\end{array}$ & $\begin{array}{c}-1.5 \\
(-1.16)\end{array}$ & $\begin{array}{c}0.4 \\
(0.34)\end{array}$ & $\begin{array}{c}0.1 \\
(0.32)\end{array}$ & $\begin{array}{r}0.015 \\
(0.39)\end{array}$ \\
\hline Thailand & $\begin{array}{c}-0.022 \\
(-0.26)\end{array}$ & $\begin{array}{l}24.5 \\
(1.74)\end{array}$ & $\begin{array}{c}-30.1^{* *} \\
(-6.15)\end{array}$ & $\begin{array}{c}-1.5 \\
(-1.51)\end{array}$ & $\begin{array}{c}0.7 \\
(0.55)\end{array}$ & $\begin{array}{c}-0.2 \\
(-1.25)\end{array}$ & $\begin{array}{c}0.035 \\
(0.35)\end{array}$ \\
\hline Philippines & $\begin{array}{c}-0.149 \\
(-1.11)\end{array}$ & $\begin{array}{c}16.4 \\
(0.82)\end{array}$ & $\begin{array}{l}-14.9 * \\
(-2.08)\end{array}$ & $\begin{array}{c}-2.5 \\
(-1.74)\end{array}$ & $\begin{array}{c}-3.0 \\
(-1.35)\end{array}$ & $\begin{array}{c}0.3 \\
(0.85)\end{array}$ & $\begin{array}{r}0.032 \\
(0.07)\end{array}$ \\
\hline Sri Lanka & $\begin{array}{c}-0.029 \\
(-0.29)\end{array}$ & $\begin{array}{c}2.3 \\
(0.17)\end{array}$ & $\begin{array}{c}-0.7 \\
(-0.16)\end{array}$ & $\begin{array}{c}-1.0 \\
(-1.16)\end{array}$ & $\begin{array}{c}-2.2^{*} \\
(-2.20)\end{array}$ & $\begin{array}{c}0.2 \\
(1.22)\end{array}$ & $\begin{array}{c}0.181 \\
(0.89)\end{array}$ \\
\hline Malaysia & $\begin{array}{c}-0.053 \\
(-0.59)\end{array}$ & $\begin{array}{c}2.5 \\
(0.22)\end{array}$ & $\begin{array}{c}-22.0 * * \\
(-4.60)\end{array}$ & $\begin{array}{c}1.4 \\
(0.72)\end{array}$ & $\begin{array}{c}-5.8 \\
(-1.11)\end{array}$ & $\begin{array}{c}-0.4 \\
(-1.63)\end{array}$ & $\begin{array}{c}0.018 \\
(0.11)\end{array}$ \\
\hline Singapore & $\begin{array}{c}-0.103 \\
(-1.47)\end{array}$ & $\begin{array}{c}29.2^{* *} \\
(2.86)\end{array}$ & $\begin{array}{c}-16.9 * * \\
(-4.02)\end{array}$ & $\begin{array}{c}-0.9 \\
(-0.84)\end{array}$ & $\begin{array}{c}-2.1 \\
(-1.07)\end{array}$ & $\begin{array}{c}-0.2 \\
(-1.48)\end{array}$ & $\begin{array}{r}0.014 \\
(0.01)\end{array}$ \\
\hline Indonesia & $\begin{array}{c}-0.115 \\
(-1.17)\end{array}$ & $\begin{array}{c}3.8 \\
(0.24)\end{array}$ & $\begin{array}{l}-10.0 \\
(-1.75)\end{array}$ & $\begin{array}{c}-0.7 \\
(-0.76)\end{array}$ & $\begin{array}{c}0.8 \\
(0.46)\end{array}$ & $\begin{array}{c}-0.4^{*} \\
(-2.57)\end{array}$ & $\begin{array}{r}0.090 \\
(0.00)\end{array}$ \\
\hline South Africa & $\begin{array}{c}-0.031 \\
(-0.42)\end{array}$ & $\begin{array}{c}-6.2 \\
(-0.61)\end{array}$ & $\begin{array}{c}-10.4^{* *} \\
(-2.65)\end{array}$ & $\begin{array}{c}0.5 \\
(1.40)\end{array}$ & $\begin{array}{c}-0.1 \\
(-0.24)\end{array}$ & $\begin{array}{c}-0.1 \\
(-0.81)\end{array}$ & $\begin{array}{c}0.014 \\
(0.05)\end{array}$ \\
\hline Australia & -0.116 & 10.2 & 0.1 & 0.1 & $-1.3^{*}$ & -0.2 & 0.010 \\
\hline All Ordinaries & $(-1.91)$ & $(1.55)$ & $(0.04)$ & $(0.21)$ & $(-2.47)$ & $(-1.17)$ & $(0.00)$ \\
\hline Australia & -0.090 & 12.3 & -2.9 & 0.4 & -0.9 & -0.3 & 0.016 \\
\hline Total Market & $\begin{array}{l}(-1.47) \\
-0.039\end{array}$ & $\begin{array}{c}(1.96) \\
140\end{array}$ & $\begin{array}{l}(-0.93) \\
-127^{*}\end{array}$ & (1.59) & $(-1.79)$ & $(-1.76)$ & $\begin{array}{r}(0.00) \\
0.004\end{array}$ \\
\hline $\begin{array}{l}\text { New Zealand } \\
\text { Capital } 40\end{array}$ & $\begin{array}{c}-0.039 \\
(-0.35)\end{array}$ & $\begin{array}{c}14.0 \\
(0.91)\end{array}$ & $\begin{array}{l}-12.7^{*} \\
(-2.51)\end{array}$ & $\begin{array}{c}0.0 \\
(-0.01)\end{array}$ & $\begin{array}{c}-0.1 \\
(-0.06)\end{array}$ & $\begin{array}{c}0.0 \\
(0.03)\end{array}$ & $(0.41)$ \\
\hline $\begin{array}{l}\text { New Zealand } \\
\text { FTSE }\end{array}$ & $\begin{array}{r}0.055 \\
(0.53)\end{array}$ & $\begin{array}{l}28.9^{*} \\
(2.36)\end{array}$ & $\begin{array}{c}-9.6^{*} \\
(-2.13)\end{array}$ & $\begin{array}{c}0.3 \\
(0.38)\end{array}$ & $\begin{array}{c}0.1 \\
(0.05)\end{array}$ & $\begin{array}{c}0.0 \\
(0.29)\end{array}$ & $\begin{array}{r}0.003 \\
(0.23)\end{array}$ \\
\hline
\end{tabular}

* Significant at the two-sided 5 percent level

** Significant at the two-sided 1 percent level 
Table 8

Daily return regression on the fall dummy, SAD measure, and weather controls for each year. This table reports results from annual regressions of Equation 1 for each index with at least 125 daily observations. For brevity the table reports the percentage of years where the fall and SAD coefficients are positive and significant, positive and insignificant, negative and insignificant and negative and significant at alpha $=0.05$. t-stats used to determine significance control for heteroskedasticity following MacKinnon and White (1985).

\begin{tabular}{|c|c|c|c|c|c|c|c|c|}
\hline \multirow[b]{3}{*}{ Country } & \multicolumn{4}{|c|}{ Fall } & \multicolumn{4}{|c|}{ SAD } \\
\hline & \multicolumn{2}{|c|}{ Negative } & \multicolumn{2}{|c|}{ Positive } & \multicolumn{2}{|c|}{ Negative } & \multicolumn{2}{|c|}{ Positive } \\
\hline & Sig. & Insig. & Sig. & Insig. & Sig. & Insig. & Sig. & Insig. \\
\hline Finland & 0 & 61 & 6 & 33 & 0 & 39 & 6 & 56 \\
\hline Iceland & 20 & 53 & 7 & 20 & 0 & 40 & 13 & 47 \\
\hline Norway & 10 & 52 & 0 & 38 & 0 & 45 & 7 & 48 \\
\hline Sweden - OMX & 9 & 50 & 0 & 41 & 5 & 23 & 0 & 73 \\
\hline Sweden - Veckans Aff. & 12 & 53 & 0 & 35 & 6 & 18 & 0 & 76 \\
\hline Denmark & 0 & 63 & 0 & 37 & 0 & 21 & 5 & 74 \\
\hline Ireland & 3 & 69 & 0 & 29 & 0 & 26 & 11 & 63 \\
\hline Netherlands & 0 & 64 & 0 & 36 & 0 & 50 & 6 & 44 \\
\hline U.K. FTSE 100 & 12 & 40 & 0 & 48 & 0 & 32 & 8 & 60 \\
\hline U.K. - Tot. Mkt. & 11 & 58 & 0 & 31 & 3 & 33 & 6 & 58 \\
\hline Belgium & 9 & 60 & 0 & 31 & 0 & 34 & 9 & 57 \\
\hline Germany & 4 & 62 & 0 & 35 & 0 & 35 & 4 & 62 \\
\hline Austria & 3 & 63 & 7 & 27 & 0 & 33 & 3 & 63 \\
\hline Switzerland & 3 & 52 & 3 & 42 & 0 & 39 & 9 & 52 \\
\hline France & 6 & 53 & 0 & 42 & 3 & 39 & 0 & 58 \\
\hline Canada & 7 & 41 & 0 & 52 & 3 & 28 & 14 & 55 \\
\hline Italy & 6 & 64 & 0 & 31 & 0 & 31 & 17 & 53 \\
\hline U.S. - DJIA & 4 & 56 & 5 & 35 & 2 & 37 & 2 & 60 \\
\hline U.S. - S\&P500 & 4 & 47 & 4 & 46 & 2 & 28 & 4 & 67 \\
\hline U.S. - ewAMEX & 30 & 44 & 2 & 23 & 2 & 40 & 21 & 37 \\
\hline U.S. - ewNASD & 27 & 45 & 0 & 27 & 3 & 36 & 12 & 48 \\
\hline U.S. - ewNYSE & 11 & 49 & 5 & 35 & 2 & 32 & 12 & 54 \\
\hline U.S. - vWAMEX & 9 & 60 & 0 & 30 & 2 & 35 & 14 & 49 \\
\hline U.S. - vwNASD & 9 & 48 & 0 & 42 & 0 & 30 & 12 & 58 \\
\hline U.S. - vwNYSE & 4 & 53 & 4 & 40 & 2 & 32 & 5 & 61 \\
\hline China & 8 & 62 & 0 & 31 & 0 & 62 & 0 & 38 \\
\hline Spain & 8 & 46 & 0 & 46 & 0 & 46 & 0 & 54 \\
\hline Greece & 5 & 60 & 0 & 35 & 0 & 35 & 10 & 55 \\
\hline Turkey & 5 & 52 & 5 & 38 & 0 & 29 & 14 & 57 \\
\hline Korea & 3 & 47 & 7 & 43 & 3 & 40 & 7 & 50 \\
\hline Japan & 0 & 69 & 0 & 31 & 0 & 56 & 0 & 44 \\
\hline Jordan & 25 & 50 & 0 & 25 & 0 & 0 & 25 & 75 \\
\hline Mexico & 13 & 47 & 7 & 33 & 0 & 33 & 7 & 60 \\
\hline Taiwan & 5 & 60 & 0 & 35 & 0 & 30 & 5 & 65 \\
\hline Hong Kong & 3 & 62 & 0 & 34 & 0 & 38 & 14 & 48 \\
\hline India & 15 & 31 & 8 & 46 & 0 & 31 & 23 & 46 \\
\hline Thailand & 0 & 50 & 4 & 46 & 4 & 54 & 0 & 43 \\
\hline Philippines & 6 & 50 & 0 & 44 & 0 & 39 & 11 & 50 \\
\hline Sri Lanka & - & - & - & - & - & - & - & - \\
\hline Malaysia & 4 & 46 & 0 & 50 & 0 & 39 & 4 & 57 \\
\hline Singapore & 6 & 36 & 6 & 52 & 9 & 39 & 3 & 48 \\
\hline Indonesia & 6 & 22 & 17 & 56 & 17 & 44 & 6 & 33 \\
\hline South Africa & 7 & 39 & 0 & 54 & 0 & 36 & 4 & 61 \\
\hline Australia-All Ordinaries & 0 & 48 & 0 & 52 & 3 & 52 & 0 & 45 \\
\hline Australia -Total Market & 0 & 44 & 0 & 56 & 3 & 59 & 3 & 35 \\
\hline New Zealand Capital 40 & 0 & 63 & 0 & 38 & 0 & 50 & 0 & 50 \\
\hline New Zealand - FTSE & 8 & 58 & 0 & 33 & 0 & 58 & 8 & 33 \\
\hline All Indices & 8 & 52 & 2 & 38 & 2 & 36 & 8 & 54 \\
\hline
\end{tabular}

